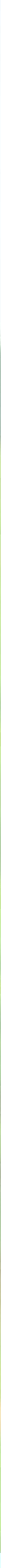

Bouwstenen voor beleidsontwikkeling Agrofood Noord-Brabant 2040

Theun Vellinga, Frederike Praasterink, Pieter de Wolf, Davide Angelucci, Lauren Verheijen en

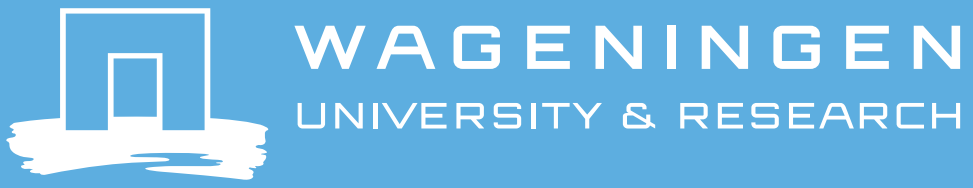





\section{Bouwstenen voor beleidsontwikkeling Agrofood Noord-Brabant 2040}

Theun Vellinga ${ }^{1}$

Frederike Praasterink ${ }^{2}$

Pieter de Wolf ${ }^{3}$

Davide Angelucci ${ }^{1}$

Lauren Verheijen ${ }^{2}$

Fien van Cappellen ${ }^{2}$

1 Wageningen Livestock Research (WLR)

2 HAS Hogeschool

3 Wageningen Plant Research (WPR)

Dit onderzoek is uitgevoerd door Wageningen Research en HAS Hogeschool 
Vellinga, T., F. Praasterink, PL. De Wolf, D. Angelucci, L. Verheijen, F. van Cappellen, 2021. Landbouw en voedsel in Noord-Brabant, bouwstenen voor een visie. Wageningen Livestock Research, HAS Hogeschool, Wageningen Plant Research. Rapport 1282.

Samenvatting NL Dit rapport, gemaakt in opdracht van de Provincie Noord-Brabant, geeft een beschrijving van het huidige voedselsysteem en een aantal (maatschappelijke) ontwikkelingen in Noord-Brabant en aandachtspunten daaruit volgen die bij visievorming en beleidsontwikkeling over de agrofood sector in Noord-Brabant relevant zijn.

Summery UK This report, commissioned by the Province of Noord-Brabant, provides a description of the current food system and a number of (social) developments in Noord-Brabant and points for attention that are relevant to vision formation and policy development about the agri-food sector in Noord-Brabant.

Dit rapport is gratis te downloaden op https://doi.org/10.18174/535951 of op www.wur.nl/livestock-research (onder Wageningen Livestock Research publicaties).

\section{(c) BY-NC}

Dit werk valt onder een Creative Commons Naamsvermelding-Niet Commercieel 4.0 Internationaallicentie.

(C) Wageningen Livestock Research, onderdeel van Stichting Wageningen Research, 2021

De gebruiker mag het werk kopiëren, verspreiden en doorgeven en afgeleide werken maken. Materiaal van derden waarvan in het werk gebruik is gemaakt en waarop intellectuele eigendomsrechten berusten, mogen niet zonder voorafgaande toestemming van derden gebruikt worden. De gebruiker dient bij het werk de door de maker of de licentiegever aangegeven naam te vermelden, maar niet zodanig dat de indruk gewekt wordt dat zij daarmee instemmen met het werk van de gebruiker of het gebruik van het werk. De gebruiker mag het werk niet voor commerciële doeleinden gebruiken.

Wageningen Livestock Research aanvaardt geen aansprakelijkheid voor eventuele schade voortvloeiend uit het gebruik van de resultaten van dit onderzoek of de toepassing van de adviezen.

Wageningen Livestock Research is NEN-EN-ISO 9001:2015 gecertificeerd.

Op al onze onderzoeksopdrachten zijn de Algemene Voorwaarden van de Animal Sciences Group van toepassing. Deze zijn gedeponeerd bij de Arrondissementsrechtbank Zwolle. 


\section{Inhoudsopgave}

$\begin{array}{ll}\text { Inhoudsopgave } & \mathbf{3}\end{array}$

$\begin{array}{ll}\text { Woord vooraf } & \mathbf{5}\end{array}$

$\begin{array}{lr}\text { Samenvatting } & 7\end{array}$

$1 \quad$ Inleiding

1.1 Aanleiding: behoefte aan een gedragen toekomstplan voor landbouw en voedsel in Noord-Brabant

$\begin{array}{lll}1.2 & \text { Doel: onderbouwde input voor visievorming } & 15\end{array}$

2.1 Het verloop van het project 16

2.2 Inhoudelijke werkwijze $\quad 16$

2.2.1 Voedselsysteembeschrijving 16

2.2.2 Kijken naar drie ruimtelijke niveaus $\quad 17$

$\begin{array}{ll}2.2 .3 \text { Toekomstverkenning } & 18\end{array}$

3 De huidige situatie Noord-Brabant $r$

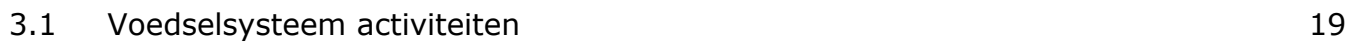

3.1.1 De primaire productie 19

$\begin{array}{ll}3.1 .2 \text { Biologische landbouw } & 22\end{array}$

$\begin{array}{ll}3.1 .3 \text { Voedselverwerking en handel } & 23\end{array}$

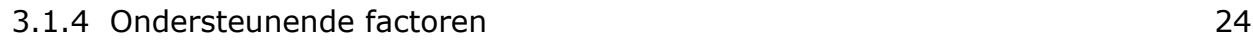

3.1.5 Samenvatting voedselsysteemactiviteiten. 24

3.2 Sociaaleconomische factoren $\quad 25$

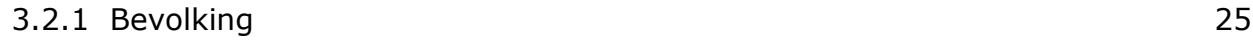

3.2.2 Productie en consumptie internationaal verknoopt 28

3.2.3 Marktontwikkelingen $\quad 29$

3.2.4 Wetenschap en and technologie $\quad 29$

3.2.5 Beleid 30

3.2.6 Samenvatting Sociaal economische factoren 31

$\begin{array}{lll}3.3 & \text { Omgevingsfactoren } & 31\end{array}$

3.3.1 Mineralen 31

3.3.2 Biodiversiteit 34

3.3.3 Land en bodem $\quad 36$

3.3.4 Water 38

3.3.5 Samenvatting omgevingsfactoren $\quad 40$

$\begin{array}{lll}3.4 & \text { Voedselsysteem resultaten } & 40\end{array}$

3.4.1 Voedselzekerheid 40

3.4.2 Volksgezondheid en voeding $\quad 41$

3.4.3 Overige effecten volksgezondheid $\quad 42$

3.4.4 Samenvatting voedselsysteemresultaten $\quad 42$

4.1 Mondiale en Nederlandse maatschappelijke opgaven 44

4.2 Transitieopgaven productie en consumptie 45

4.3 Opgavegerichte innovatie vergt ander beleid 46 
5.1 Voedselsysteem activiteiten $\quad 50$

5.1.1 De keten van productie en consumptie $\quad 50$

5.1.2 Landbouw $\quad 50$

5.1.3 Samenvatting voedselsysteemactiviteiten $\quad 52$

5.2 Sociaaleconomische factoren $\quad 53$

5.2.1 De vraag naar grond $\quad 53$

5.2.2 Marktontwikkelingen $\quad 54$

5.2.3 Internationale verbindingen $\quad 54$

5.2.4 Consumenten ontwikkelingen $\quad 55$

5.2.5 Samenvatting sociaaleconomische factoren 60

$\begin{array}{lll}5.3 \text { Milieufactoren } & 60\end{array}$

5.3.1 Klimaatverandering 60

$\begin{array}{ll}5.3 .2 \text { Biodiversiteit } & 62\end{array}$

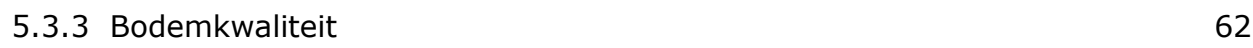

$\begin{array}{ll}\text { 5.3.4 Samenvatting milieufactoren } & 63\end{array}$

$\begin{array}{ll}\text { Kringlooplandbouw in Brabant } & 64\end{array}$

6.1 Enkele reflecties op het streven naar kringlooplandbouw $\quad 64$

6.1.1 Wat is het doel van kringlooplandbouw? $\quad 64$

6.1.2 Plantaardig boven dierlijk voedsel $\quad 65$

$\begin{array}{ll}6.1 .3 & \text { Inzet van reststromen }\end{array}$

6.1.4 Gebruik dieren waar ze goed in zijn $\quad 65$

6.1.5 Schaalniveaus in de kringloop 66

6.1.6 De schakels in de kringloop 66

6.1.7 Bespiegelingen over een circulair landbouwvoedselsysteem 67

$\begin{array}{ll}6.1 .8 & \text { Samenvatting }\end{array}$

6.2 Een blik vooruit: voedselvoorziening in Noordwest Europa 68

$\begin{array}{lll}\text { 6.2.1 Het huidige en toekomstige dieet } & 68\end{array}$

6.2.2 Productie en handel in Noordwest Europa 70

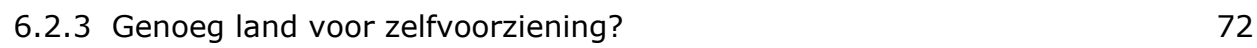

$\begin{array}{ll}\text { 6.2.4 Samenvatting } & 74\end{array}$ 


\section{Woord vooraf}

Landbouw en voedsel zijn belangrijke maatschappelijke thema's, waar veel mensen zich bij betrokken voelen. Het is daarom begrijpelijk dat de provincie Noord-Brabant, vanuit het nieuwe bestuursakkoord, een visie- en beleidsontwikkelingsproces is gestart voor het provinciale landbouwvoedselsysteem voor de toekomst. Daarin worden allerlei mensen en organisaties betrokken, die hun visie, idealen, wensen en belangen inbrengen. Daarnaast is de WUR met HAS Hogeschool gevraagd om een bijdrage te leveren met een feitelijke analyse van het landbouwvoedselsysteem en de relevante trends daaromheen.

We zijn dit project begonnen onder leiding van Theun Vellinga, die helaas het project door omstandigheden niet heeft kunnen afronden. Als medeauteurs hebben wij het rapport afgerond en de reacties van de opdrachtgever verwerkt. Hoewel dat altijd meer tijd kost dan voorzien, was het toch ook weer inspirerend om met deze materie bezig te zijn. Het is opvallend om te zien dat er enorm veel studies en data beschikbaar zijn om een goede en integrale analyse te maken, maar dat deze analyse vaak niet gemaakt wordt. Door het bij elkaar brengen en met elkaar doorspreken van al deze 'puzzelstukken' wordt mogelijk geen nieuwe kennis ontwikkeld, maar wel een beter inzicht verkregen om vervolgens beleid op te bouwen.

Een andere bevinding in dit project was dat er een gezonde spanning zit tussen realiteit en toekomstvisie. Deze spanning zal ook terugkomen in elk beleidsproces, zeker als er grote opgaven voorliggen. Dat is zeker in Noord-Brabant het geval. De uitdaging, ook voor ons, is dan steeds weer om enerzijds helder de opgaven en doelen voor de toekomst te schetsen, maar tegelijk ook de verbinding te maken met de huidige situatie. Als de toekomstvisie los komt te staan van de realiteit, blijft het bij een mooi verhaal zonder impact. Als de realiteit gaat domineren over de toekomst, blijft alles zoals het is of overvalt de verandering ons, omdat die door de omgeving wordt afgedwongen. En inhoudelijk hebben we geconstateerd dat het landbouw-voedselsysteem als geheel veel groter is dan de provincie Noord-Brabant, en zelfs de nationale schaal overstijgt. We hebben dus met elkaar een systeem gecreëerd, wat we nauwelijks meer kunnen sturen, maar wat wel grote invloed heeft op onze leefomgeving, onze gezondheid en onze economie. Met andere woorden: het gaat niet alleen, en misschien wel niet in de eerste plaats meer over landbouw en voedsel, maar over de governance vraag. Hoe krijgen we met elkaar weer grip op het landbouw-voedselsysteem, zodat het een grotere bijdrage gaat leveren aan de leefomgeving, de volksgezondheid en de economie van de provincie Noord-Brabant?

We willen onze opdrachtgever, dhr. Arie Meulepas van provincie Noord-Brabant danken voor de opdracht en voor de ruimte die we kregen om het rapport ver na de oorspronkelijke deadline af te ronden. We hopen dat het een goede basis vormt voor de beleidsontwikkeling van de provincie op het belangrijke domein van landbouw en voedsel.

Namens de auteurs, Frederike Praasterink Pieter de Wolf 


\section{Samenvatting}

\section{Aanleiding: behoefte aan bouwstenen voor visieontwikkeling op landbouw en voedsel}

In het kader van de ontwikkeling van een visie op landbouw en voedsel was er bij de Provincie NoordBrabant behoefte om de huidige situatie in beeld te brengen en een inschatting te maken van een aantal relevante ontwikkelingen tot 2040, als bouwstenen voor een nieuwe visie. Het agrofood systeem is complex, er zijn veel partijen bij betrokken en er spelen veel belangen. Daarnaast is het agrofood systeem sterk internationaal georganiseerd, en zelf ook weer gerelateerd aan andere domeinen als energie en water. Er spelen stevige maatschappelijke issues, zoals stikstof, die soms leiden tot polarisatie en er zijn veel perspectieven over de gewenste ontwikkelrichting van de agrofood sector. Maar Brabant heeft ook een innovatieve en ondernemende cultuur.

Dit rapport heeft als doel om te schetsen welke ontwikkelingen een rol spelen en welke aandachtspunten daaruit voortvloeien die bij visievorming over ontwikkelrichtingen van de agrofood sector in Noord Brabant relevant zijn. Dit wordt gedaan door een analyse van het huidige voedselsysteem (zie figuur 1.1) gevolgd door een schets van de relevante ontwikkelingen.

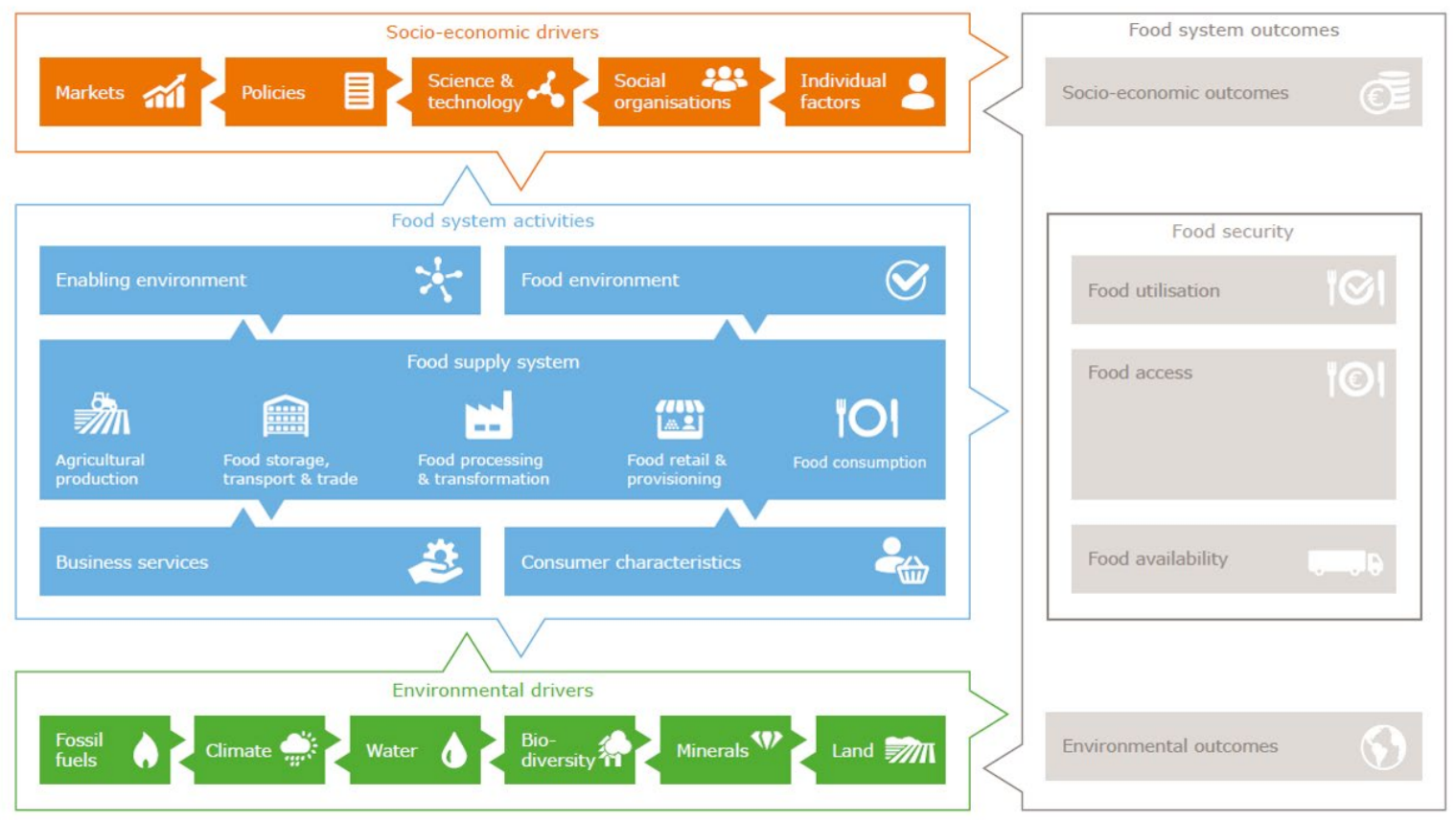

Figuur 1.1 Een voedselsysteem framewerk waarbij de voedselketen centraal staat en wordt beïnvloed door sociaaleconomische en milieukundige 'drivers'. Voedselsysteemactiviteiten leiden tot uitkomsten of resultaten (Van Berkum et al., 2018).

\section{Huidige voedselsysteem beschrijving}

\section{Voedselsysteem activiteiten}

De provincie Noord-Brabant is een van de belangrijkste landbouwgebieden in Nederland. Ze is verantwoordelijk voor $17,5 \%$ van het totale Nederlandse agrofood-export en $20 \%$ van Nederlandse agrofood productie. De toegevoegde waarde per hoofd van de bevolking is hoog, zeker in aanmerking nemend dat in Brabant slechts een beperkt deel van de mensen in de landbouw en aanpalende sectoren werkzaam is. Een van de belangrijke sectoren is de varkensvleesproductie, verantwoordelijk voor ongeveer 1 miljard euro per jaar (dit is het hoogste BBP vergeleken met de Noordwest Europa regio). Andere belangrijke landbouwsectoren in Brabant zijn sierplanten, bomen en bloemen, verse melk en verse groenten. Er is sprake van een zeer hoge standaard opbrengst van de landbouw, met name in het oosten van de provincie. 
De verschillende bedrijven die de hele voedselketen 'van grond tot mond' omvatten maken NoordBrabant tot een van de meest geconcentreerde gebieden van de wereld waar veel ketenspelers efficiënt samenwerken. Van oudsher zijn dit vaak coöperaties, die zich in de loop der jaren hebben ontwikkeld tot internationaal belangrijke spelers (Venema et al., 2019). Daarnaast is er een concentratie van varkenshouderij in met name het oosten van de provincie. Ook de melkvee-houderij is intensief ten opzichte van melkveehouderij elders in Nederland (Venema et al., 2019).

Het aandeel biologische landbouw in Noord-Brabant ligt onder het landelijk gemiddelde (in 2018 resp. 2.1 en $3.4 \%$ van het landbouwareaal; Venema et al., 2019). De strategische positie van Brabant tussen Rotterdam, Antwerpen en de Duitse stedelijke centra is een belangrijk voordeel.

Wat betreft de intensieve, niet-grondgebonden veehouderij is Brabant sterk afhankelijk van importen van (veevoer)grondstoffen van buiten Nederland, deels uit de EU en deels van buiten de EU.

\section{Sociaal economische factoren}

De bevolking van Brabant is aan het vergrijzen. Deze trend is echter niet sterker dan in Nederland of andere regio's in NWE (brabant.nl, CBS). Brabant is een verstedelijkte provincie, met een netwerk aan kleine en middelgrote steden (RIVM, 2020). De provincie Brabant kenmerkt zich door een hoge bevolkingsdichtheid en een hoge veedichtheid (FAOstat, Eurostat, 2020).

De voedselconsumptie is internationaal verknoopt. De consumptie van de Nederlandse burger is gemiddeld slechts voor een kwart afkomstig uit Nederland, de overige driekwart komt van buiten Nederland. Daarvan komt minder dan de helft van buiten de EU, met name de tropische producten, zoals fruit, cacao en rijst (PBL, 2019).

$\mathrm{Bij}$ de consumenten wordt ongeveer $80 \%$ thuis geconsumeerd, terwijl $20 \%$ buitenshuis wordt geconsumeerd. Deze cijfers zijn van vóór de coronacrisis. Het thuisbezorgen van maaltijden en maaltijdboxen uit korte ketens neemt toe; en nu juist extra vanwege de corona situatie,.

Hoewel de high-tech industrie niet primair op de landbouw is georiënteerd, is er wel sprake van een grote potentie van die industrie voor innovaties op technologisch gebied. Dit wordt gestimuleerd via diverse initiatieven; Brabant heeft bijvoorbeeld een precisielandbouw praktijkcentrum in Reusel.

Er is veel discussie over de rol van de landbouw, en met name de veehouderij met betrekking tot klimaat, milieu, biodiversiteit en volksgezondheid; er is een sterke polarisatie in het debat. Op dit moment is er sprake van actief beleid ten aanzien van de leefomgeving (inclusief volksgezondheid) als het gaat om stikstof, fosfaat en fijnstof; de biodiversiteit (Deltaplan Biodiversiteitsherstel), klimaat (Klimaatakkoord). Deels is dit nationaal beleid, deels provinciaal en deels gebiedsgericht (binnen de provincie, of over provinciegrenzen heen).

Landbouwbedrijven zijn vaak sterk gespecialiseerd op één product en één afzetmarkt en hebben vaak grote investeringen gedaan in één specifieke productiewijze. Daarom zijn ze niet in staat om snel in te spelen op veranderende marktvraag of nieuwe regelgeving. Daarnaast kunnen bedrijven moeilijk inspelen op maatschappelijke vragen, waar nog geen goed verdienmodel voor bestaat, zoals biodiversiteitsherstel en waterbeheer.

\section{Milieu- en Omgevingsfactoren}

De provincie Noord-Brabant heeft de hoogste veedichtheid in Noordwest Europa met 8.2 Livestock Units per hectare (Eurostat, 2019). Dit is ongeveer drie keer zoveel als het gemiddelde voor Noordwest Europa. De landbouw verantwoordelijk is voor bijna de helft van de stikstofdepositie in de provincie Brabant. De hoge veedichtheid zorgt niet alleen voor hoge emissies van N naar de lucht, ook de productie van $\mathrm{N}$ en $\mathrm{P}$ in dierlijke mest is hoog ten opzichte van het areaal, zowel op bedrijfs- als regionaal niveau. Deze vormen een bedreiging voor de biodiversiteit en de (drink)waterkwaliteit.

Noord-Brabant bezit in totaal zo'n 100000 hectare aan natuur- en recreatiegebieden (CBS, 2018b). Ondanks de grote inspanningen aan het einde van de 20 e eeuw om natuurgebieden in kwaliteit te verbeteren, te vergroten en met elkaar te verbinden, neemt de biodiversiteit nog steeds af (Brabant.nl). Brabant heeft de ambitie om in 2027 een aaneengesloten natuurnetwerk te hebben gerealiseerd om biodiversiteitsverlies te stoppen. Het gaat daarbij om circa 127000 ha natuur en 
$1500 \mathrm{~km}$ verbindingszones. Er komen echter 148 habitattypen, habitat en vogelrichtlijnsoorten voor waarvoor een resterende opgave geldt na 2027 . Dit is $79 \%$ van alle habitattypen en soorten die een opgave hebben in Nederland. Met name de kwaliteit van het leefgebied, of de structuur en functie zoals dit bij habitattypen wordt genoemd, dient verbeterd te worden. Daarnaast is er ook een resterende opgave m.b.t. uitbreiding van het leefgebied, zowel qua verspreiding als qua areaal.

Een groot deel van de landbouwgrond in Brabant is zand, dat vaak een beperkt waterbergend vermogen heeft en daarmee droogtegevoelig is. Ook is het gevoelig voor uitspoeling van nutriënten naar het grondwater. Water is daarom vaak een beperkende factor voor de productie. De droogteperiodes van de afgelopen jaren en de toename van de verdamping in het voorjaar in de afgelopen decennia leiden tot een groeiend tekort aan water. Zeker in regio's in Brabant waar op een aantal momenten in het jaar door watertekorten niet mag worden beregend uit oppervlaktewater kan dit tot productieverliezen in de landbouw leiden.

De productiviteit van de bodem wordt niet alleen beperkt door textuur en waterbeschikbaarheid, maar ook door de intensiteit van het grondgebruik: bodemverdichting en bodemziekten en -plagen vormen een bedreiging voor behoud of verbetering van de productiviteit. Dat geldt zowel op de zand- als de kleigronden. De zandgronden in het midden en oosten van Brabant kenmerken zich door een intensief bouwplan met akkerbouw-, tuinbouw- en ruwvoerteelten. Bodemverdichting en bodemziekten- en plagen vormen hier een grote uitdaging, evenals de waterhuishouding en de stikstofuitspoeling. De kleigronden in het westen van Brabant kennen een wat minder intensief bouwplan, hoewel ook met een relatief hoog aandeel rooivruchten. Bodemstructuur vormt hier de grootste uitdaging. Het verhogen van het organische stofgehalte om zo koolstof vast te leggen, kan leiden tot meer stikstofemissies, met name op uitspoelingsgevoelige zandgronden.

De overschotten aan mineralen door de concentratie van intensieve niet-grondgebonden veehouderij worden gereguleerd via nationale mestwetgeving. Mestverwerking brengt hoge kosten met zich mee. Het vinden van locaties voor mestverwerking (in het kader van ruimtelijke ordening) is moeilijk.

\section{Voedselsysteemresultaten}

Voedselsysteemresultaten, ofwel de uitkomsten van het voedselsysteem, kunnen worden geklusterd in sociaal-economische factoren, gezondheids- en milieufactoren.

Hoewel de agrofood sector in Brabant groot is en dus ook zorgt voor veel werkgelegenheid en economie, moet ook worden geconstateerd dat het huidige agrofood systeem maatschappelijke kosten heeft gerelateerd aan gezondheidskosten en milieukosten (bijv. kosten van de stikstofmaatregelen / stoppersregeling voor veehouders). Een recente schatting geeft aan dat de maatschappelijke kosten voor gezondheid, economie en milieu van het mondiale voedselsysteem 12 biljoen dollar bedragen; 20\% meer dan de marktwaarde ervan (Pharo et al, 2019). Voor Brabant, en voor Nederland zijn er geen cijfers.

Hoewel voedselzekerheid in Nederland nauwelijks een zorgpunt is, is wel sprake van een ongezond consumptiepatroon door Nederlanders. De helft van de volwassen Nederlanders is te zwaar, en heeft daardoor een grotere kans op gezondheidsproblemen. Ongezonde voeding is naar schatting van het RIVM verantwoordelijk voor ruim 8\% van de ziektelast in Nederland (RIVM, 2015), leidend tot 6 miljard euro aan zorgkosten per jaar. Voor Brabant zijn geen specifieke cijfers bekend maar aangenomen kan worden dat deze getallen niet afwijken van de cijfers op nationaal niveau.

De Brabanders zijn tevreden met hun woonomgeving, hoewel de scores m.b.t. huisvesting, kwaliteit van de leefomgeving en gezondheid lager zijn dan gemiddeld in Europa. De hoge veedichtheid leidt in een aantal gevallen tot problemen m.b.t. volksgezondheid, het gaat dan om luchtwegaandoeningen (RIVM, 2017). Daarnaast hebben zich incidenten voorgedaan met zoönosen, zoals de Q-koorts. Ook reductie van het gebruik van chemische bestrijdingsmiddelen krijgt meer aandacht.

Voor wat betreft de milieukundige resultaten (bodem, water, biodiversiteit, klimaat, etc): mondiaal gaat het agrofood systeem over vier planetaire grenzen heen: biodiversiteit, klimaat, nutriëntencycli, land- en watergebruik. Het Brabantse agrofood systeem is sterk verbonden met het Europese en mondiale agrofood systeem. Ook in Brabant speelt een aantal gerelateerde uitdagingen op het gebied 
van onder meer biodiversiteit, emissiereductie, klimaatdoelstellingen. Voor stikstof, bijvoorbeeld, is een reductieopgave vastgelegd in de Brabantse Ontwikkelaanpak Stikstof.

\section{Relevante ontwikkelingen}

\section{Maatschappelijke duurzaamheidsopgaven: redesign van het voedselsysteem?}

De landbouw- en voedsel sector in Nederland is een zeer innovatieve sector met een grote bijdrage aan onze economie. Tegelijkertijd zijn onze huidige voedselconsumptie en -productiepatronen sterk gerelateerd aan een aantal urgente en mondiale duurzaamheidsopgaven op het gebied van gezondheid en welzijn van mens, dier en planeet. Deze duurzaamheidsopgaven leiden tot grote maatschappelijke kosten; deze overtreffen mondiaal de economische baten. Deze maatschappelijke kosten worden nu nog veelal betaald door anderen (belastingbetalers, andere landen, volgende generaties). Ongezonde voeding, bijvoorbeeld, leidde tot 6 miljard euro aan zorgkosten per jaar in Nederland (RIVM, 2015);

Versnelde actie en radicale veranderingen in productie en consumptie, transities, zijn vereist om verdere milieudegradatie te stoppen, internationaal afgesproken doelen te halen en tegelijk ook de economische duurzaamheid van het landbouwvoedselsysteem te verbeteren. Een redesign van het voedselsysteem is ook vastgelegd in de Farm to Fork strategy die de EU momenteel ontwikkelt.

In Nederlandse kabinet positioneert maatschappelijke opgaven vooral als economische kansen voor bedrijven, o.a. in het missiegedreven Topsectorenbeleid waarin technologieontwikkeling en bedrijven centraal staan. Echter, impact op maatschappelijke opgaven vergt ook een ander type beleid. Dit beleid, gericht op transities, heeft een aantal karakteristieken:

- Het heeft een sterkere politieke lading om dat de maatschappelijke opgaven moeten worden gerealiseerd in een krachtenveld van uiteenlopende opvattingen, verwachtingen en (deel)belangen van bedrijven, onderzoekers, overheden en burgers (Rathenau, 2020).

- Het vergt een systeemaanpak waarin aandacht nodig voor de grondoorzaken van de maatschappelijke opgaven, en waar de synergiën van beleidsinterventies worden versterkt en de trade-offs worden gemanaged (OECD, 2021).

- Het vergt een transdisciplinaire aanpak waarbij gebruik wordt gemaakt van wetenschappelijke inzichten uit meerdere disciplines en de praktijkkennis van innovatieve ondernemers en nieuwe samenwerkingsplatforms (IPES Food, 2015)

In toenemende mate wordt een aantal maatschappelijke opgaven in Nederland geïntegreerd in een gebiedsgerichte aanpak. In zo'n gebiedsgerichte aanpak kunnen meerdere (transitie)agenda's worden gecombineerd, bijvoorbeeld op het gebied van stikstof- en klimaatdoelstellingen en duurzame energie, aansluitend bij de vele inspirerende voorbeelden van ondernemers en (bottom-up) duurzaamheidsinitiatieven en -coalities.

Gezien de omvang van de opgaven en de schaal waarop het landbouwvoedselsysteem is georganiseerd, is het wenselijk dat de provincie de samenwerking versterkt met andere regio's om transities te bevorderen. De provincie Noord-Brabant heeft in zo'n samenwerking veel te bieden, zoals een aantal grote ketenspelers, innovatieve ondernemers, samenwerkingsverbanden (bijv Agrofood Capital), proeftuinen (bijv Agroproeftuin de Peel) en kennispartijen. Tegelijk kan aansluiting gezocht worden bij o.a. Food Valley (Gelderland), Mineral Valley (Overijssel), Boerderij van de Toekomst (Flevoland), etc.

\section{Ontwikkelingen voedselsysteemactiviteiten}

Het gehele systeem van voedselproductie met de ketenpartijen die grondstoffen leveren en producten afnemen en de internationale oriëntatie zal in de toekomst blijven bestaan, mits de omvang van de primaire sector niet drastisch afneemt, bijvoorbeeld als gevolg van milieumaatregelen of ruimtelijk beleid.

Het aantal landbouwbedrijven zal nog afnemen door verdere schaalvergroting, en mogelijk ook onder druk van landelijk beleid (mestwetgeving, stikstofbeleid), waarbij veel bedrijfsgebouwen vrijkomen. Schaalvergroting (op economische schaal, dat kan in hectares, dieren, maar ook in omzet bij gelijke grootte) is de dominante trend om kosten te besparen. Druk op de sector leidt tot versnelde schaalvergroting (kleine bedrijven stoppen, grote bedrijven worden nog groter). Technologie zal een steeds grotere rol gaan spelen in de landbouw. Een deel van de bedrijven zal zich richten op het 
creëren van een grotere meerwaarde binnen de huidige bedrijfsgrootte via niches als biologische landbouw, korte ketens en nevenactiviteiten in bijvoorbeeld zorg of recreatie. In 2020 is dit aantal agrarische ondernemers in Brabant dat (een deel van) hun afzet via een korte keten (max 1 schakel tussen producent en consument) toegenomen tot 1.375 , oftewel $14,7 \%$ van de agrarische ondernemers (Venema et al, 2021, WEcR, nog te publiceren).

Energieproductie op land zal voor een deel ook op landbouwgrond gerealiseerd worden, de regie daarop ontbreekt grotendeels. De hoge grondprijzen zullen een stimulans blijven om de grond (zeer) intensief te gebruiken voor hoog salderende teelten die voor een deel in de non-food sector zitten. Er is waarschijnlijk weinig ruimte voor de teelt van bulkproducten. De economie van de primaire productie blijft een sterk sturende factor in het landgebruik.

\section{Ontwikkelingen sociaaleconomische factoren}

Vanwege de vraag naar grond voor o.a. woningen en duurzame energie (bijv zonnepanelen), de uitvoering van het natuurnetwerk Brabant en de bossenstrategie t.b.v. klimaatdoelstellingen zal het landbouwareaal afnemen. De productiviteit van het landbouwareaal staat onder druk door klimaatverandering, leidend tot toenemende droogte met name op de hoge zandgronden in Brabant. Dit kan leiden tot verdere afname van grond voor landbouwfuncties; inschatting van arealen zijn lastig te maken.

Marktontwikkelingen zijn onzeker. De verwachting is dat internationale handel, zowel export als import een belangrijke rol blijven vervullen in zowel de primaire productie als in de consumptie. Er is een toenemende behoefte aan transparantie in (internationale) productieketens.

De verbindingen met de stedelijke agglomeraties in de omgeving van Noord-Brabant worden verder ontwikkeld, via weg, spoor en door de lucht.

De verstedelijking en vergrijzing zullen doorzetten, in Nederland, maar ook in Noord-Brabant. De prognose is dat het percentage mensen in Noord-Brabant die buiten het actieve arbeidsproces zitten, aangegeven met 'groene druk' (mensen onder de 20 jaar) en 'grijze druk' (mensen boven de 65 jaar) de komende jaren zal stijgen naar respectievelijk 40 en 54\%.

(https://brabant.databank.nl/kiosken/index.html).

Er zal een beperkte bevolkingsgroei zijn, die voornamelijk afkomstig is van immigratie $\mathrm{Er}$ is sprake van een lichte verandering in consumptie naar meer gezonde voeding, naar lokale producten of meer duurzame producten. Hoewel consumenten aangeven dit belangrijk te vinden, is het aandeel van deze producten beperkt en wordt dit vooral gerealiseerd in hogere inkomensgroepen.

De maatschappelijke waardering voor de agri en food sectoren scoort bovengemiddeld ten opzichte van referentiesectoren als IT, energie, textiel. Akkerbouw en tuinbouw worden het meest positief gewaardeerd en de intensieve veehouderij het minst positief. Smaak, veilig, betaalbaar en gezond zijn (opnieuw) de belangrijkste voedselwaarden voor consumenten. De duurzaamheidswaarden scoren stabiel in de middenmoot. (Agrofood Monitor, 2020).

De afstand tussen boer en burger en de kennis van consumenten over de oorsprong van hun voedsel staan onder druk, onder andere door verdergaande verstedelijking en de complexiteit van het agrofood systeem. Daarnaast past de verdergaande industrialisering van de land- en tuinbouw niet bij het ideaalbeeld van veel burgers.

\section{Ontwikkelingen milieufactoren}

Klimaatverandering en waterbeheer worden grote uitdagingen op droogtegevoelige zandgronden in Noord-Brabant. Percelen met onvoldoende waterbeschikbaarheid worden ongeschikt voor (dure) teelten, terwijl percelen met een goede waterbeschikbaarheid juist extra interessant worden voor land- en tuinbouw. Momenteel zijn economische principes bepalend voor de ruimtelijke ontwikkeling, maar het is de verwachting dat waterbeschikbaarheid steeds meer de grondgebruiksfunctie gaat bepalen. 
Klimaatverandering zorgt voor een grote opgave in de landbouw om de uitstoot van broeikasgassen te verminderen. Het is de verwachting dat de omvang van de veestapel gaat afnemen, als gevolg van de huidige maatregelen (Sanering varkenshouderij, extern salderen met stikstof, opkoop regeling piekbelasters stikstof en mogelijk nog andere regelingen of maatregelen). Deze afname zal ook bijdragen aan de realisatie van de klimaat- en emissiedoelen.

De biodiversiteit is in recente jaren sterk achteruitgegaan. De verwachting is dat klimaatverandering eveneens druk legt op de biodiversiteit. De stikstofdepositie, vanuit het buitenland, vanuit industrie en verkeer, maar ook vanuit landbouw (m.n. veehouderij) leidt tot het verlies van natuurkwaliteit. Om de stikstofnormen in N2000 gebieden te behalen, is een forse reductie van de ammoniakemissie uit de landbouw noodzakelijk. Dat kan grote gevolgen hebben voor de landbouw, en met name de veehouderij in Brabant.

De bodemkwaliteit blijft een punt van aandacht, ook omdat er naast de productiefunctie ook steeds meer andere diensten van landbouwgrond worden verwacht, zoals waterberging en koolstofvastlegging. Een integrale benadering daarbij ten aanzien van meerdere functies is belangrijk, evenals lokaal maatwerk, bijvoorbeeld via een gebiedsgerichte aanpak.

\section{Kringlooplandbouw in Brabant}

De provincie Noord-Brabant streeft, in lijn met de landelijke visie 'Kringlooplandbouw', ook in Brabant naar een landbouw- en voedselsysteem waarvan de kringlopen gesloten zijn. Paragraaf 6.1 geeft een aantal reflecties op dit streven, waarbij gebruik gemaakt is van De Boer \& Van Ittersum (2018), Leenstra et al (2017) en De Wolf et al (2020). Vanuit deze studies komt een aantal principes naar voren:

a. Het primaire doel van een circulair systeem is het terugdringen van het gebruik van eindige hulpbronnen, zoals fossiele energie en fosfaat. Daarnaast draagt een circulair landbouwvoedselsysteem bij aan het waarborgen van natuurlijke hulpbronnen, zoals bodem, lucht, water, biodiversiteit en natuur.

b. Plantaardig voedsel boven dierlijk voedsel, zowel in productie als consumptie (De Boer \& van Ittersum, 2018)

c. Bijproducten uit de voedselketen moeten weer ingezet worden in het voedselsysteem (De Boer \& van Ittersum, 2018). Verspilling wordt tegengegaan.

d. Gebruik dieren voor dat waar ze goed in zijn (De Boer \& van Ittersum, 2018)

e. Kringlopen bestaan op meerdere schaalniveaus, van bedrijfsniveau tot mondiaal niveau, die allemaal met elkaar verbonden zijn (Leenstra et al, 2017)

f. In de landbouw-voedselkringloop zijn niet alleen bodem, gewassen, dieren en mest, maar ook industrie en consument opgenomen (de Wolf et al, 2020)

Als deze principes worden toegepast op de Brabantse context, blijkt dat het agrofood systeem vooral op economische en niet vanuit circulaire principes is ontwikkeld. Een transitie naar een circulair agrofood systeem is nauwelijks te sturen op provinciaal niveau, omdat het systeem op een veel grotere ruimtelijke schaal is georganiseerd. Een transitie van dit systeem naar een circulair agrofood systeem zou daarnaast enorme consequenties hebben, onder andere economisch en ruimtelijk.

\section{Een blik vooruit: toekomstige voedingspatroon en regionale voedselvoorziening?}

In 2019 maakte een groep internationale wetenschappers het planetary health diet: een referentie voedingspatroon van een gezond én duurzaam menu. Duurzaam betekent hier binnen de grenzen van het mondiale ecosysteem. Dit menu bestaat voor de helft uit groenten en fruit, de andere helft bestaat voornamelijk uit volkorengranen, plantaardige eiwitten, onverzadigde plantaardige olie, en een bescheiden hoeveelheid melkproducten en vlees (EAT Lancet, 2019). Meer plantaardige voeding is ook het advies van de Nederlandse Gezondheidsraad en diverse andere studies naar duurzame voedingspatronen. De 'eiwittransitie' en coalities als Green Protein Alliance spelen daarop in, evenals het landelijke Preventie Akkoord met daarin o.a. afspraken over gezonde voeding. Inspelen op zo'n toekomstig voedingspatroon, in combinatie met het fors reduceren van voedselverspilling, vergt echter naast een landbouwbeleid ook een voedselbeleid.

Om inzicht te krijgen in de mogelijkheden voor zelfvoorziening en circulariteit en de beschikbaarheid van voedsel is in hoofdstuk 6 een globale berekening gemaakt over productie en de in- en uitvoer van 
producten en grondstoffen. Het bepalen van de mogelijkheden voor zelfvoorziening op de schaal van Brabant of Noordwest Europa is niet eenvoudig. In de eerste plaats dienen productie en consumptie in evenwicht te zijn, waarbij export en import over de gebiedsgrenzen wordt uitgesloten. Dat levert voor een heel aantal producten al een probleem op, omdat de bevolking zowel in Brabant als in NWE ook producten consumeert die niet in deze regio's worden geproduceerd (zoals koffie, harde tarwe, tropisch fruit, rijst). Het uitsluiten van die producten leidt tot een drastische aanpassing van het consumptiepatroon. Voor de overige producten zou NWE redelijkerwijs zelfvoorzienend kunnen zijn, zeker als de consumptie en productie zou verschuiven van dierlijk naar plantaardig eiwit. In theorie is het mogelijk om ongeveer $80 \%$ van de voedselproductie in Noordwest Europa te realiseren. Daarin zit dan ook een verschuiving van diervoeders die meer bestaan uit reststromen uit de voedingsmiddelensector.

In Brabant is te weinig grond beschikbaar om aan de vraag te kunnen voldoen, omdat Brabant heel dicht bevolkt is. Een ander, niet onbelangrijk aspect aan zelfvoorziening is de sociaaleconomische kant: rekensommen laten theoretisch zien wat mogelijk is, maar daadwerkelijke realisatie vraagt een (stevig) ingrijpen in de markt (import, export), in de vrijheid van ondernemers en de keuzevrijheid van consumenten. Daarnaast is de governance een lastig vraagstuk: een provinciebestuur heeft nauwelijks of geen invloed, al zeker niet op het voedingspatroon van haar inwoners, en NWE is geen bestuurlijke eenheid.

\section{Aandachtspunten voor een visie}

De informatie in de vorige hoofdstukken laat een aantal dingen zien: Brabant is een belangrijke provincie voor agrofood in Nederland en in Noordwest Europa en omvat zowel toeleveranciers (bijv. machinebouw), agrarische productie als verwerking, handel en -uiteraard- consumptie. Het landbouwvoedselsysteem is echter veel groter dan de provincie Noord-Brabant, vanwege de grote internationale verwevenheid en export oriëntatie. De huidige voedselproductie en -consumptiepatronen zijn sterk gerelateerd aan een aantal urgente duurzaamheidsopgaven op het gebied van gezondheid en welzijn van mens, dier en planeet en leiden tot grote maatschappelijke kosten. De ontwikkeling van het landbouw-voedselsysteem botst in toenemende mate met de groeiende verstedelijking in Noordwest Europa en vooral ook met een aantal ecologische en gezondheidsgrenzen. Deze botsing vindt ook plaats in de provincie Brabant en vraagt ook op provinciaal niveau om visie en effectief beleid.

Het eerste aandachtspunt voor deze visie is dat er keuzes gemaakt moeten worden. Niet alles kan (overal): de fysieke ruimte is beperkt, en dat geldt ook voor milieuruimte (denk aan de stikstofemissies). Door klimaatverandering zal ook in toenemende mate competitie om (zoet) water plaatsvinden. Als verstedelijking, economische ontwikkeling, infrastructuur, energieproductie op land en de ontwikkeling van natuur (zowel de realisatie van het Ondernemende Natuurnetwerk Brabant als uitbreiding van natuur t.b.v. klimaatdoelstellingen) zich voortzetten, zal dit een fors beslag leggen op landbouwgrond. De landbouw zal zich in deze context verder intensiveren in de competitie om schaarse (steeds duurdere) grond en arbeid, in lijn met de ontwikkeling van de afgelopen decennia. En dat terwijl productiviteit van grondgebonden landbouw door klimaatverandering, zeker op de droogtegevoelige zandgronden in Brabant, onder druk staat.

Dit vraagt dus keuzes, ook op provinciaal niveau. De belangrijkste keus is het type beleid: kiest de provincie (en ook andere overheden) voor de traditionele lijn, waarin vooral randvoorwaarden worden gesteld aan economische activiteiten om schadelijke neveneffecten tegen te gaan? Dat betekent vaak dat enerzijds de landbouw aanvullende duurzaamheidseisen krijgt opgelegd, maar tegelijk in toenemende mate geconfronteerd wordt met hogere grondprijzen. Deze aanpak richt zich vaak op enkelvoudige problemen: waterkwaliteit, stikstof, energie, en is daardoor vaak reactief.

Het alternatief is een proactief, systeemgericht transitiebeleid, waarbij de uitdagingen van de toekomst meer integraal worden aangepakt. Daarbij worden maatschappelijke opgaven, in lijn met 'opgavegericht innovatiebeleid' (zie hst 4) in samenhang bekeken vanuit een lange termijn perspectief en worden niet alleen de negatieve uitkomsten aangepakt, maar juist de onderliggende oorzaken. Zo'n transitiegericht beleid vraagt dus ook om keuzes voor de toekomst: transities leiden onmiskenbaar tot botsende belangen waarbij economie soms moet worden afgewogen tegen ecologie of sociale waarden als gezondheid. Zie ook de X-curve in paragraaf 4.3 met opschalen én uitfaseren. Dat betekent dus 
ook dat gevestigde belangen niet persé leidend zijn bij beleidsontwikkeling. Dat is politiek-bestuurlijk geen eenvoudige opgave. Daartegenover staat dat de synergie tussen thema's kan worden benut; bijvoorbeeld stevig inzetten op het uitbreiden van natuur, natuur-inclusieve landbouw en vergroening in steden draagt positief bij aan biodiversiteit, klimaatdoelstellingen, reductie van emissies als stikstof, (in sommige gevallen) het watervasthoudend vermogen van de bodem, en een gezonde leefomgeving. Hetzelfde geldt voor de strategische keuze voor het versterken van de circulariteit van het landbouwvoedselsysteem; ook daar zouden synergiën met maatschappelijke opgaven kunnen worden benut maar is ook duidelijk sprake van trade-offs.

Een belangrijk aandachtspunt is dat het provinciebestuur beperkt invloed heeft op het landbouwvoedselsysteem. Dat betekent dus dat de provincie zich dus met name moet richten op de zaken waar ze wel invloed op heeft, zoals ruimtelijk beleid, milieubeleid en regionaal innovatiebeleid. Verder is het vooral van belang om samenwerking te zoeken, bijv. op landbouwbeleid met het ministerie van LNV en de EU. De provincie zou bijvoorbeeld mee vorm kunnen geven en ruimte kunnen bieden aan (beleids)experimenten van hogere overheden om (onderdelen van) het landbouwvoedselsysteem te vernieuwen of te experimenteren met het vergoeden van ecosysteemdiensten aan boeren.

Tegelijk is het belangrijk dat de provincie zich bewust is van allerlei afwentelingseffecten, naar beleidsterreinen waar ze niet over gaat en ook naar andere regio's. Zo kan de provincie actief sturen op de provinciale voedselproductie via ruimtelijk beleid en milieubeleid, maar niet of nauwelijks op de voedselconsumptie van Brabanders en al helemaal niet op buitenlandse consumenten van exportproducten vanuit Brabant. Als de vleesconsumptie gelijk blijft, zou het verkleinen van de Brabantse veehouderij mogelijk bij kunnen dragen aan de oplossing van een aantal Brabantse knelpunten, maar tegelijk leiden tot een verplaatsing van deze productie naar andere regio's/landen. Een voedse/beleid, dat nu in de EU Farm to Fork strategie wordt voorgesteld, naast een landbouwbeleid, is meer een vraagstuk van EU en de landelijke politiek, zie bijv het Preventie Akkoord. De provincie kan wel verkennen op welke wijze ze zou willen bijdragen aan 1) het versterken van de verbinding boer-burger en de waardering voor voedsel (producenten), bijvoorbeeld via korte ketens en 2) het stimuleren van voedselvaardigheden, bijvoorbeeld via onderwijs.

Een gebiedsgerichte aanpak sluit aan op de bevoegdheden en rol van de provincie: veel beleidsterreinen hebben een sterk ruimtelijke, plaatsgebonden component en komen dus fysiek samen in de regio. Het is belangrijk dat de provincie dan wel goed nadenkt over de schaal van de regio: bestuurskundige grenzen (gemeentes, waterschappen, provincie) komen niet altijd overeen met bijv. de grenzen van een landbouwgebied of een stroomgebied, en zoals gezegd is het voedselsysteem veel groter dan de provincie. Wellicht zijn sommige knelpunten op gemeentelijk of waterschapsniveau aan te pakken, maar zal voor andere uitdagingen juist provinciaal of provincie-overstijgend beleid gewerkt moeten worden. Deze verschillende schaalniveaus en bestuurlijke grenzen maken de beleidsontwikkeling niet eenvoudiger. Ook het vraagstuk van governance speelt daarbij een cruciale rol. De provincie zou daar wel een regierol kunnen vervullen en de integraliteit bewaken.

Alles overwegend is het een uitdagende tijd waarin grote transitieopgaven zorgen voor grote dynamiek in onze agrofood sector. Dit vraagt meer dan ooit om leiderschap voor het minimaliseren van trade-offs en het maximaliseren van synergiën tussen de verschillende sectoren en disciplines. De landbouw en voedselsector is als geen andere in staat om de verschillende maatschappelijke functies te combineren; vanuit de sterke positie van Brabant biedt dit veel kansen. Daarnaast is en blijft voedsel voor iedereen letterlijk van levensbelang. 


\section{$1 \quad$ Inleiding}

\subsection{Aanleiding: behoefte aan een gedragen toekomstplan voor landbouw en voedsel in Noord-Brabant}

Dit project is in maart 2020 gestart onder het bestuursakkoord 'Kiezen voor Kwaliteit' van de Provincie Noord-Brabant (PNB). Daarin werd de gewenste ontwikkelrichting van landbouw en voedsel in NoordBrabant geschetst: het produceren van het voedsel van en voor de toekomst, nieuwe teelten, hoogwaardige plantaardige eiwitten, en diervriendelijk geproduceerd voedsel dat positief bijdraagt aan de gezondheid. Gestreefd werd naar gesloten kringlopen en het minimaliseren van ongewenste effecten van de landbouw op de omgeving. In mei 2020 is er een nieuw college van GS geïnstalleerd met een nieuw bestuursakkoord: 'Samen, Slagvaardig, Slim'. Over landbouw en Voedsel wordt gesteld: In de toekomst willen we in deze sector een meer evenwichtige balans realiseren tussen de economische, maatschappelijke en ecologische waarden. Daarbij staat in beginsel ondernemerschap voorop. We zien het wel als onze verantwoordelijkheid om te sturen op randvoorwaarden: lagere emissies, een beperkte CO2-voetafdruk en een diervriendelijke aanpak verlagen de druk op onze leefomgeving. In lijn met de landelijke visie 'Kringlooplandbouw' streven wij ook in Brabant naar een landbouw- en voedselsysteem waarvan de kringlopen gesloten zijn.

\subsection{Doel: onderbouwde input voor visievorming}

In het kader van de ontwikkeling van een visie op landbouw en voedsel was er bij de Provincie NoordBrabant de behoefte om de huidige situatie in beeld te brengen en een inschatting te maken van (maatschappelijke) ontwikkelingen tot 2040. Het agrofood systeem is complex, er zijn enorm veel partijen bij betrokken waaronder leveranciers van grondstoffen, gebouwen, machines en diensten, verwerkende industrieën, handel, retail en financiële dienstverleners. Een visie op landbouw en voedsel raakt daarom niet alleen de boer maar alle betrokken partijen in het voedselsysteem, waaronder niet in de laatste plaats de burger. Daarnaast is het agrofood systeem zelf ook weer gerelateerd aan andere domeinen als energie en water. Bovendien is ons agrofood systeem sterk internationaal georganiseerd. Door de vele spelers en de internationale structuur is er sprake van een enorme dynamiek die lastig is te overzien. Daar komt nog bij dat ten aanzien van landbouw en voedsel veel visies en opvattingen rondgaan in het publieke domein en dat er veel perspectieven zijn over de gewenste ontwikkelrichting.

Het is niet eenvoudig om in die context een samenhangende visie te maken. Dit rapport heeft als doel om te schetsen welke ontwikkelingen een rol spelen en welke aandachtspunten daaruit voortvloeien die bij visievorming over ontwikkelrichtingen van de agrofood sector in Noord Brabant relevant zijn. Het rapport trekt geen conclusies, maar formuleert vanuit de analyse een aantal aandachtspunten voor de opdrachtgever bij de visieontwikkeling. 


\section{Afbakening, werkwijze en methodische verantwoording}

\subsection{Het verloop van het project}

Het project kent een bijzonder verloop waarbij op enkele momenten op verzoek van de Provincie Noord Brabant wijzigingen zijn aangebracht in de werkwijze en focus van de studie.

Er zijn diverse methodes om toekomstverkenningen te maken. Vaak wordt dit gedaan aan de hand van scenario's, op nationale en internationale schaalniveaus. Meestal gaat het dan om thematisch afgebakende verkenningen, bijvoorbeeld over klimaat of landbouw. In dit project gaat het om een integrale toekomstverkenning van landbouw, voedsel en leefomgeving. Deze verkenning is op verzoek van de provincie niet via scenario's uitgewerkt maar in een beschrijving van het huidige agrofood systeem en te verwachten ontwikkelingen.

Het project is in drie stappen ingedeeld:

- $\quad$ Stap 1: Het beschrijven van de huidige situatie op drie ruimtelijke niveaus, nl. Noordwest Europa (NWE), Nederland (NL) en Noord-Brabant (NB) in 2020 en van trends en ontwikkelingen naar 2040. (Hoofdstukken 3, 4 en 5):

- De beschrijving van het agrofood systeem is gestructureerd volgens de Voedsel-SysteemAnalyse (VSA) zoals beschreven door Van Berkum et al. (zie hoofdstuk 3).

- Als eerste is een analyse van het huidige agrofood systeem gemaakt om beter in beeld te kunnen krijgen waar sterkten liggen en waar opgaves liggen.

- Als tweede zijn ontwikkelingen geschetst (zie hoofdstuk 5), waarbij zowel 'zekere' en 'onzekere' ontwikkelingen zijn meegenomen. De zekere ontwikkeling zijn bijvoorbeeld klimaatverandering en ontwikkelingen in demografie zoals vergrijzing. Daarvan is de algemene verwachting dat deze zullen doorzetten. Onzekere ontwikkelingen zijn die ontwikkelingen waarvan op dit moment onduidelijk is welk effect ze zullen hebben, bijvoorbeeld de effecten van de Covid-19 pandemie.

- $\quad$ Stap 2: Het bespreken van deze gegevens met een afvaardiging van de Provincie Noord-Brabant. Dit vond plaats op 10 sept 2020. Deze discussie heeft geresulteerd in een aantal aandachtspunten die in de tekst zijn verwerkt. Een toekomstbeeld van de agrofood sector is op verzoek van de provincie weggelaten.

- Stap 3: Het reflecteren op de gegevens via het benoemen van afwegingen (hoofdstuk 7). Daarin is door het projectteam een interpretatie geschreven van de verzamelde informatie als aandachtspunten voor het beleid. Deze interpretatie is bedoeld als aanzet voor de verdere discussie binnen de provincie.

\subsection{Inhoudelijke werkwijze}

Om iets zinvols te zeggen over de toekomst, is een goede analyse van het heden onmisbaar. Daarom is gekozen voor een voedselsysteembeschrijving (2.2.1) op verschillende ruimtelijke niveaus (2.2.2), gevolgd door een toekomstverkenning 2.2.3).

\subsubsection{Voedselsysteembeschrijving}

De combinatie landbouw en leefomgeving is geen onbekende, zeker niet in de provincie NoordBrabant, waar het intensieve grondgebruik van plantaardige productie en de intensieve veehouderij 
een grote invloed hebben op de leefomgeving. Daarnaast wordt uiteindelijk (bijna ${ }^{1}$ ) alles wat we produceren opgegeten, ergens in de wereld. Verder is er toenemende aandacht voor de relatie tussen productie en consumptie op lagere ruimtelijke schaalniveaus, bijvoorbeeld vanuit de kringloopgedachte of vanuit lokale of regionale ketens. Productie en consumptie van voedsel worden sterk bepaald door economische, sociale en culturele factoren. Dat wordt omschreven als het agrofood systeem. Om het agrofood systeem in kaart te brengen wordt gewerkt met de voedselsysteem beschrijving. Dit is een systematische benadering waarin alle aspecten van het agrofood systeem aan bod komen. De systeembenadering wordt veel toegepast in wetenschappelijke analyses, met name bij complexe systemen met veel onderlinge relaties.

Er zijn veel voedselsysteem benaderingen, ook internationaal. Hier is gekozen voor het Food System Framework ontwikkeld door Wageningen UR (Van Berkum et al., 2018). Zie figuur 2.1.

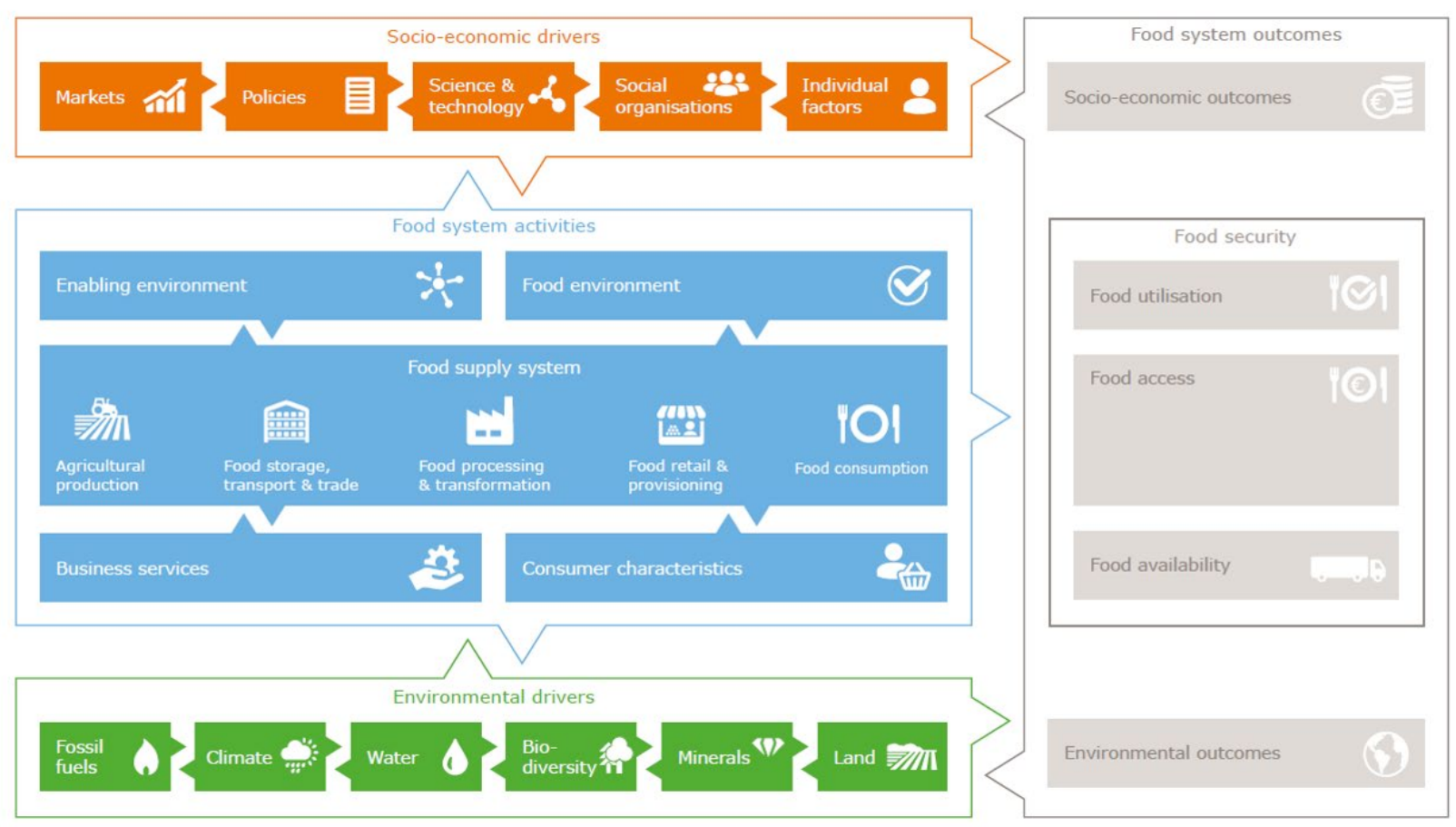

Figuur 1.1 Een voedselsysteem framework zoals beschreven door Van Berkum et al. (2018).

De voedselsysteem benadering kenmerkt zich door niet alleen het landbouwsysteem te bekijken, maar deze te verbinden met het voedselsysteem en ook de sturende factoren vanuit sociaaleconomische context en milieu aspecten in beschouwing te nemen. Deze 'drivers' beïnvloeden én worden zelf ook beïnvloed door de activiteiten van het agrofood systeem. Tenslotte beschrijft de aanpak ook de uitkomsten van het voedselsysteem op sociaaleconomische aspecten als werkgelegenheid en economie, voedselzekerheid en (humane) gezondheid, en op milieu aspecten. Achterliggende insteek is dat als je bepaalde (negatieve) uitkomsten van het voedselsysteem wil veranderen, je op meerdere plekken in het systeem interventies nodig hebt. Een integrale benadering.

\subsubsection{Kijken naar drie ruimtelijke niveaus}

Noord-Brabant staat niet op zichzelf, het agrofood systeem heeft sterke relaties met de omliggende gebieden. Omdat in de vraagstelling de focus op Noordwest Europa is gelegd, worden ontwikkelingen onderzocht op drie niveaus: Noord-Brabant, Nederland en Noordwest Europa (NB, NL en NWE) In deze studie is NWE gedefinieerd als België, Frankrijk, Duitsland, Luxemburg, Ierland en Nederland. Deze landen zijn de belangrijkste landen voor de import en export van voedselproducten. Deze landen behoren ook tot dezelfde klimaatzone. Het Verenigd Koninkrijk is buiten beschouwing gelaten, omdat deze geen EU lid meer is en de gevolgen voor handel niet zijn in te schatten.

\footnotetext{
${ }^{1}$ Dit geldt niet voor de sierteeltproducten, zoals bloembollen, bomen en vaste planten, die ook in Brabant worden geproduceerd.
} 


\subsubsection{Toekomstverkenning}

Er zijn meerdere methodes om toekomstverkenningen te doen. Op hoofdlijnen kan het gaan om:

- forecasting: het extrapoleren van huidige trends in de tijd, deze trends kunnen variëren in de mate van zekerheid

- $\quad$ scenario's ontwikkelen, bijvoorbeeld met een 2x2 matrix waarin op het assenkruis de meest onzekere trends zijn geplot

- backcasting: uitgaande van de 'ideale' of gewenste toekomst terug redeneren naar het nu om aan te kunnen geven welke stappen nu gezet kunnen worden om naar de gewenste situatie te komen.

In eerste instantie zouden backcasting en forecasting beide worden gebruikt. In een later stadium is dit beperkt tot de forecasting, aangezien de Provincie in deze studie geen eindbeeld voor 2040 wilde vaststellen. De beschrijving wordt geen toekomstvoorspelling, want dat is ten enenmale onmogelijk. Het is een kwalitatieve beschrijving van ontwikkelingen die meer of minder zeker zijn, van dilemma's die zullen optreden en van de betekenis voor de provincie Brabant. Voor een deel zijn het bekende dilemma's, voor een deel zullen het nieuwe beschouwingen zijn die inzicht geven in keuzes die gemaakt moeten worden of problemen die zich in de toekomst kunnen voordoen. 


\section{De huidige situatie Noord-Brabant}

\subsection{Voedselsysteem activiteiten}

Voedselsysteem activiteiten betreffen alle processen die te maken hebben met de productie en benutting van voedsel. Alle activiteiten hebben hun inputs en leiden tot producten, genereren inkomens en beschikbaarheid van voedsel, samen met effecten op de leefomgeving. Het voedselsysteem wordt bepaald door economische, sociale, culturele, politieke, technologische en biofysische factoren (Van Berkum et al., 2018). In de context van dit project ligt de focus op de landbouwproductie in verbinding met voedselconsumptie en leefomgeving, omdat deze een centrale rol vervult in het gehele systeem en van sterke invloed is op de omgeving.

\subsubsection{De primaire productie}

De landbouwproductie is het centrale punt in het voedselsysteem en de gehele waardeketen eromheen. Het heeft traditioneel een belangrijke rol vervuld. Nog steeds werkt meer dan $50 \%$ van de mensen in Afrika, Azië en Latijns-Amerika in de primaire landbouw. In geïndustrialiseerde landen is dat veel lager en ligt het rond de $2-5 \%$. Het voedselsysteem is ingebed in een ondersteunende infrastructuur van overheden, organisaties en instellingen die samen de omstandigheden bepalen waaronder wordt geproduceerd (Van Berkum et al., 2018).

Het voedselproductiesysteem in NWE is te omschrijven als grotendeels intensief. Een groot deel van het land is in gebruik als gras- en bouwland. Volgens de FAOstat database, zijn tarwe, aardappelen, suikerbieten en gerst de belangrijkste gewassen met de hoogste financiële bijdrage. In Nederland is de agrifood sector goed voor ongeveer $10 \%$ van het nationaal inkomen en werkt ongeveer $10 \%$ van alle arbeid in de landbouw en de aanpalende bedrijven, leveranciers en afnemers/verwerkers. De Nederlandse landbouw is ook goed voor $25 \%$ van de nationale exportwaarde en $50 \%$ van het handelsoverschot. Nederland is de tweede exporteur van landbouwproducten ter wereld. Jaarlijks genereert de gehele sector 50 miljard euro aan toegevoegde waarde en is het goed voor 80 miljard euro aan export. (ec.europa.eu).

Binnen NWE speelt Nederland een belangrijke rol bij verse groenten en tuinbouwproducten (ook nonfood). Nederland is de belangrijkste producent van onder meer tomaten, uien, peren, paprika, aardbeien, komkommers, en champignons (FAOstat database). Een andere belangrijke groep producten zijn de sierbloemen en -planten, waar Nederland veruit de grootste mondiale producent is met een totale waarde van 13.5 miljard euro (Figuur 3.1). 


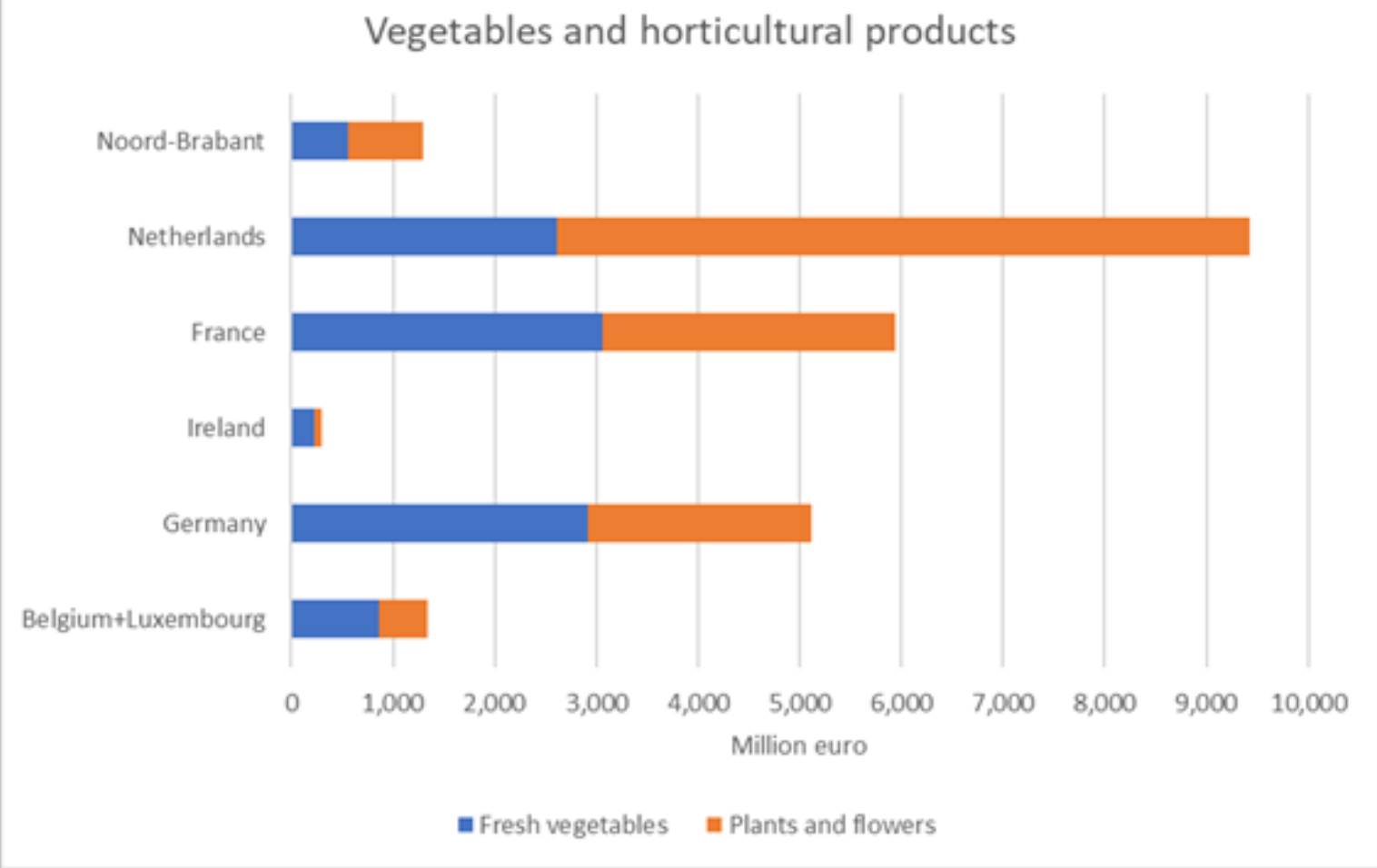

Figuur 2.1 Productiewaarde van groenten en tuinbouwproducten in 2016 in landen in NWE en in NB (Bron: EUROstat database).

Noord-Brabant speelt een belangrijke rol in de Nederlandse land- en tuinbouw, met een aandeel van $18 \%$ van het aantal bedrijven en $17 \%$ van de totale toegevoegde waarde. Van de 500000 hectare grond die de provincie groot is, is 232000 hectare in gebruik als landbouwgrond, ongeveer $13 \%$ van de totale oppervlakte in Nederland. Sterke sectoren in Noord-Brabant zijn de gespecialieerde melkveehouderij, maar vooral de varkenshouderij. Eén op de acht landbouwbedrijven in Brabant is een varkensbedrijf (Venema et al., 2019). Daarmee is in de dierhouderij de varkenshouderij een belangrijke pijler van de Brabantse plattelandseconomie. (Brabant.nl, Figuur 3.2).

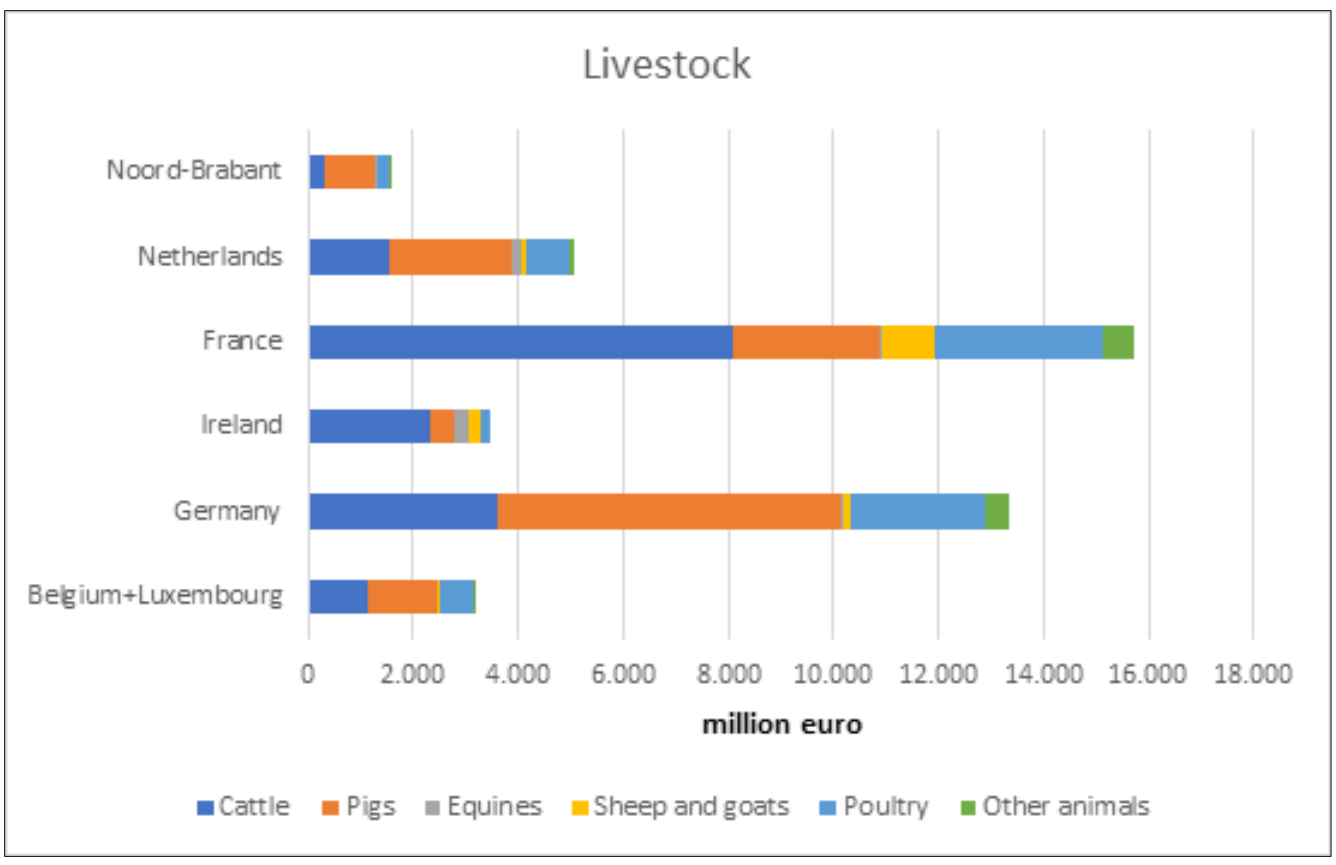

Figuur 3.2 Toegevoegde waarde productie van de veehouderij in NWE en NB (Bron: EUROstat database). 
Als het bruto product per hoofd van de bevolking wordt vergeleken in NWE en NB (Figuur 3.3), dan is te zien dat varkens en groente veruit de hoogste zijn in NB en dat melk in NB (en NL) alleen worden voorbij gestreefd door Ierland, waar melkveehouderij de belangrijkste sector is. Het bruto product van varkens in NB is vergelijkbaar met dat van melk in Ierland. Granen en industriegewassen spelen slechts een beperkte rol in NB en NL, zeker in vergelijking met grote producenten als Duitsland en Frankrijk.

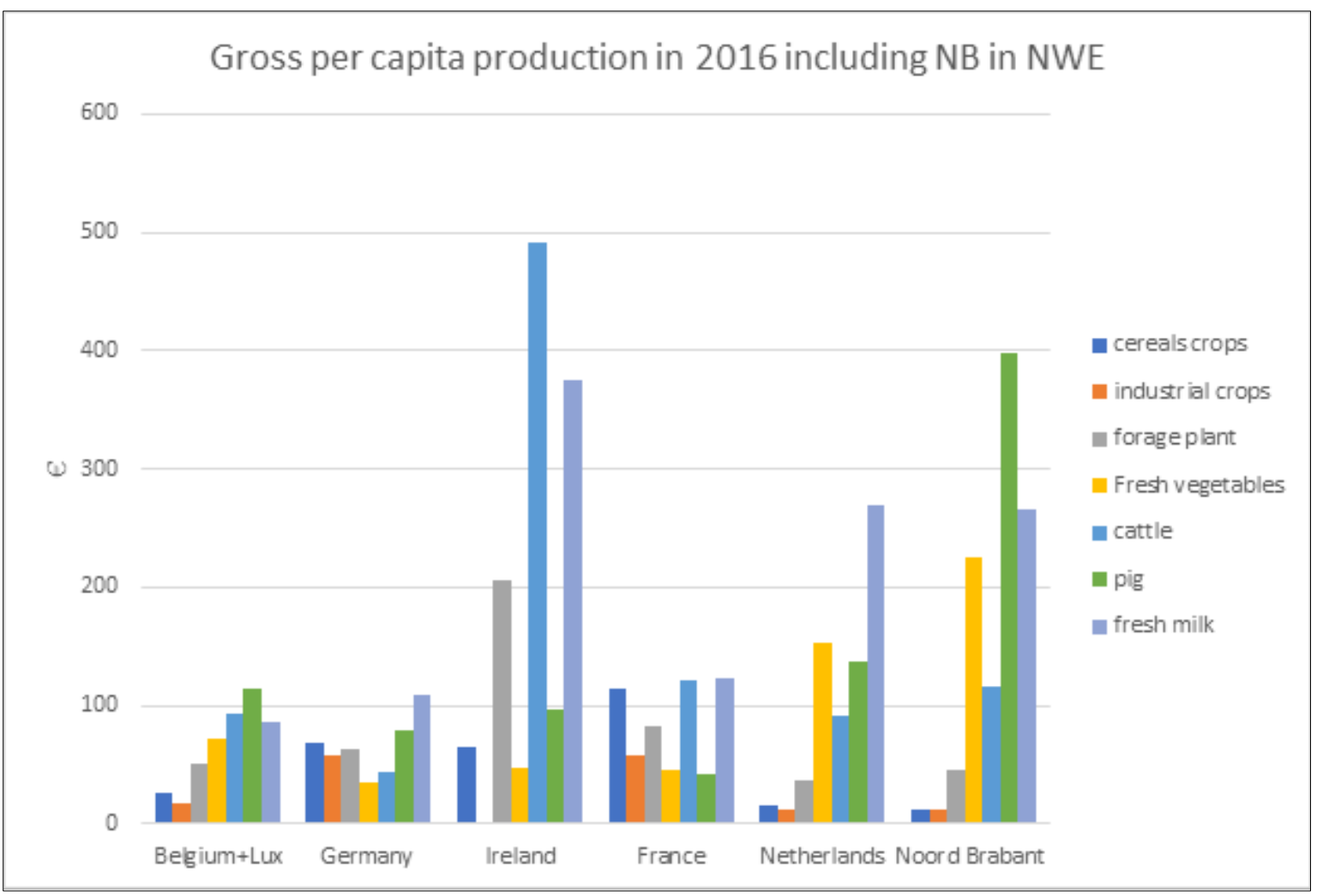

Figuur 3.3 Het bruto product per hoofd van de bevolking van de verschillende landbouwsectoren in NWE en NB (Bron: FAOstat, Eurostat database).

Bij een nadere blik op Noord-Brabant, is te zien dat de bijdrage van de land- en tuinbouw (primaire bedrijven, toeleverende bedrijven en verwerkende industrie samen) aan de netto toegevoegde waarde en werkgelegenheid aanzienlijk is. De sector zorgt voor 6.3 Miljard euro aan netto toegevoegde waarde en 76400 mensjaren aan arbeid. Dat is respectievelijk 6.5 en $7.1 \%$ van de Brabantse economie en werkgelegenheid en respectievelijk $18.8 \%$ en $17.6 \%$ van de Nederlandse landbouw sector (Venema et al., 2019). ${ }^{2}$

Andere belangrijke sectoren in de provincie zijn de sierplanten en -bloemen en de boomteelt. Deze laatste tak is sterk vertegenwoordigd in Noord-Brabant en neemt binnen Nederland een steeds belangrijker positie in (Brabant.nl). De boomteelt is vooral geconcentreerd rond Zundert, de regio rond Haaren en het land van Cuijk. De marktwaarde van deze drie takken bedraagt jaarlijks ongeveer 730 miljoen euro (Eurostat). In het jaar 2016 was de netto toegevoegde waarde in Brabant hoger dan die van België, Luxemburg en Ierland samen.

Figuur 3.4 toont de verdeling van de standaard opbrengst in duizenden euro's per vierkante kilometer. Grote delen van de provincie Noord-Brabant, en met name het oosten ervan, laten een hoge standaardopbrengst zien (Venema et al., 2019).

\footnotetext{
2 Deze gegevens betreffen de prestaties van het agrocluster op basis van binnenlandse grondstoffen. Als ook de buitenlandse grondstoffen worden meegenomen, dan komen deze percentages hoger uit, namelijk op respectievelijk 12,2 en $11,1 \%$ van de toegevoegde waarde en werkgelegenheid in Brabant en 22,9 en 19,0\% van de toegevoegde waarde en werkgelegenheid van het Nederlandse agrocluster (Wageningen Economic Research, op basis van LISA, bestand van KvK)
} 


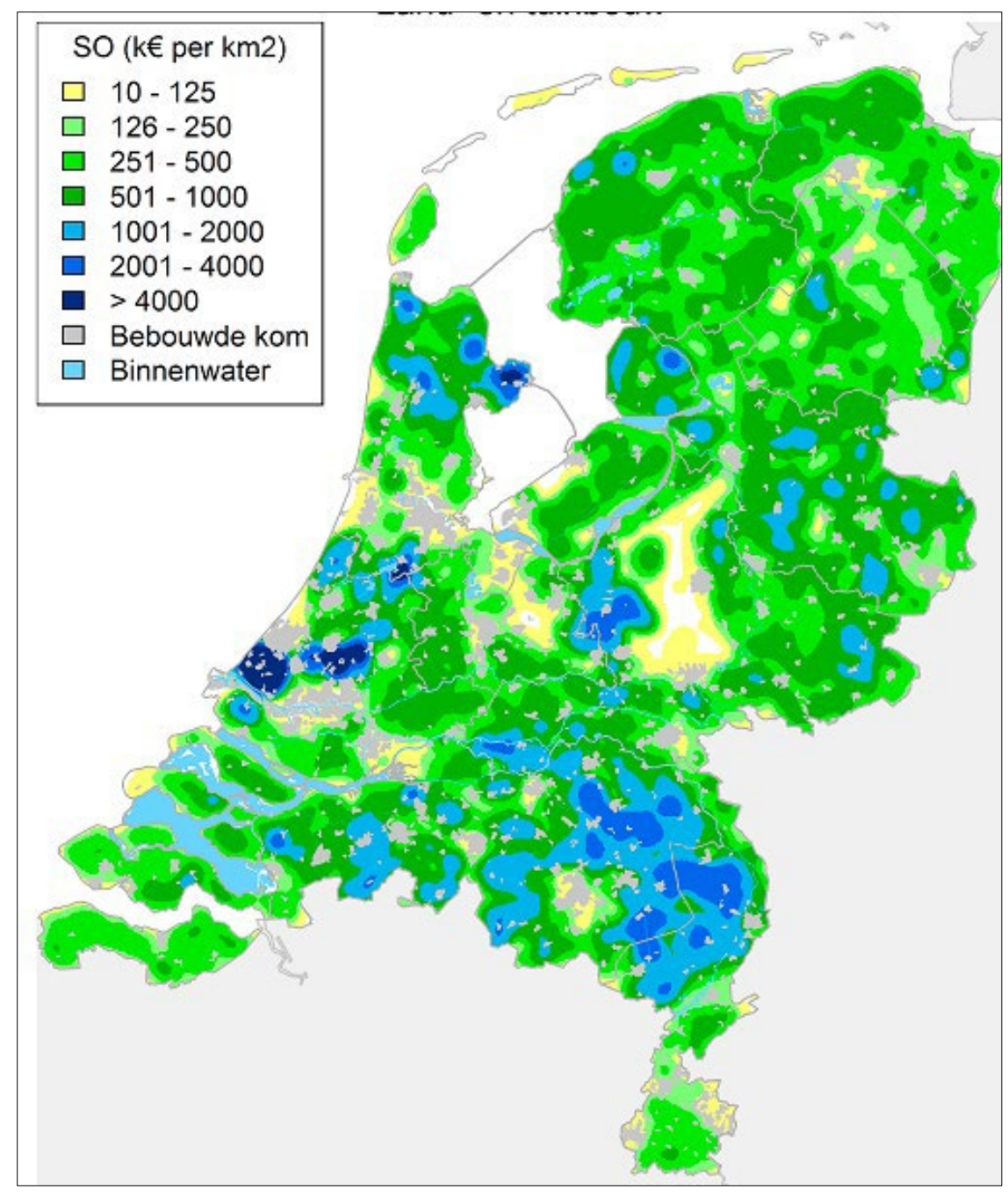

Figuur 3.4 Ruimtelijke verdeling van de Standaardopbrengst (SO) in de land- en tuinbouw in Nederland, 2017. (Venema et al., 2019).

Als naar de totale werkgelegenheid in de provincie wordt gekeken is een kwart actief in de dienstverlening (25.1\%) en groothandel (24.6\%). Daarnaast is de industrie goed voor $13.6 \%$ en 11.6 in ondersteunende diensten. De werkloosheid was in 2018 lager (3.5\%) dan het Nederland gemiddelde $(3.8 \%)$.

\subsubsection{Biologische landbouw}

De Europese Unie wil een verandering in de richting van een gezonder en meer duurzaam EU voedselsysteem. Dit wordt beschreven in de Farm to Fork (F2F) strategie, die de kern is van de Europese Green Deal. Het doel is om voedselsystemen eerlijker, gezonder en milieuvriendelijker te maken. Het is een veelomvattend programma om de Europese voedselketen te verduurzamen en de impact van voedselproductie op het milieu en het klimaat te verminderen. Volgens F2F moeten we 'ons voedselsysteem herontwerpen' omdat het verantwoordelijk is voor bijna éénderde van de mondiale broeikasgas emissies, een grote hoeveelheid natuurlijk hulpbronnen gebruikt, resulteert in verlies van biodiversiteit en negatieve gezondheidsimpacts (zowel onder- als overvoeding) en geen eerlijke economische inkomsten en leefomstandigheden creëren voor alle actoren, in het bijzonder primaire producenten (https://ec.europa.eu/food/farm2fork_en). Onderdeel van de Farm to Fork strategie is het doel om $25 \%$ van de landbouwgrond in biologische landbouw om te zetten in 2030. De F2F visie laat de richting zien waar de Europese Commissie heen wil. Tegelijk is het een ambitieus voorstel wat nog niet politiek vastgesteld is, en ook een behoorlijke hervorming vraagt van het (Europese) gemeenschappelijk landbouwbeleid. 
In Noord-Brabant is het aandeel van biologische bedrijven gestegen van 1.2 naar $1.7 \%$ en het areaal van 1.9 naar $2.1 \%$ (Figuur 3.5). Deze percentages zijn lager dan de landelijke gemiddelden. Ook de toename van de biologische landbouw in andere delen van Nederland groeit sneller dan in NoordBrabant. Het areaal biologische landbouwgrond bereikte in 20181000 hectare (Venema et al., 2019).

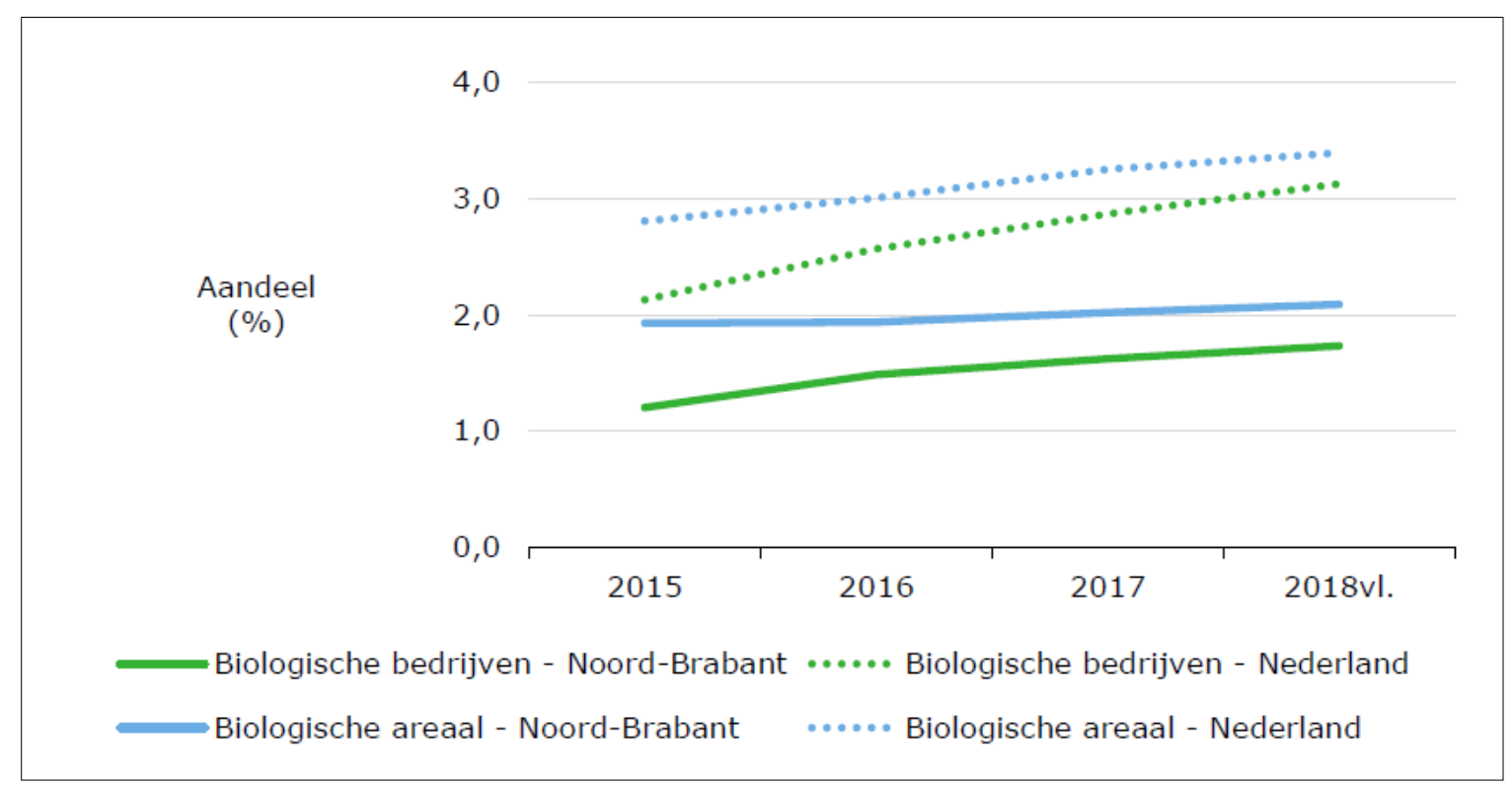

Figuur 3.5 Aandeel van biologische bedrijven en arealen in het totaal in NB en Nederland, 20152018 . Source: Venema et al. (2019).

\subsubsection{Voedselverwerking en handel}

PBL (2019) beschrijft welk deel van de nationale productie binnen Nederland wordt verwerkt en geconsumeerd (zie ook hoofdstuk 3.2.2), welk deel van buiten Nederland komt. Van beide stromen, zowel Nederlandse als buitenlandse producten wordt een aanzienlijk deel in Nederland verwerkt tot eindproducten. Een deel van die eindproducten wordt vervolgens geëxporteerd. Het betekent dat het agrofood systeem in Nederland sterk is verknoopt met de systemen in het buitenland. Deze internationalisering heeft niet alleen in Nederland plaatsgevonden, maar ook in andere landen in NWE. Deze internationalisering is ten koste gegaan van de meer traditionele en regionale distributie van grondstoffen en producten (Krijn Poppe, persoonlijke mededeling, 7 juli 2020). Grote Brabantse ondernemingen zijn in iedere schakel van het landvoedselsysteem actief. Mondiale spelers zijn FrieslandCampina, Danone, Bavaria, Mars, Hero, InBev, Rijkzwaan, Nutreco, Pigture Group, VION Food, HAK en Koninklijke Cosun. De totale lijst van belangrijke agrifood bedrijven in Noord-Brabant bevat ongeveer 250 bedrijven (Interreg, 2020). Deze bedrijven zijn sterk in het vertalen van kennis in nieuwe en verbeterde producten. Een gevolg daarvan is dat Noord-Brabant steeds meer wordt gekenmerkt door grote verwerkende bedrijven, mede dankzij de strategische positie tussen Antwerpen, Rotterdam en het Duitse Ruhrgebied.

Naast de voedselverwerkende sector, zijn in de afgelopen vijf jaar de logistieke bedrijven en groothandels verantwoordelijk voor ongeveer twee derde van de vraag naar ruimte op bedrijven terreinen. De industrie was goed voor $20 \%$ van de ruimtevraag (Stecgroep, 2018). Tabel 1 toont de ruimtelijke verdeling van een aantal van de genoemde bedrijven binnen de provincie Noord-Brabant. 


\begin{tabular}{|c|c|c|c|c|}
\hline & Midden & Noordoost & West & Zuidoost \\
\hline Aantal banen & 198.000 & 321.000 & 325.000 & 418.000 \\
\hline $\begin{array}{l}\text { Aantal banen op } \\
\text { bedrijventerreinen } \\
\text { (bindingspercentage/ } \\
\text { locatietypevoorkeur) }\end{array}$ & $\begin{array}{r}73.000 \\
(37 \%)\end{array}$ & $\begin{array}{r}115.000 \\
(36 \%)\end{array}$ & $\begin{array}{c}117.000 \\
(36 \%)\end{array}$ & $\begin{array}{c}164.000 \\
(39 \%)\end{array}$ \\
\hline $\begin{array}{l}\text { Omvang } \\
\text { bedrijventerreinen- } \\
\text { voorraad (netto } \\
\text { uitgegeven) }\end{array}$ & $\begin{array}{c}1.909 \\
\text { hectare }\end{array}$ & $\begin{array}{c}2.668 \\
\text { Hectare }\end{array}$ & $\begin{array}{c}5.057 \\
\text { hectare }\end{array}$ & $\begin{array}{c}3.240 \\
\text { hectare }\end{array}$ \\
\hline $\begin{array}{l}\text { Gemiddeld } \\
\text { ruimtegebruik op } \\
\text { bedrijventerreinen }\end{array}$ & $\begin{array}{c}259 \mathrm{~m}^{2} \\
\text { per werknemer }\end{array}$ & $\begin{array}{c}229 \mathrm{~m}^{2} \\
\text { per werknemer }\end{array}$ & $\begin{array}{c}365 \mathrm{~m}^{2} \\
\text { per werknemer }\end{array}$ & $\begin{array}{c}185 \mathrm{~m}^{2} \\
\text { per werknemer }\end{array}$ \\
\hline $\begin{array}{l}\text { Groeisectoren in } \\
\text { werkgelegenheid } \\
(2010-2017)\end{array}$ & $\begin{array}{l}\text { - Chemische industrie } \\
\text { - VGM } \\
\text { - Logistiek }\end{array}$ & $\begin{array}{l}\text { - HTSM } \\
\text { - Consumentendiensten }\end{array}$ & $\begin{array}{l}\text { - Chemische industrie } \\
\text { - Consumentendiensten }\end{array}$ & $\begin{array}{l}\text { - HTSM } \\
\text { - VGM } \\
\text { - Consumentendiensten }\end{array}$ \\
\hline $\begin{array}{l}\text { Beeldbepalende } \\
\text { bedrijven op } \\
\text { bedrijventerreinen }\end{array}$ & $\begin{array}{l}\text { - Bosch Transmission } \\
\text { - Albert Heijn DC } \\
\text { - Fujifilm } \\
\text { - Docdata } \\
\text { - I.F.F. } \\
\text { - Coca Cola } \\
\text { - Tesla } \\
\text { - Bol.com } \\
\text { - Rhenus Logistics } \\
\text { - GVT Logistics } \\
\text { - Van Haaren } \\
\text { - Spar } \\
\text { - Syncreon }\end{array}$ & $\begin{array}{l}\text { - MSD } \\
\text { - Vanderlande } \\
\text { - Mars / Masterfoods } \\
\text { - Marel Stork Poultry } \\
\text { - Bosch Rexroth } \\
\text { - Heineken } \\
\text { - Würth } \\
\text { - Sligro } \\
\text { - Jumbo } \\
\text { - Danone / Nutricia } \\
\text { - Vos Logistics } \\
\text { - Friesland Campina } \\
\text { - SCA Hygiene } \\
\text { - Heineken } \\
\text { - Vion }\end{array}$ & $\begin{array}{l}\text { - SABIC } \\
\text { - Schenker Logistics } \\
\text { - Shell } \\
\text { - Fokker } \\
\text { - Amgen Europe } \\
\text { - Meeus Group } \\
\text { - Ricoh } \\
\text { - Fokker } \\
\text { - IKEA } \\
\text { - Bleckmann } \\
\text { - Spie Nederland } \\
\text { - DSV } \\
\text { - Martens van Oord }\end{array}$ & $\begin{array}{l}\text { - ASML } \\
\text { - DAF Trucks } \\
\text { - Philips } \\
\text { - Van Rooi Meat } \\
\text { - Prodrive Technologies } \\
\text { - KMWE } \\
\text { - XPO/Menlo } \\
\text { - VDL } \\
\text { - DAF } \\
\text { - Nyrstar (Metalot) } \\
\text { - Refresco } \\
\text { - Bavaria } \\
\text { - Hectas }\end{array}$ \\
\hline
\end{tabular}

\subsubsection{Ondersteunende factoren}

Ondersteunende factoren in het AFS zorgen dat het systeem soepel functioneert. De ondersteunende factoren zijn enerzijds de harde infrastructuur met bijvoorbeeld wegen, verwerkende industrie en transport en anderzijds de zachte infrastructuur met diensten zoals dierenartsen, consultants, accountants, regelingen, belangenorganisaties en kennisinstellingen voor onderzoek en onderwijs. Ook de retail met zijn efficiëntie distributie is onderdeel van het ondersteunende systeem.

Nederland heeft door zijn ligging grote voordelen om onderdeel uit te maken van een wereldwijd AFS, Twee belangrijke havens voor overzeese handel, Rotterdam en Antwerpen hebben uitstekende verbindingen met het achterland via een uitstekend netwerk van wegen en spoorlijnen. Noord Brabant ligt erg gunstig ten opzichte van de beide voornoemde havens en de afstand tot een belangrijk afzetgebied in Duitsland is beperkt. Daarmee heeft Noord-Brabant een goede positie.

Als het gaat over dienstverlening, Noord-Brabant is een belangrijk knooppunt voor kennis en technische innovatie, via onder meer de Brainport Eindhoven en de verbindingen met een groot aantal internationaal opererende verwerkende bedrijven. Dat wordt nader uitgewerkt in paragraaf 3.2.6.

\subsubsection{Samenvatting voedselsysteemactiviteiten}

De provincie Noord-Brabant is een van de belangrijkste landbouwgebieden in Nederland. Ze is verantwoordelijk voor $17,5 \%$ van het totale Nederlandse agrofood-export en $20 \%$ van Nederlandse agrofood productie. De toegevoegde waarde per hoofd van de bevolking is hoog, zeker in aanmerking nemend dat in Brabant slechts een beperkt deel van de mensen in de landbouw en aanpalende sectoren werkzaam is. Een van de belangrijke sectoren is de varkensvleesproductie, verantwoordelijk voor ongeveer 1 miljard euro per jaar (dit is het hoogste BBP vergeleken met de Noordwest Europa regio). Andere belangrijke landbouwsectoren in Brabant zijn sierplanten \& bloemen, verse melk en verse groenten. Er is sprake van een zeer hoge standaard opbrengst van de landbouw, met name in het oosten van de provincie. 
De verschillende bedrijven die de hele voedselketen 'van grond tot mond' omvatten maken NoordBrabant tot een van de meest geconcentreerde gebieden van de wereld waar veel ketenspelers efficiënt samenwerken. Van oudsher zijn dit vaak coöperaties, die zich in de loop der jaren hebben ontwikkeld tot internationaal belangrijke spelers (Venema et al., 2019).

Daarnaast is er een concentratie van varkenshouderij in met name het oosten van de provincie. Ook de melkveehouderij is intensief ten opzichte van melkveehouderij elders in Nederland (Venema et al., 2019).

Het aandeel biologische landbouw in Noord-Brabant ligt onder het landelijk gemiddelde (in 2018 resp. 2.1 en $3.4 \%$ van het landbouwareaal; Venema et al., 2019). De strategische positie van Brabant tussen Rotterdam, Antwerpen en de Duitse stedelijke centra is een belangrijk voordeel.

Wat betreft de intensieve, niet-grondgebonden veehouderij is Brabant sterk afhankelijk van importen van (veevoer)grondstoffen van buiten Nederland, deels uit de EU en deels van buiten de EU.

\subsection{Sociaaleconomische factoren}

Sociaaleconomische factoren van het AFS hebben invloed op de productie en de consumptie. Omgekeerd beïnvloeden deze beide ook weer de sociaaleconomische factoren. Deze factoren helpen om een beter begrip te krijgen van de wijze van produceren en consumeren. Er worden vijf categorieën onderscheiden: markt, beleid, wetenschap en technologie, sociale organisaties en individuele factoren. Een aantal sociaaleconomische trends vormen de basis voor deze factoren (Van Berkum et al., 2018): demografische ontwikkelingen, verstedelijking, macro-economische groei en culturele en politieke ontwikkelingen. Eerst zullen deze trends worden beschreven om een beeld te krijgen van de huidige situatie. De verkenning naar 2040 vindt plaats in het volgende hoofdstuk.

\subsubsection{Bevolking}

Nederland heeft een aparte positie binnen NWE als het gaat om bevolking en verstedelijking. De groei van de Nederlandse bevolking zal naar verwachting beperkt zijn. De VN verwacht een ontwikkeling van 16,9 miljoen in 2020 naar 17,7 miljoen in 2040 (UN population division, 2019). Als dan wordt gekeken naar de leeftijdsopbouw van de bevolking, zie je een verdergaande vergrijzing. Dat is ook duidelijk het geval voor Noord-Brabant (Figuur 3.6). Nederland heeft de hoogste bevolkingsdichtheid van de NWE landen met 540 mensen per $\mathrm{km}^{2}$. 76.8 procent van de bevolking woont in stedelijke gebieden en de verwachting is dat dit zal stijgen tot $90 \%$ in 2040. De verstedelijking in Nederland vindt plaats in stedelijke regio's met meerdere centra en niet in enkele zeer grote steden. Het betekent dat meerdere steden dicht bij elkaar liggen, waarbij de grenzen tussen stad en platteland vaak niet scherp te trekken zijn. Op deze manier ontstaat een grote stedelijke regio, die vergelijkbaar is met de Randstad. De mate van verstedelijking in Europa is getoond in Figuur 3.7, waarbij vooral de concentratie van stedelijke gebieden en regio's opvalt. De ontwikkeling van de bevolking is niet gelijk verdeeld over Nederland (Figuur 3.8). De groei vindt vooral plaats in clusters van stedelijke en verstedelijkte gebieden, ook buiten West Nederland. Dat geldt ook voor Noord-Brabant (Figuur 3.9). Tegelijkertijd is de verwachting dat het aantal personen per huishouden zal afnemen. In 2018 was dat nog 2.20, terwijl de verwachting is dat het in 2030 afneemt naar 2,12 (Provincie Noord Brabant, 2017). 


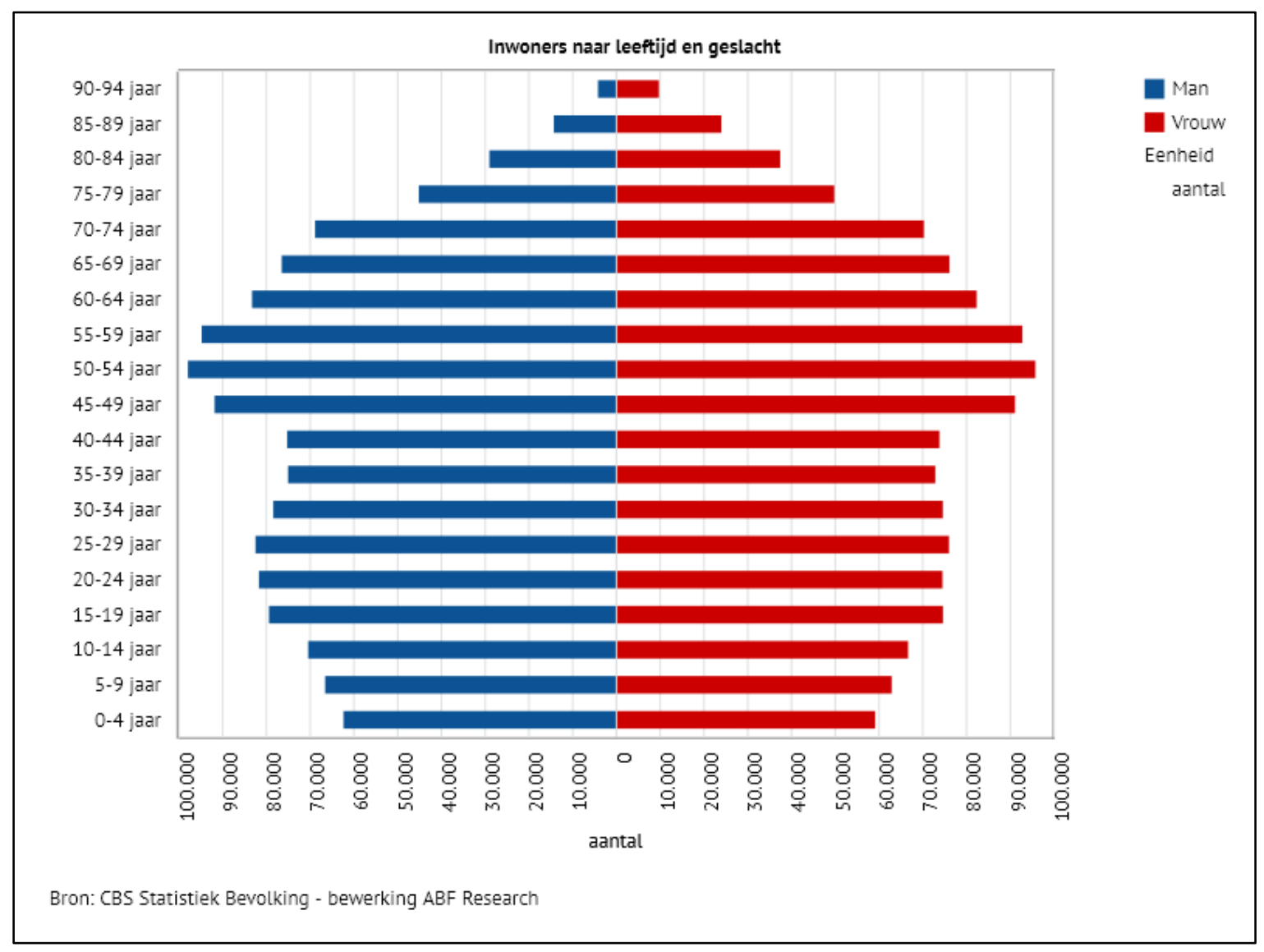

Figuur 3.6 De bevolkingsopbouw in Noord-Brabant in 2017. Bron: provincie Noord-Brabant, 2017.

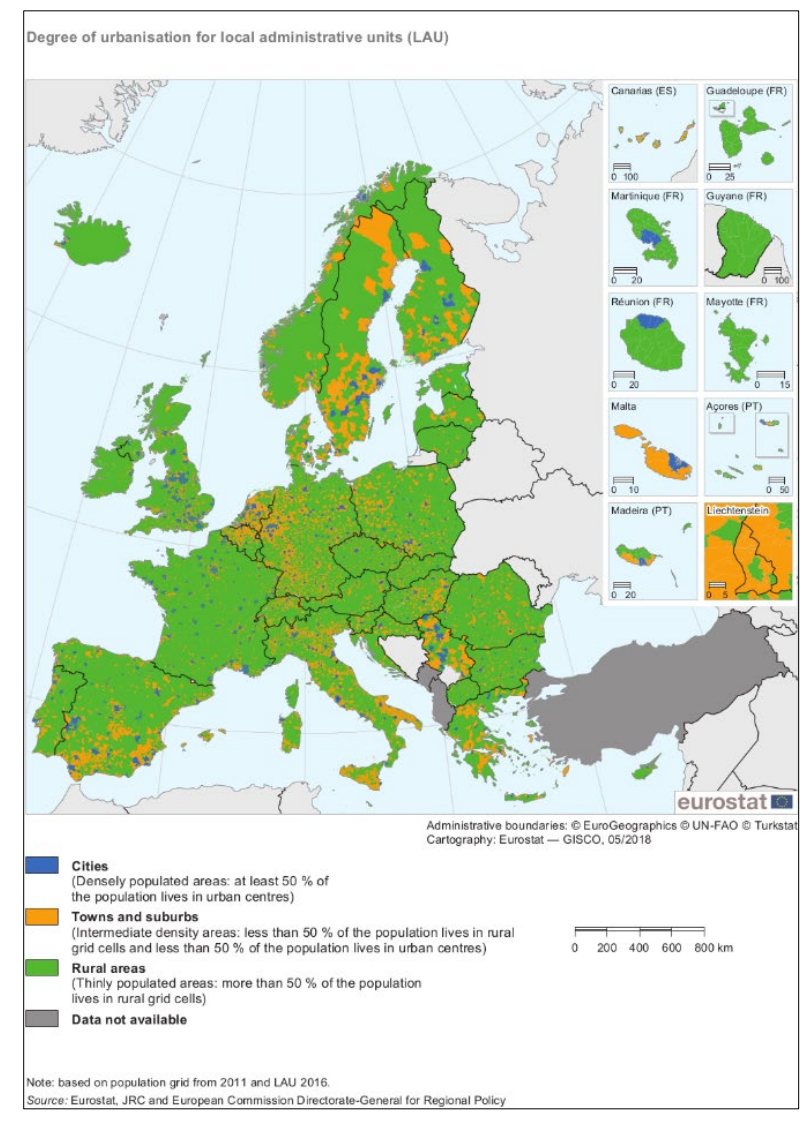

Figuur 3.7 Verstedelijking in Europa Bron: Eurostat (2016). 


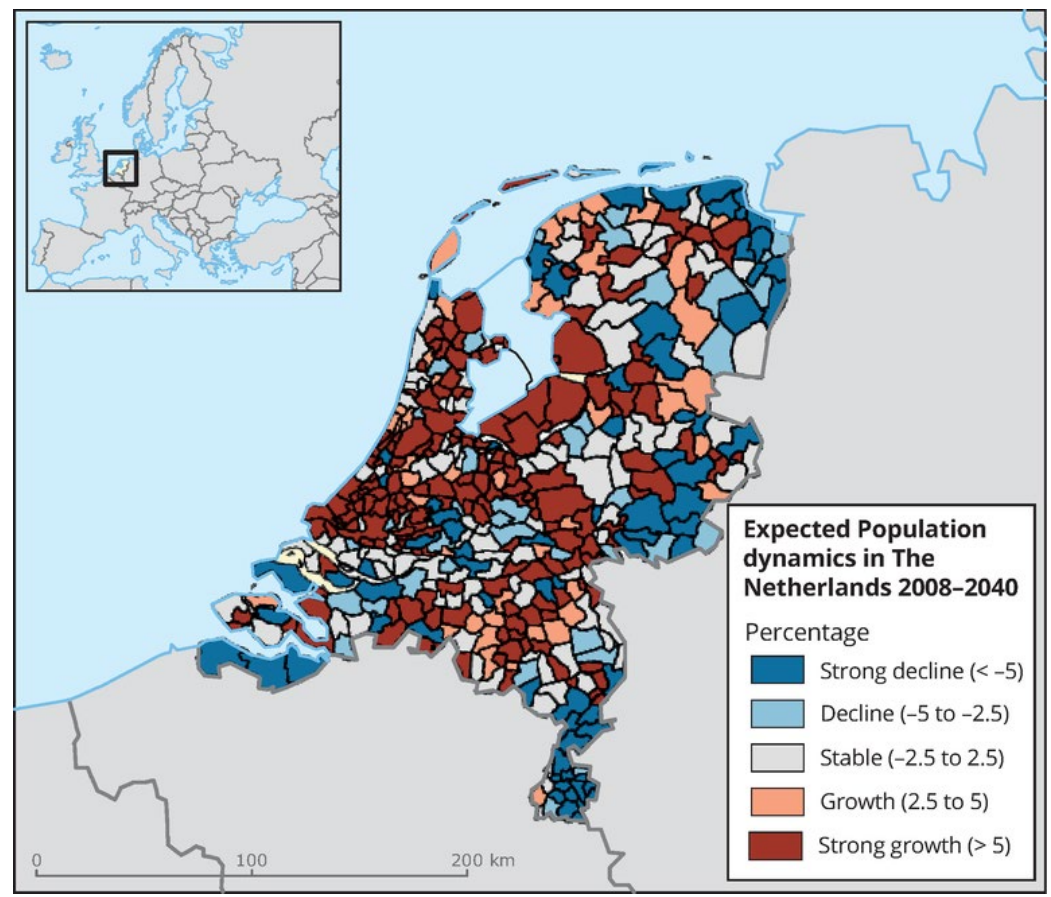

Figuur 3.8 Verwachte ontwikkeling van de bevolking voor gemeenten in Nederland. Bron: Eurostat, (2016).

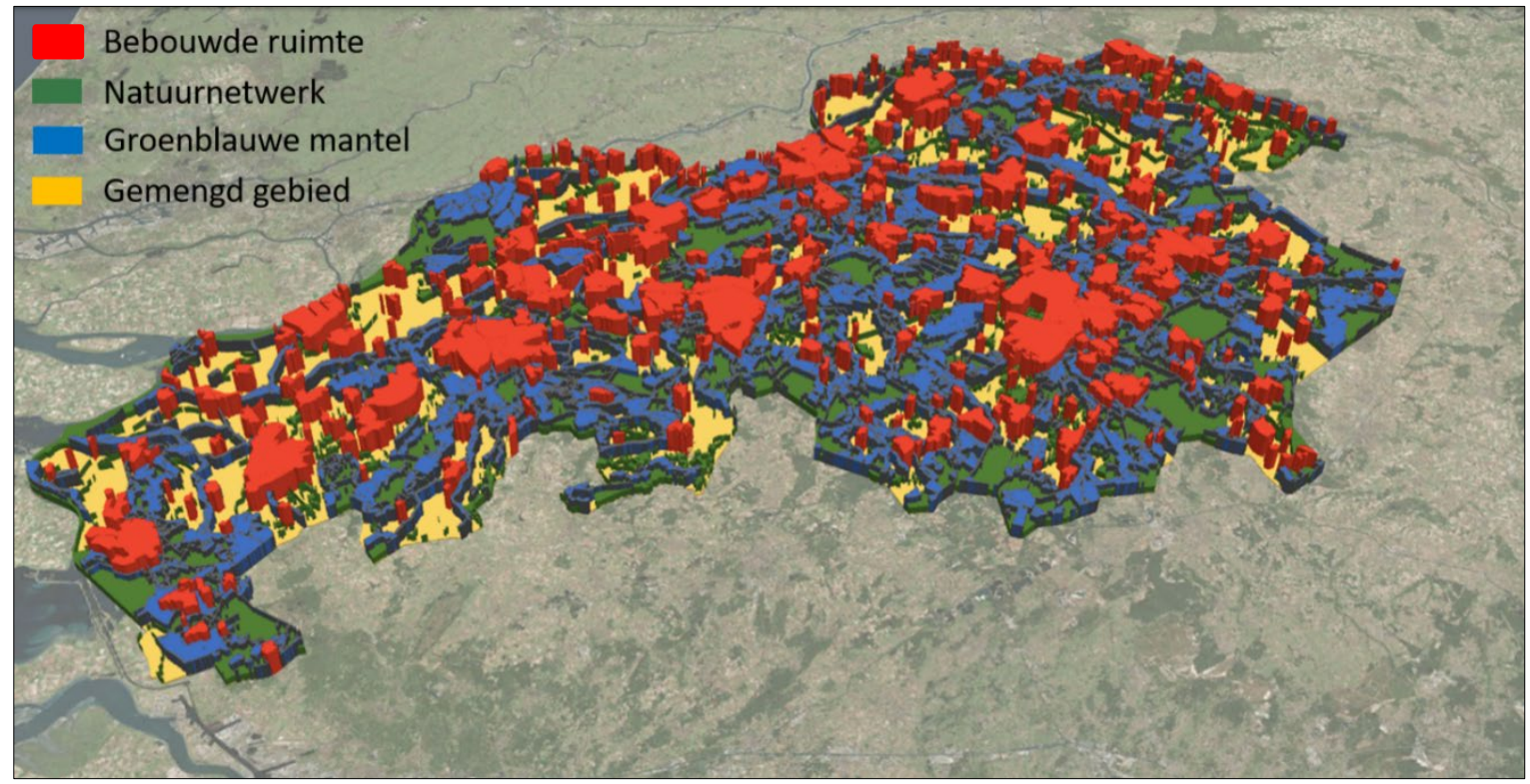

Figuur 3.9 De ruimtelijke verdeling van bebouwde ruimte, natuurnetwerken, groenblauwe mantel en gemengde gebieden in de provincie Brabant. Het patroon van nagenoeg aaneengeschakelde stedelijke gebieden is duidelijk te zien (Bron: https://climadapserv.maps.arcgis.com/apps/Cascade/index. $h$ tm/?appid=9858bf99076b4f4bba d10a92d1c7fdb5; geraadpleegd op 14 juli 2020).

De trends van een langzaam groeiende bevolking in sommige gebieden en een krimp in andere, gecombineerd met een lichte afname van het aantal personen per huishouden, leidt tot een blijvende grondvraag vanuit bebouwde ruimte. De concurrentie om de grond tussen bebouwing (inclusief wegen e.d.), natuur en landbouw zal blijven en een effect hebben op de grondprijzen.

Het PBL rapport "Quality of Life in Europe" (Lagas et al., 2014), geeft aan dat Noord Brabant hoort bij de gebieden waar de kwaliteit van leven goed wordt gewaardeerd. De "Regional Quality of Living Index" (RQI) wordt gebruikt om op 25 indicatoren, verdeeld over 9 categorieën, alle deelgebieden in 
Europa te waarderen, waaronder alle Nederlandse provincies. Nederland scoort vooral goed als het gaat om publieke diensten, recreatie en onderwijs, terwijl de scores voor sociale omgeving, gezondheid en koopkracht vergelijkbaar zijn met het gemiddelde van de top-25 van de gebieden in die categorieën. Er is een aantal indicatoren waarbij Brabant onder het Europees gemiddelde zit: natuur, huisvesting en woonomgeving. Bijna alle provincies scoorden lager als het gaat over wonen en de natuurlijke omgeving ten opzichte van de betere gebieden in Europa. Als Noord-Brabant nader wordt bekeken, zijn er geen categorieën waarbij Brabant het beste of slechtste scoort ten opzichte van de andere provincies. Noord-Brabant hoort wel tot de provincies met een lage waardering voor huisvesting, natuurlijke omgeving en gezondheid. Als het gaat om publieke diensten, koopkracht, werkgelegenheid en onderwijs scoort Noord Brabant erg goed.

\subsubsection{Productie en consumptie internationaal verknoopt}

Uit het voorgaande bleek al duidelijk dat de landbouw in Noord-Brabant, zowel plantaardig als dierlijk, sterk afhankelijk is van buitenlandse handel. Dat geldt overigens ook voor de consumptie. Het PBL (2019) heeft dat helder verbeeld in figuur 3.10. Het grijsgroene vlak linksboven verbeeldt de Nederlandse landbouwproductie, het oranje vlak rechts-midden verbeeldt de Nederlandse voedselconsumptie. De Nederlandse consumptie wordt slechts voor $26 \%$ gedekt door Nederlandse productie. De overige $74 \%$ wordt geïmporteerd, deels uit Europa (44\%), deels van erbuiten (30\%). Daarnaast verwerkt de Nederlandse Agri-food industrie slechts een deel van de Nederlandse producten, maar verwerkt het ook producten van erbuiten (het gearceerde gebed, links van het midden)

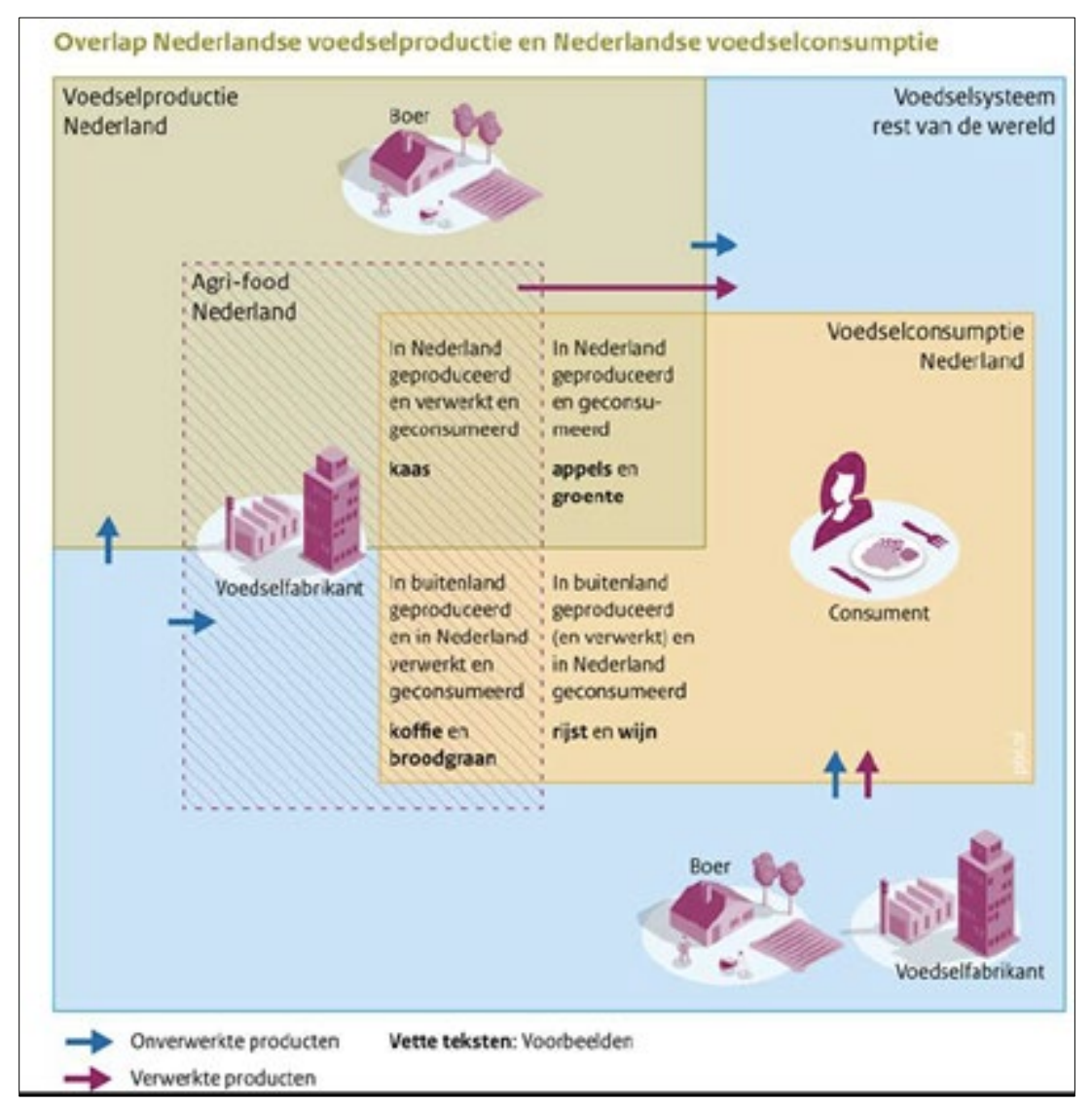

Figuur 3.10 Overlap van de Nederlandse voedselproductie en de Nederlandse voedselconsumptie. Bron: PBL, (2019).

De belangrijkste importlanden voor Nederland zijn in 2017: Duitsland, België, Polen, Verenigd Koninkrijk, Ierland, Denemarken, Frankrijk, Spanje, Italië en Brazilië. Aangezien Nederland zo sterk is verknoopt met het mondiale AFS, zullen fluctuaties in de lokale vraag naar producten slechts een zeer beperkt effect hebben op het functioneren van het Nederlandse AFS. De productie in Nederland wordt sterk beïnvloed door veranderingen in vraag en aanbod op mondiale schaal. 


\subsubsection{Marktontwikkelingen}

\section{Consumptie}

Het voedselsysteem kan een sterke invloed hebben op individuele factoren (Van Berkum et al., 2018), door onder meer de voedselomgeving. Hoewel $80 \%$ van de totale consumptie nog steeds in de huiselijke omgeving plaatsvindt (RIVM, 2018b), is er in Nederland sprake van een "obesogene" voedselomgeving, gevormd door eenvoudige toegang tot overvloedig, goedkoop en gemakkelijk voedsel (Poelmann, 2016, PBL, 2019). Dit heeft vooral invloed wat wordt geconsumeerd in de overgebleven $20 \%$. In Nederland is voedsel overal beschikbaar, supermarkten, werk, school, langs de weg, bij alle treinstations (PBL, 2019). Het biedt consumenten de gelegenheid overal alles te kopen wanneer het ze uitkomt. Lunch en avondeten worden heel vaak op of nabij de werkplek gekocht, of onderweg naar huis. In aanvulling daarop is de thuisbezorging sterk aan het groeien (CBS, 2018d; WUR, 2017), vooral in steden. Een grote rol wordt daarbij ingenomen door bezorg-apps, zoals UberEats en het Nederlandse Thuisbezorgd. Met het kleiner wordt van de huishoudens, neemt waarschijnlijk ook de trend toe om buitenshuis te eten. Dit nog even los van de huidige Corona situatie waarin het op dit moment niet mogelijk is om buiten de deur te eten.

De vraag van de Nederlandse consumenten is erg divers en aan veranderingen onderhevig, wat te maken heeft met de diversiteit van de Nederlandse bevolking en de toenemende verstedelijking. Tegelijk dient te worden bedacht dat het Nederlandse voedselsysteem maar voor een beperkt deel voor de Nederlandse consument produceert. Er is daarom verschil tussen wat in Nederland voor de wereldmarkt wordt geproduceerd en de wensen van de Nederlandse consument.

\section{Voedselverspilling}

In 2019 verspilden Nederlanders 34,3 kilo voedsel per persoon; bijna 7 kilo minder dan in 2016. Nederlanders verspilden de afgelopen jaren vooral minder brood, zuivel, groente en fruit. Bij deze producten is echter nog steeds de grootste winst te behalen. Daarnaast verspilden huishoudens ook minder vloeistoffen (koffie, thee, melk, frisdrank, sap, etc.) via de gootsteen of het toilet. In 2019 werd naar schatting 45,5 liter vloeistof per persoon weggespoeld; ruim 11 liter minder dan in 2016 $(57,3 \mathrm{l})$. Daarmee ligt Nederland op koers voor het behalen van het doel: een halvering van de voedselverspilling in 2030 (Milieu Centraal, 2019).

\subsubsection{Wetenschap en and technologie}

De hoog productieve provincie Noord-Brabant wordt ondersteund door een groot en sterk kennis- en innovatie netwerk. De private sector R\&D uitgaven in Noord-Brabant zijn het hoogste van Nederland: in 2017 bedroeg dit 2,99\% van het BNP, meer dan het dubbele van het nationaal gemiddelde van $1,15 \%$ (BOM, 2020 op basis van cijfers van CBS 2019). Dat is ook meer dan het Nederlandse en EU gemiddelde (respectievelijk 2.0 en $2.04 \%$ in 2016). Vergeleken met andere regio's binnen Europa, staat Noord Brabant op de $12^{\mathrm{e}}$ plaats van de hoogste investeerders in R\&D.

Brainport Eindhoven is de meest intensieve R\&D regio binnen Nederland en wordt grotendeels gefinancierd vanuit de private sector. Er zijn 163 bedrijven actief in deze high tech hub, waaronder Philips (gezondheidstechnologie), ASML (machines voor de halfgeleider industrie), VDL groep (een conglomeraat in onderaanneming en halffabricaten), NXP (chips fabricage), DAF (truck fabricage) en nog vele anderen. De Brainport heeft een hoge output aan patenten, ongeveer $40 \%$ van het Nederlandse totaal. Binnen Europa is het de regio met de meeste patenten. De "Automotive Campus" in Helmond is ook onderdeel van de Brainport Eindhoven, een internationale plek voor de mobiliteitssector, met 500 onderzoekers, 30 bedrijven en 25 faciliteiten voor testen.

Er zijn twee universiteiten, de Technische Universiteit Eindhoven en de Tilburg Universiteit. Tevens zijn er hogescholen, de AVANS hogeschool in Breda, Fontys in o.a. Eindhoven en de HAS Hogeschool in Den Bosch.

Ook in de landbouw en de levensmiddelenindustrie neemt Brabant een toppositie in, dankzij kennis en innovatie (PBL, 2012). In de afgelopen jaren zijn er veel initiateven ontwikkeld die bijdragen aan innovatie in de landbouw. Te denken valt aan de Agroproeftuin de Peel, het praktijkcentrum voor Precisielandbouw, de Foodtech Brainport Helmond, de Jheronymus Academy of Data Science, het 
Nederlands Centrum voor Mestverwaarding. Wageningen Universiteit en Research is als niet-Brabantse Life sciences kennisinstelling betrokken bij diverse initiatieven.

\subsubsection{Beleid}

Nederland heeft vooral een landbouwbeleid en voert in minder mate een voedselbeleid. Landbouwbeleid is deels nationaal en deels provinciaal. In het landelijk beleid worden vaak doelen geformuleerd, die voor de provincie maatgevend zijn en waarmee zij moeten werken in hun beleid. De wijze waarop nationaal en provinciaal beleid zich tot elkaar verhouden wordt hier niet beschreven. We beperken ons hier tot enkele thema's waarop nationaal en provinciaal beleid elkaar ontmoeten:

\section{Milieu en klimaat}

Het stikstofbeleid is een nationaal beleidsthema. In de provincie Noord-Brabant is dit beleid zeer relevant vanwege de hoge dichtheid aan veebedrijven en de bijbehorende emissies van ammoniak. Voor het klimaatbeleid in de komende jaren is onlangs het Klimaatakkoord vastgesteld, waarbij voor de landbouw ook doelen zijn gesteld. Het gaat bij broeikasgassen om emissies die geen directe plaatselijke effecten hebben, in tegenstelling tot de emissies van $\mathrm{N}$ en $\mathrm{P}$ naar water en lucht. De uitwerking van het klimaatbeleid moet nog komen. En aspect dat de landbouw wel direct raakt en al eerder is genoemd, is de energietransitie waarbij landbouwgrond aantrekkelijk is om grote hoeveelheden zonnepanelen te plaatsen. Voor de landbouw zelf is dit aantrekkelijk vanwege het hoge saldo en de geringe arbeidsinspanning, al hebben boeren er ook wel moeite mee om goede landbouwgrond in te zetten voor energieproductie.

De Farm to Fork strategie van de Europese Commissie (European Commissie, 2020a) heeft grote ambities geformuleerd ten aanzien van milieu en klimaat. Deze zullen moeten worden vertaald in nationale acties. De vier aandachtsgebieden van de strategie zijn: a) voorkomen van voedselverspilling en -afval; b) duurzame voedselproductie; c) duurzame voedselverwerking en distributie; en d) duurzame voedsel consumptie.

\section{Biodiversiteit}

Voor biodiversiteit zijn het Nationaal Ecologisch Netwerk (NEN) en de Natura 2000 gebieden relevant. Voor beide onderdelen is de provincie de belangrijkste partij om het uit te voeren. (Rijksoverheid, 2020; Ministerie Landbouw, Natuur en Voedselkwaliteit, 2020).

\section{Innovatie}

Het beleid in Noord Brabant is sterk verweven met de activiteiten van de Brainport regio. De Brainport is een innovatie- en onderzoekshotspot van nationaal en zelfs Europees niveau. De belangrijkste private partij is Philips. Het onderzoekterrein is breed: high-tech systemen en materialen, (zonne)energie, voedsel en voeding, levenswetenschappen en medische technologie (Europese Commissie, 2020). IN het zuidwesten van de provincie ligt de nadruk op verwerkende industrie, logistiek en toerisme. De biobased economy, met gebruik van biomassa als grondstof is een opkomende sector en krijgt toenemende belangstelling vanuit het beleid. De hoop is dat hiermee fossiele grondstoffen vervangen kunnen worden door biobased grondstoffen en dat deze biobased industrie een stevige bijdrage gaat leveren aan de regionale economie. Tegelijk is het nog niet zover, en blijkt ook dat laagwaardige toepassingen (energie, commodities als veevoer en vezels) te weinig rendement opleveren voor regionale grondstoffenproducenten.

De provincies Noord-Brabant, Zeeland en Limburg hebben gezamenlijk een Research and Innovation Strategy for Smart Specialisation for South Netherlands (RIS3) die erop is gericht om de regio aan de top te krijgen als het gaat om innovatie. De helft van de economische groei in de regio komt voort uit innovatie. De vijf kerngebieden voor RIS3 zijn: 1) High-tech systemen; 2) Chemie; 3)

Levenswetenschappen en gezondheid; 4) Logistiek; en 5) Landbouw en voedsel.

\section{Leefomgeving}

In Noord-Brabant zijn de afgelopen jaren stevige maatschappelijke discussies gevoerd over de ruimte voor landbouw, die zich met name toespitst op de (intensieve) veehouderij. Een deel van deze discussie is terug te leiden tot de impact die de landbouw heeft op de fysieke leefomgeving, bijv. geur en verandering van landschap. Daarnaast zijn er ook relaties met effecten op de gezondheid van omwonenden, zoals Q-koorts en fijnstof. Verder zijn thema's als dierenwelzijn, biodiversiteit en 
klimaat steeds hoger op de maatschappelijke agenda gekomen. Echter, de tegenstellingen in dit debat zijn ook deels versterkt door frustraties bij alle betrokkenen over de aanpak van deze problemen. Daardoor is het soms lastig om feiten en emoties in dit debat te onderscheiden en blijkt het ook niet eenvoudig om politieke en maatschappelijke consensus te bereiken over deze tegenstellingen heen.

\subsubsection{Samenvatting Sociaal economische factoren}

De bevolking van Brabant is aan het vergrijzen. Deze trend is echter niet sterker dan in Nederland of andere regio's in NWE (brabant.nl, CBS). Brabant is een verstedelijkte provincie, met een netwerk aan kleine en middelgrote steden (Eurostat, 2020). De provincie Brabant kenmerkt zich door een hoge bevolkingsdichtheid en een hoge veedichtheid (FAOstat, Eurostat, 2020).

De voedselconsumptie is internationaal verknoopt. De consumptie van de Nederlandse burger is gemiddeld voor een kwart afkomstig uit Nederland, de overige driekwart komt van buiten Nederland. Daarvan komt minder dan de helft van buiten de EU, met name de tropische producten, zoals fruit, cacao en rijst (PBL, 2019).

Bij de consumenten wordt ongeveer $80 \%$ in huis geconsumeerd, terwijl $20 \%$ buitenshuis wordt geconsumeerd. Het thuisbezorgen van maaltijden en maaltijdboxen neemt toe.

Hoewel de high-tech industrie niet primair op de landbouw is georiënteerd, is er wel sprake van een grote potentie van die industrie voor innovaties op technologisch gebied. Dit wordt gestimuleerd via diverse initiatieven.

$\mathrm{Er}$ is veel discussie over de rol van de landbouw, en met name de veehouderij met betrekking tot klimaat, milieu, biodiversiteit en volksgezondheid; er is een sterke polarisatie in het debat. Op dit moment is er sprake van actief beleid ten aanzien van de leefomgeving (inclusief volksgezondheid) als het gaat om stikstof, fosfaat en fijnstof; de biodiversiteit (Deltaplan Biodiversiteitsherstel), klimaat (Klimaatakkoord). Deels is dit nationaal beleid, deels provinciaal en deels gebiedsgericht (binnen de provincie, of over provinciegrenzen heen).

\subsection{Omgevingsfactoren}

De omgevingsfactoren betreffen vooral de biofysische context waarin het agrofood systeem functioneert. Dit betreft verschillende onderdelen die een sterke onderlinge interactie hebben, zoals klimaat, water, bodem en biodiversiteit. De interactie tussen omgevingsfactoren en voedselsysteemactiviteiten vindt voor een groot deel plaats in de primaire productie maar ook wel in andere onderdelen van de productieketen zoals verwerking, distributie, handel en consumptie (Van Berkum et al., 2018). Het gehele agrofood systeem leunt uiteindelijk op natuurlijke hulpbronnen die het fundament vormen voor plantaardige en dierlijke productie: een duurzaam gebruik van die hulpbronnen is essentieel voor een goed en langdurig functioneren (UNEP, 2016).

\subsubsection{Mineralen}

De veehouderij draagt door ammoniakemissies vanuit conventionele stalsystemen in belangrijke mate bij aan de stikstofdepositie, wat o.a. risico's oplevert in kwetsbare natuurgebieden. Gebieden met veel veehouderij, zoals o.a. in Noord-Brabant, leveren dus een grote bijdrage aan de totale stikstofemissie in Nederland. Volgens het Compendium voor de Leefomgeving (CLO), is de Nederlandse landbouw verantwoordelijk voor $46 \%$ van alle $\mathrm{N}$ depositie. Hoewel er de nodige discussie is (geweest) over de cijfers, staat wel vast dat de landbouw een grote bijdrage levert. Als gekeken wordt naar de depositie per hectare, is de emissie van NH3 het hoogst in gebieden met hoge concentraties aan intensieve veehouderij, met name varkenshouderij. De provincie Noord-Brabant heeft de hoogste veedichtheid in Noordwest Europa met 8.2 Livestock Units per hectare (Eurostat, 2019). Dit is ongeveer drie keer zoveel als het gemiddelde voor Noordwest Europa. Alleen in België worden vergelijkbare gebieden aangetroffen.

Door nieuwe stalsystemen kan de ammoniakemissie worden gereduceerd: in de intensieve veehouderij zijn gesloten stallen met luchtwassers inmiddels gebruikelijk. In de melkveehouderij zijn dergelijke systemen in verband met weidegang problematisch, en wordt vooral gekeken naar 
stalsystemen waarbij mest en urine niet bij elkaar komen (primaire scheiding). Deze stallen zijn nog niet gebruikelijk in de melkveehouderij.

Overigens is de veedichtheid niet exact hetzelfde als de intensiteit van de veehouderij: door de nog steeds toenemende productie per dier lukt het de melkveehouderij bijvoorbeeld om met minder dieren toch meer melk per hectare te produceren. Omdat de mestproductie per dier wel sterk samenhangt met de melkproductie, kan de mestproductie per hectare dus toenemen als de veedichtheid gelijk blijft of afneemt. Het principe van staldering ( $1 \mathrm{~m}^{2}$ nieuwe stalruimte bouwen kan alleen als $1,2 \mathrm{~m}^{2}$ stalruimte gesloopt wordt) leidt dus wel tot minder dieren, maar niet persé tot een lagere mestproductie en tot lagere emissies.

Dit probleem van de stikstofdepositie wordt nog versterkt door de hoge bevolkingsdichtheid van een regio, omdat die samengaat met veel NOx uitstoot vanuit o.a. verkeer en industrie. Ook bij emissies naar grond- en oppervlaktewater geldt dat de combinatie van intensieve landbouw en hoge bevolkingsconcentraties de risico's vergroten. Als voorbeeld: de overschrijding van waterkwaliteitsnormen wordt deels veroorzaakt door gewasbeschermingsmiddelengebruik in de landbouw, maar bijvoorbeeld ook door allerlei schadelijke stoffen die via het riool of via afspoeling van verhardingen in het watersysteem terecht komen.

In Figuur 3.11 is te zien dat Noord-Brabant bijna de hoogste bevolkingsdichtheid en de absoluut hoogste veedichtheid heeft van de Europese Unie. Tegelijk is te zien dat de veedichtheid in andere provincies minder groot is dan in Noord-Brabant, maar nog steeds wel groter dan in andere Europese landen.

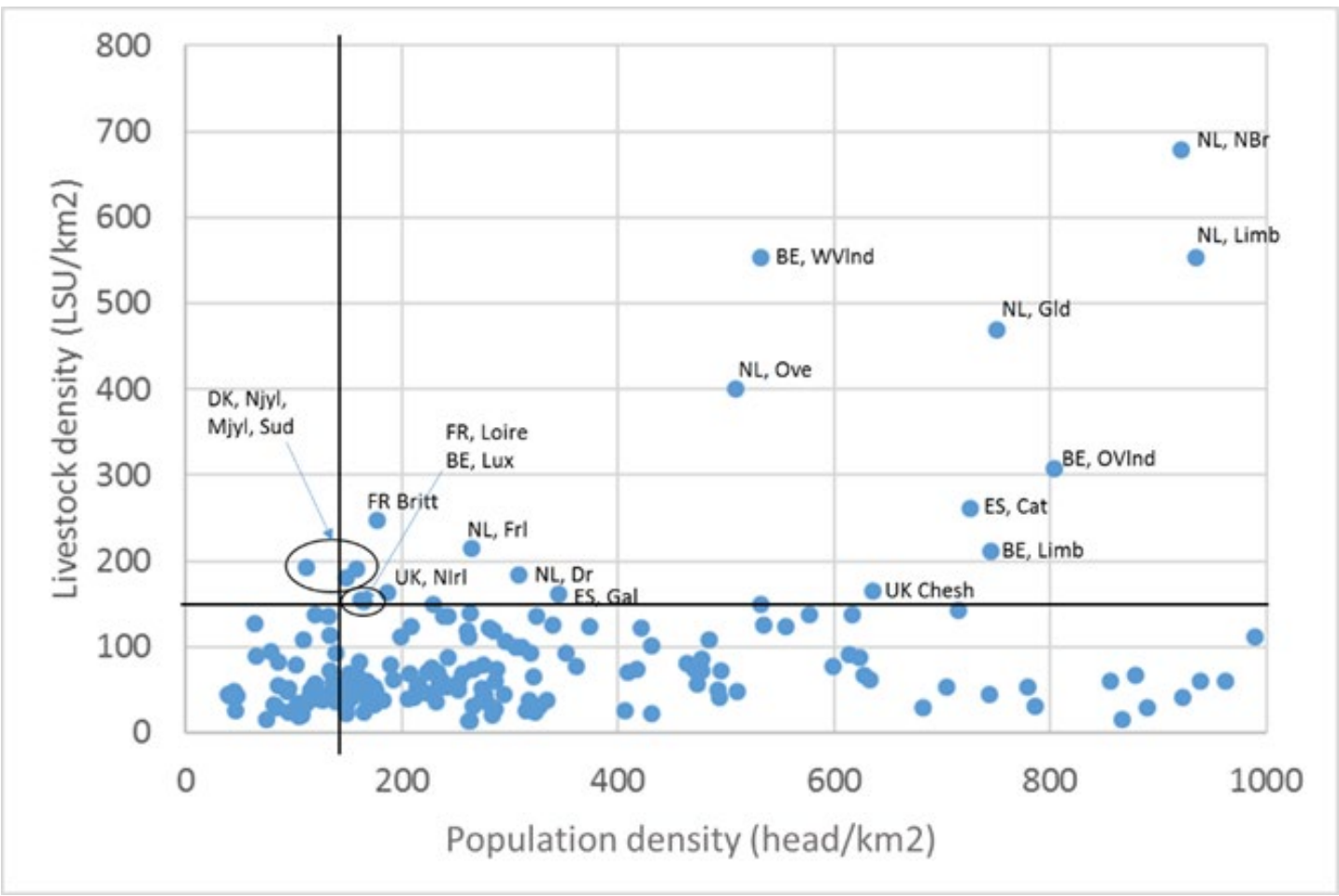

Figuur 3.11 De veedichtheid per Europese regio (provincie of deelstaat niveau) voor de EU-28 in 2014 - 2016, uitgedrukt in grootvee-eenheden (livestock units) per hectare. Bron: De Wolf et al., 2019). 
Figuur 3.12 laat zien dat de landbouw verantwoordelijk is voor bijna de helft van de stikstofdepositie in de provincie Brabant. Een aanzienlijk deel van de stikstofdepositie komt uit buitenlandse bronnen, terwijl wegverkeer en consumenten de tweede en derde belangrijke Brabantse bijdragers zijn aan de depositie.

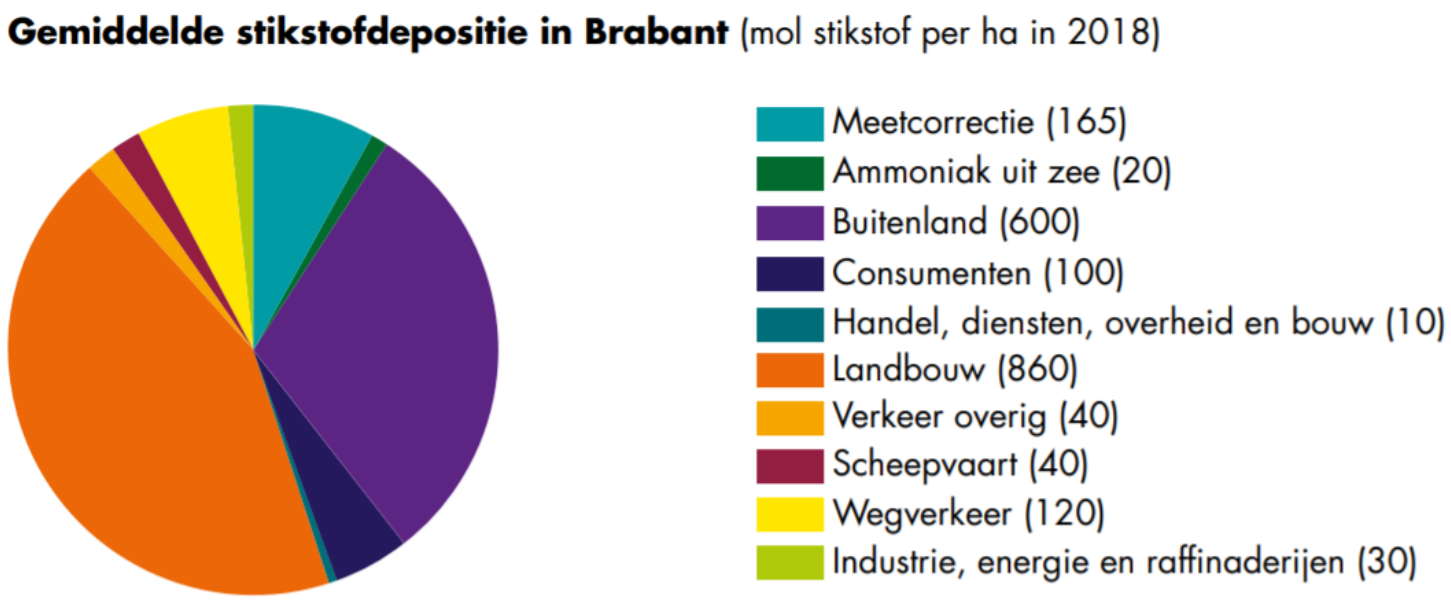

Figuur 3.12 Stikstofdepositie door verschillende sectoren in Noord-Brabant (Brabantse Ontwikkelaanpak Stikstof 1.0, uitvoeringsagenda 2020-2023).

De hoge veedichtheid zorgt niet alleen voor hoge emissies van $\mathrm{N}$ naar de lucht, ook de productie van $\mathrm{N}$ en $\mathrm{P}$ in dierlijke mest is hoog ten opzichte van het areaal, zowel op bedrijfs- als regionaal niveau. Zie ook figuur 3.13. De beschikbaarheid van dierlijke mest is dus hoog, en financieel is het aantrekkelijk om zoveel mogelijk op eigen land of in de buurt uit te rijden. De verwevenheid van sectoren, o.a. via gezamenlijk grondgebruik, zorgt er ook dat plantaardige bedrijven ook over ruim voldoende dierlijke mest beschikken.

De toediening van de dierlijke mest op bouwland en grasland wordt gereguleerd en is de afgelopen decennia ook fors beperkt, waardoor landbouwkundig overmatige toediening bij het naleven van de regels niet meer voorkomt. In het verleden is dat wel het geval geweest, wat heeft geleid tot fosfaatverzadigde gronden en lekkage van N en P naar grond- en oppervlaktewater (CLO, 2019). Echter, ook bij de huidige scherpe bemestingsnormen worden de $\mathrm{N}$ - en P-normen voor grond- en oppervlaktewater nog steeds niet gehaald. Daar zijn allerlei mogelijke oorzaken voor aan te wijzen, zoals de intensiteit van teeltsystemen (hoog aandeel risicogewassen), de uitspoelingsgevoeligheid van m.n. zandgronden, de trage emissieroutes naar grondwater etc. 


\section{Stikstof- en fosfaatproductie per landbouwgebiedsgroep, 2019}
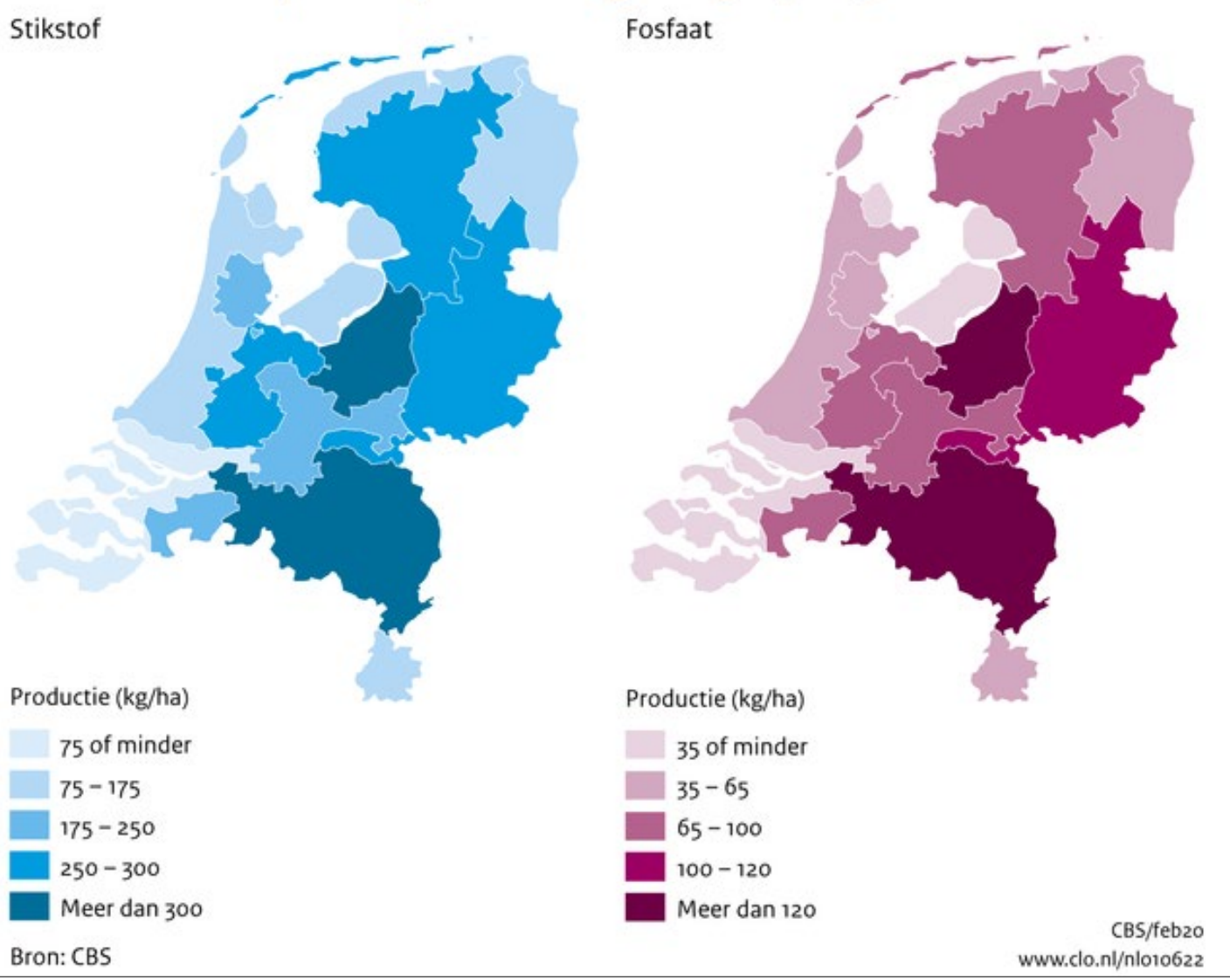

Figuur 3.13 N en P productie per landbouwgebied in 2019. Bron: CBS.nl.

Het verschil tussen de geproduceerde hoeveelheden $\mathrm{N}$ en $\mathrm{P}$ en de aangewende hoeveelheden op basis van de gebruiksruimte moet worden verwerkt. De wettelijke definitie van verwerking is a) het verwerken volgens specificaties van een afnemer en $b$ ) het exporteren van fosfaat buiten de landsgrenzen. De nadruk bij mestverwerking ligt sterk op P (en deels op $\mathrm{N}$ ) en betreft alleen het wegwerken van het overschot. $\mathrm{Er}$ is geen enkele expliciete sturing met betrekking tot de kringloop van nutriënten. Een groot deel van de mest die op dit moment verwerkt wordt, wordt geëxporteerd naar België, Frankrijk en Duitsland.

Het vinden van de juiste plaats voor de mestverwerkingsfabrieken is een probleem, omdat veel locaties in de vergunningsprocedure strandden door lokale politieke weerstand. De provincie NoordBrabant heeft daarom, mede namens de Brabantse gemeenten en waterschappen, in 2020 het initiatief genomen om deze patstelling te doorbreken.

\section{Biodiversiteit}

Biodiversiteit is een veelomvattend begrip dat verwijst naar alle verscheidenheid aan leven binnen soorten, tussen soorten en tussen de ecosystemen waartoe ze behoren (CLO, 2020).

Noord-Brabant bezit in totaal zo'n 100000 hectare aan natuur- en recreatiegebieden (CBS, 2018b). Ondanks de grote inspanningen aan het einde van de $20 \mathrm{e}$ eeuw om natuurgebieden in kwaliteit te verbeteren, te vergroten en met elkaar te verbinden, neemt de biodiversiteit nog steeds af (Brabant.nl). De ecologie in Noord-Brabant staat dus nog steeds onder druk, met meer dan 1000 planten- en dierensoorten waarvan de habitat in omvang en kwaliteit wordt bedreigd, mede door veranderend ruimtegebruik en een nog steeds hoge milieudruk (Brabant.nl).

In een rapport van het Intergovernmental Platform on Biodiversity and Ecosystem Services (IPBES, 2019) wordt gesteld dat achteruitgang van biodiversiteit een ten minste even grote bedreiging voor de mensheid is als klimaatverandering. Daarom worden zowel wereldwijd (Convention on Biological Diversity), in Europa (EU-Biodiversiteitsstrategie) als -daaraan gekoppeld- in Nederland plannen en 
doelen opgesteld en geïmplementeerd om achteruitgang in biodiversiteit te keren. De ontwikkeling van het Nationaal NatuurNetwerk, dat is gestart in 1990 en moet zijn afgerond in 2027, wordt gezien als een van de belangrijkste maatregelen om biodiversiteitsverlies te stoppen.

Omdat het behoud van soorten en ecosystemen complex is richt het beleid zich vaak op een deelset: de kwetsbare soorten en typen. Dit geldt voor soorten van de Rode Lijst, de natuur- en beheertypes van de Index-NL en de soorten en habitattypen van de Vogel- en Habitatrichtlijn (VHR). De VHR is het meest sturend in het Nederlandse natuurbeleid (Pouwels, 2020). In 2020 deed Wageningen Environmental Research een studie naar de resterende opgave na 2027 voor het bereiken van een gunstige staat van instandhouding van alle habitattypen en VHR-soorten. Dit omdat uit de evaluatie van het Natuurpact in 2017 bleek dat het voorgenomen natuurbeleid slechts zou leiden tot circa 65\% doelbereik van de VHR in 2027 (Pouwels, 2020).

In Noord-Brabant komen 148 habitattypen, habitat en vogelrichtlijnsoorten voor waarvoor een resterende opgave geldt na 2027 . Dit is $79 \%$ van alle habitattypen en soorten die een opgave hebben in Nederland. Brabant is niet alleen qua oppervlakte groot, maar kent ook een zeer divers landschap. Habitattypen en soorten waarvoor Noord-Brabant een erg grote verantwoordelijkheid heeft (VHR waarden die qua verspreiding meer dan $50 \%$ voorkomen in de provincie) zijn: zeer zwakgebufferde vennen, pimpernelblauwtje, drijvende waterweegbree en kuifleeuwerik (broedvogel). Daarnaast kent de provincie ook een grote (VHR waarden die 25-50\% voorkomen) verantwoordelijkheid voor vier habitattypen, vier habitatrichtlijnsoorten, één broedvogel en één niet-broedvogel, omdat 25-50\% van hun verspreiding momenteel in Brabant ligt. Brabant heeft een meer dan gemiddelde verantwoordelijkheid voor 68 VHR waarden die 10-25\% in de provincie voorkomen. Met name de kwaliteit van het leefgebied, of de structuur en functie zoals dit bij habitattypen wordt genoemd, dient verbeterd te worden. Daarnaast is er ook een resterende opgave m.b.t. uitbreiding van het leefgebied, zowel qua verspreiding als qua areaal. Een aantal belangrijkste drukfactoren voor ecosystemen die een hoger doelbereik in Noord-Brabant belemmeren zijn onder meer mest- en pesticidengebruik in de landbouw, stedelijke ontwikkeling, waterbeheer en klimaatverandering (Pouwels, 2020).

Brabant heeft de ambitie om in 2027 een aaneengesloten natuurnetwerk te hebben gerealiseerd. Het gaat daarbij om circa 127000 ha natuur en 1500 km verbindingszones. Zo'n 90\% hiervan wordt gevormd door bestaande natuurgebieden, zoals de Loonse en Drunense Duinen. Voor de ontwikkeling van nieuwe natuur, ontbrekende stukken die vaak in gebruik zijn voor landbouw, wordt ondersteuning geboden door het Groen Ontwikkelfonds Brabant (GOB). Het GOB heeft een interactieve kaart op haar website waarop te zien is hoever het natuurnetwerk is gevorderd en waar nieuwe natuur wordt gerealiseerd. Zie figuur 3.14.

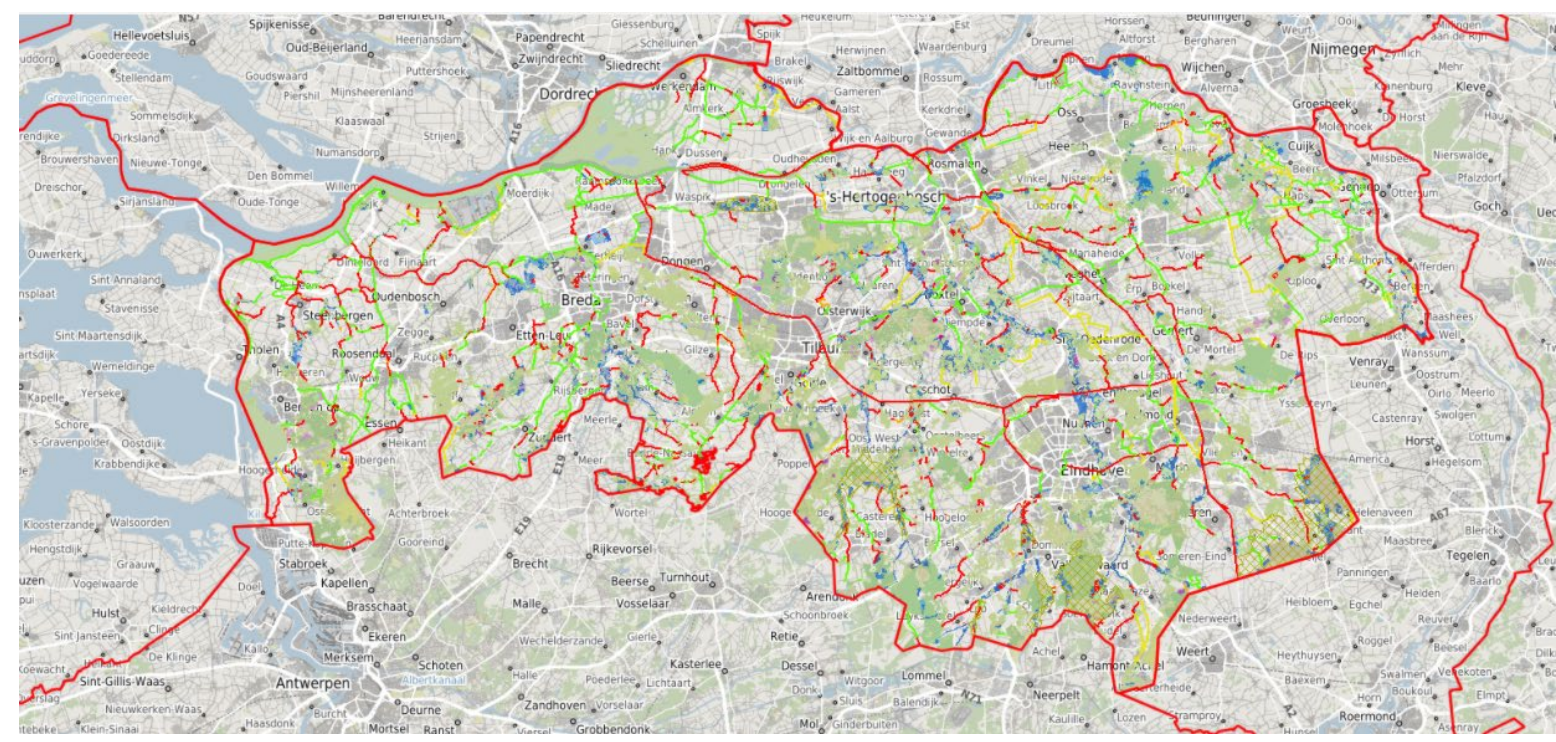

Figuur 3.14 Natuur Netwerk Brabant (www.groenontwikkelfondsbrabant.nl/kaart, geraadpleegd op 10-2-2021). 
Noord-Brabant heeft 21 Natura 2000 gebieden. Deze zijn habitats voor gevoelige en unieke dieren als de gladde slang en de noordse woelmuis (groenontwikkelfondsbrabant.nl). Volgens de website Brabant.nl zijn 14 van de 21 Natura 2000 gebieden gevoelig voor stikstof. Ammoniakemissies uit de veehouderij hebben een grote invloed op nabijgelegen Natura 2000 gebieden, in vergelijking met gebieden die verder verwijderd liggen van veehouderijconcentraties. Hoewel naast de veehouderij ook industrie, transport en personenvervoer bijdragen aan de $\mathrm{N}$ depositie (zie figuur 3.13) is de bijdrage door de veehouderij in Noord-Brabant relatief hoog. Vergelijkbare deposities zijn te vinden in de provincie Gelderland (Gies et al., 2019). In het kader van de 'Brabantse Ontwikkelaanpak Stikstof $1.0^{\prime}$ is een inschatting gemaakt van de mate van overschrijding van gevoelige delen in Natura2000 gebieden in Brabant. Zie figuur 3.15.

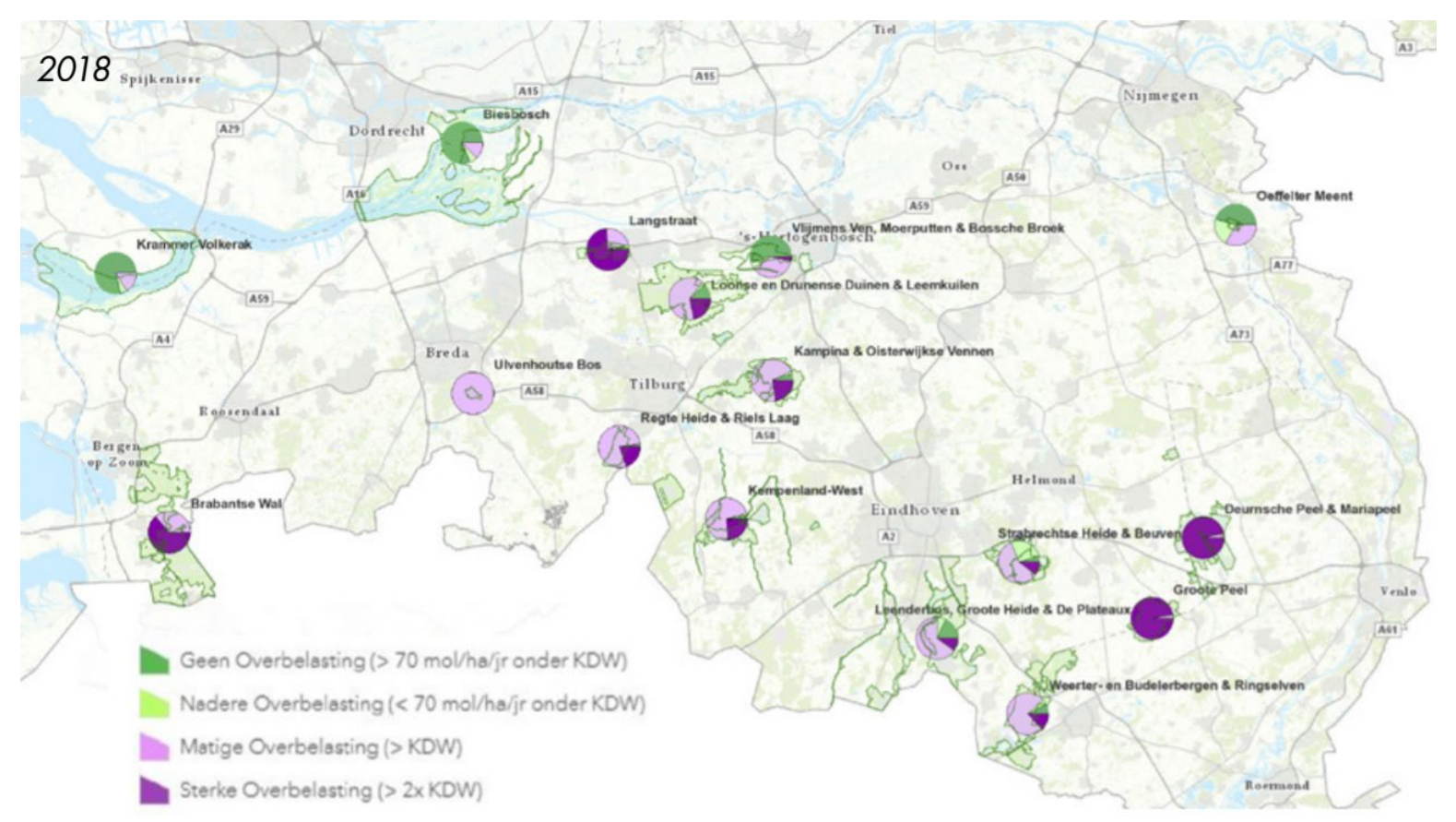

Figuur 3.15 Mate van overbelasting (stikstofdepositie) in gevoelige Natura-2000 gebieden in Brabant, cijfers van 2018 op basis van Aerius Monitor 2020 (Brabantse Ontwikkelaanpak Stikstof 1.0, uitvoeringsagenda 2020-2023).

\subsubsection{Land en bodem}

Landbouwgrond is 53 tot $60 \%$ van de totale landoppervlakte in Noordwest Europa (Tabel 2). In de landen met de lagere percentages landbouwgrond is er sprake van een groot aandeel bos en open natuurlijke terreinen. Van de landbouwgrond is het grootste deel grasland.

Als bos en natuurlijk terrein samengenomen worden, heeft Noord-Brabant daarvan een groter aandeel dan de rest van Nederland, daar tegenover staat dat er geen wetlands zijn. Worden bos, natuurlijk terrein, wetlands en open water bij elkaar geteld, dan is Brabant de regio met het kleinste aandeel van deze categorieën samen. Het percentage bebouwd gebied is in Noord-Brabant bovengemiddeld hoog ten opzichte van Nederland totaal en andere Noordwest Europese landen, met uitzondering van België wat een vergelijkbaar hoog percentage bebouwd gebied heeft. 
Tabel 2 Landgebruik in Noordwest Europa (bron: Eurostat, 2019).

\begin{tabular}{|c|c|c|c|c|c|}
\hline & bebouwing, wegen enz. & $\begin{array}{l}\text { Landbouw } \\
\text { grond }\end{array}$ & $\begin{array}{c}\text { Bos en open } \\
\text { natuurlijk terrein }\end{array}$ & $\begin{array}{l}\text { Wet } \\
\text { lands }\end{array}$ & Open water \\
\hline België & $21 \%$ & $57 \%$ & $21 \%$ & $0 \%$ & $1 \%$ \\
\hline Luxemburg & $11 \%$ & $53 \%$ & $37 \%$ & $0 \%$ & $0 \%$ \\
\hline Frankrijk & $6 \%$ & $59 \%$ & $34 \%$ & $1 \%$ & $1 \%$ \\
\hline Duitsland & $9 \%$ & $57 \%$ & $31 \%$ & $1 \%$ & $2 \%$ \\
\hline Ierland & $2 \%$ & $67 \%$ & $14 \%$ & $15 \%$ & $2 \%$ \\
\hline Nederland & $14 \%$ & $60 \%$ & $11 \%$ & $7 \%$ & $9 \%$ \\
\hline
\end{tabular}

De bodem in Noord-Brabant is beschreven in een rapport van de provincie (2014) en getoond in Figuur 3.16. De kleigronden in het noordwesten en de rivierterrassen langs de Maas zijn van natuur vruchtbaarder en kunnen meer water vasthouden dan de zandgronden in de rest van de provincie. De zandgronden bestaan hoofdzakelijk uit dekzand, arm aan mineralen en veel gevoeliger voor droogte omdat hun vermogen om water vast te houden, beperkt is. De blauwe lijnen geven de beekdalen aan, waar de zandgronden hogere grondwaterstanden hebben en rijker zijn aan mineralen. Dat is ook een gevolg van de afzetting van door de beken aangebracht materiaal. De kleigronden zijn beter bestand tegen klimaatverandering dan de zandgronden.

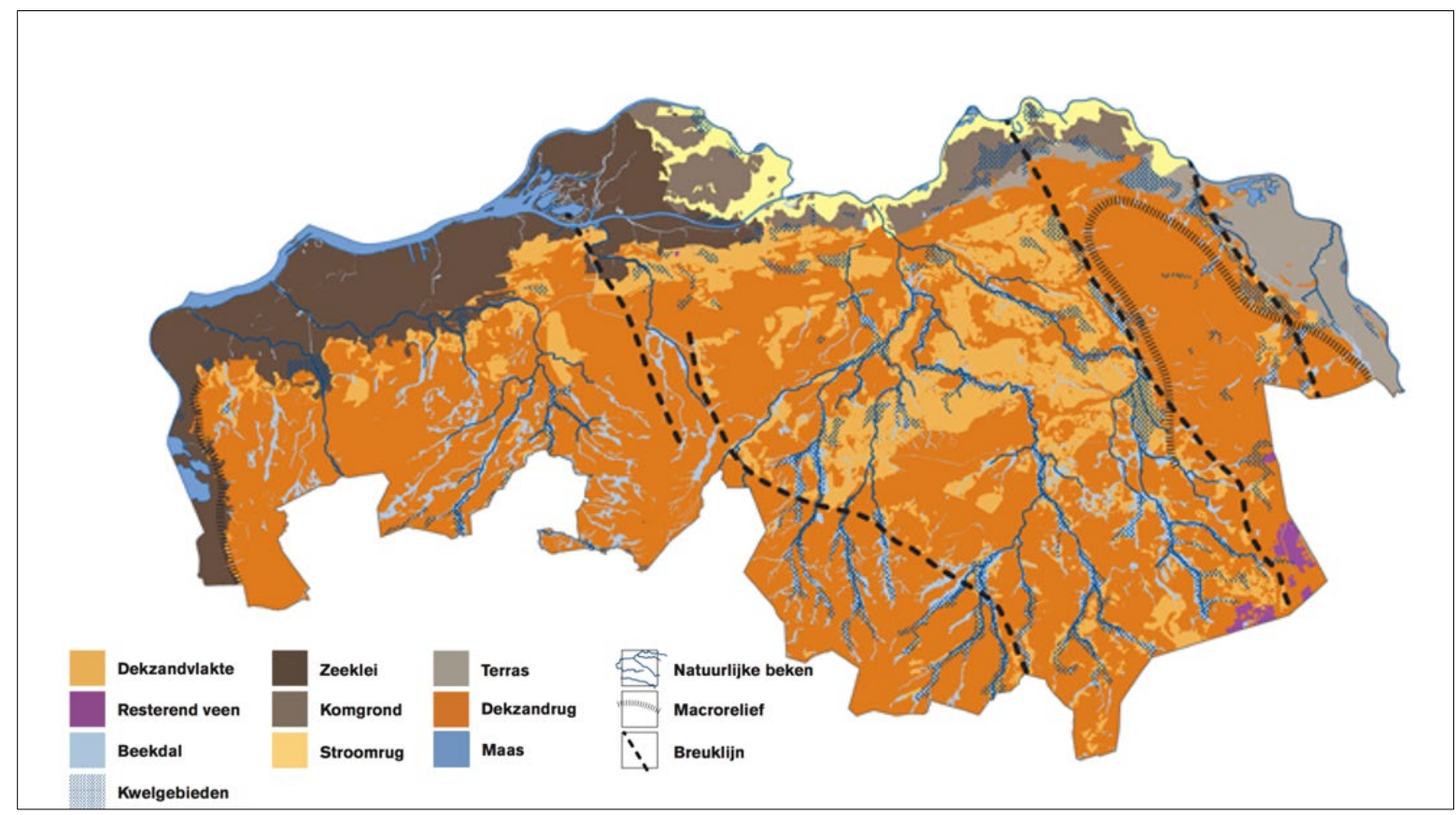

Figuur 3.16 De bodem van Noord-Brabant. Bron: Brabant.nl.

De Raad voor de Leefomgeving en Infrastructuur (RLI) heeft in de zomer van 2020 een rapport uitgebracht "De Bodem Bereikt", waar veel aandacht wordt gevraagd voor de bodemkwaliteit. In de landbouw zelf, zowel in de veehouderij als in de akkerbouw is een groeiende belangstelling voor het behoud en verbetering van de bodemkwaliteit. Het is echter lastig om helder te krijgen wat de opgaven zijn, omdat bodemkwaliteit geen eenduidig begrip is en er ook verschillende perspectieven zijn: niet alleen vanuit landbouwkundig gebruik, maar ook vanuit natuur, water en andere ecosysteemdiensten.

Voor landbouwkundig gebruik is het intensieve grondgebruik in de Nederlandse landbouw een drukfactor voor de bodemkwaliteit. Het grootste algemene probleem van intensief grondgebruik is het 
ontstaan van bodemverdichting, wat in alle grondgebonden landbouwsectoren aan de orde is. Met name diepere verdichting kan ook moeilijk ongedaan gemaakt worden. Het verstoort niet alleen de beworteling en groei van gewassen, maar draagt ook bij aan toenemende gevoeligheid voor extreem weer (droog en nat). Dat heeft ook effecten voor de omgeving, omdat het waterbergend vermogen van landbouwgrond ook bijdraagt aan de buffercapaciteit van het watersysteem op regionale schaal.

Het tweede probleem is de toename van schade door bodemgebonden ziekten en plagen, die met name in dure teelten (uitgangsmateriaal, aardappelen, groenten) veel financiële schade kunnen doen. Deze ziekten en plagen vermeerderen zich vaak snel in bouwplannen waar veel vatbare gewassen in voorkomen en komen ook met name voor op lichte gronden (lichte zavel, zandgronden). In het zuidoostelijk zandgebied van Brabant is de bodemgezondheid een grote uitdaging, door de combinatie van risicoteelten op lichte zandgronden.

De bodemvruchtbaarheid is in Nederland niet het grootste probleem, ondanks de alarmistische geluiden, ook uit de landbouw zelf dat de bodemvruchtbaarheid achteruit holt. Nederlandse landbouwgronden behoren tot de vruchtbaarste gronden ter wereld, en ook in Brabant is de bodemvruchtbaarheid hoog door jarenlang intensief gebruik van dierlijke mest. Het mestbeleid is er juist op gericht om met name de fosfaatvoorraad terug te brengen tot waarden die landbouw- en milieukundig aanvaardbaar zijn. Ook leidt de hoge bodemvruchtbaarheid in combinatie met het intensieve gebruik op zandgronden nog steeds tot overschrijding van de stikstofnormen voor gronden oppervlaktewater.

De doelen vanuit klimaatbeleid om koolstof vast te leggen in landbouwbodems staan daarom op gespannen voet met andere milieudoelen: het verhogen van de organische stofaanvoer kan juist op uitspoelingsgevoelige gronden leiden tot een stijging van de stikstofuitspoeling.

\subsubsection{Water}

$\mathrm{Er}$ is in Noordwest Europa een grote variatie aan watersystemen en waterbeschikbaarheid als gevolg van de variatie in geologische omstandigheden, geografie en klimaat. In Noord-Brabant bestaat zowel de kans op (sterke) verdroging als op wateroverlast en overstromingen. De provincie werkt aan een Regionaal Water en Bodem programma 2022-2027 (RWP). Dit programma is de opvolger voor alle watergerelateerde aspecten van het Provinciaal Milieu- en Waterplan. De ambitie van dit nieuwe RWP is dat Brabant in 2050 een klimaatbestendig en veerkrachtig water- en bodemsysteem heeft dat bestand is tegen extremen.

De jaarlijkse neerslag is redelijk verdeeld over de maanden van het jaar en de verschillen in gemiddelde temperaturen tussen de maanden bedragen vaak minder dan 10 graden Celsius. De neerslag bedraagt gemiddeld zo'n 800 millimeter per jaar, hoewel in de laatste jaren sprake is van grote droogte in voorjaar en het groeiseizoen. De toenemende droogte in het voorjaar is een gevolg van hogere voorjaarstemperaturen en niet van een afnemende neerslag (KNMI, 2020. https://www.knmi.nl/over-het-knmi/nieuws/toenameneerslagtekort-en-verdamping-in-voorjaar. Data van mei 2020).

Water wordt veel gebruikt voor beregening op de droogtegevoelige gronden. Aangezien water schaars is, kan de beschikbaarheid van water beperkingen opleggen aan de keuze van de gewassen die worden geteeld. De beter vochthoudende kleigronden in het westen van de provincie hebben een betere beschikbaarheid van zoet water. Het gebied tussen Steenbergen en Geertruidenberg wordt gedomineerd door de teelt van vollegrondsgroente en glastuinbouw. De beschikbaarheid van water maakt dit tot een zeer rendabele teelt. Op de sterk gedraineerde zandgronden elders in de provincie is het vochtvasthoudend vermogen kleiner en gaat veel water verloren door infiltratie naar dieper grondwater, oppervlakkige afstroming (run off) en verdamping. Deze gebieden zijn meer in gebruik als grasland en deels voor de teelt van voedergewassen (hoofdzakelijk snijmais).

Een aantal gebieden in Brabant, o.a. de hoge zandgronden, is extra gevoelig voor watertekorten. Daar is jaarlijks een fors aantal dagen dat het door watertekort verboden was om vanuit oppervlaktewater te beregenen, zie figuur 3.17 . 

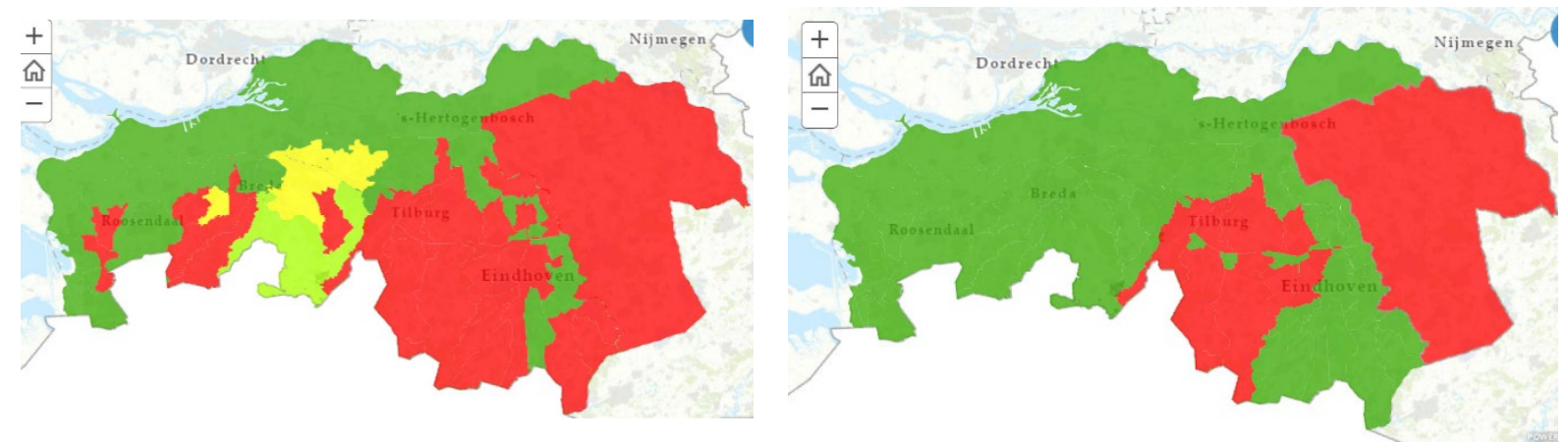

Figuur 3.17 Onttrekkingsverboden in 2015 (links) en 2016 (rechts): het aantal dagen dat het in 2015 en 2016 door watertekort in de regio verboden was om vanuit oppervlaktewater te beregenen (bron:

http://www.brabantinzicht.nl/toestand- natuur-water-en-milieu/water/ geraadpleegd 19/2/21).

Vanwege de lage grondwaterstanden en het beperkte vochthoudend vermogen is er een relatief sterke uitspoeling van nitraat naar het grondwater. Tegelijk zijn de zandgronden vaak belangrijke gebieden voor de winning van drinkwater. In Noord-Brabant wordt jaarlijks ongeveer 200 miljoen kubieke meter drinkwater onttrokken, waarnaast de industrie nog eens 20 miljoen kubieke meter onttrekt aan het diepe grondwater. In een gemiddelde zomer gebruikt de landbouw ongeveer 35 miljoen kubieke meter ondiep grondwater, wat in droge zomers kan oplopen tot 70 miljoen kubieke meter. Hierbij wordt opgemerkt dat het beeld van met name de zogenaamde kleine onttrekkingen $(<10 \mathrm{~m} 3 / \mathrm{h})$ zeer onvolledig is, en het aantal nieuwe bronnen met name de laatste jaren flink toeneemt in verband met de droogte.

Naast de hoeveelheid grondwater, is ook de kwaliteit van het grondwater een belangrijk vraagstuk. In ruim 10 procent van de gevallen (meetpunten) is er sprake van normoverschrijding door vermesting, maar overschrijdingen door verzuring, zware metalen en gewasbeschermingsmiddelen komen vaker voor. Zie figuur 3.18 .

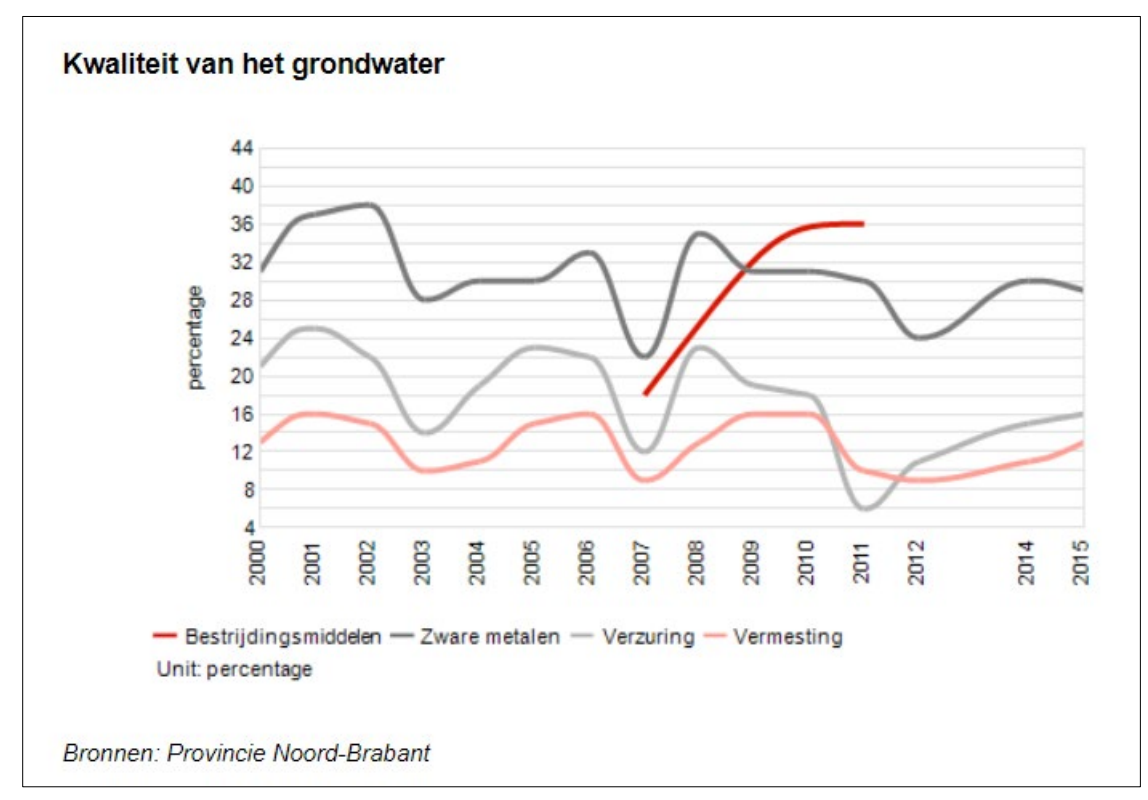

Figuur 3.18 Percentage normoverschrijdingen van de grondwaterkwaliteit in de provincie NoordBrabant. 


\subsubsection{Samenvatting omgevingsfactoren}

De provincie Noord-Brabant heeft de hoogste veedichtheid in Noordwest Europa met 8.2 Livestock Units per hectare (Eurostat, 2019). Dit is ongeveer drie keer zoveel als het gemiddelde voor Noordwest Europa. De landbouw verantwoordelijk is voor bijna de helft van de stikstofdepositie in de provincie Brabant. De hoge veedichtheid zorgt niet alleen voor hoge emissies van N naar de lucht, ook de productie van $\mathrm{N}$ en $\mathrm{P}$ in dierlijke mest is hoog ten opzichte van het areaal, zowel op bedrijfs- als regionaal niveau. Deze vormen een bedreiging voor de biodiversiteit en de (drink)waterkwaliteit.

Noord-Brabant bezit in totaal zo'n 100000 hectare aan natuur- en recreatiegebieden (CBS, 2018b). Ondanks de grote inspanningen aan het einde van de 20 e eeuw om natuurgebieden in kwaliteit te verbeteren, te vergroten en met elkaar te verbinden, neemt de biodiversiteit nog steeds af (Brabant.nl). Brabant heeft de ambitie om in 2027 een aaneengesloten natuurnetwerk te hebben gerealiseerd om biodiversiteitsverlies te stoppen. Het gaat daarbij om circa 127000 ha natuur en $1500 \mathrm{~km}$ verbindingszones. Er komen echter 148 habitattypen, habitat en vogelrichtlijnsoorten voor waarvoor een resterende opgave geldt na 2027 . Dit is $79 \%$ van alle habitattypen en soorten die een opgave hebben in Nederland. Met name de kwaliteit van het leefgebied, of de structuur en functie zoals dit bij habitattypen wordt genoemd, dient verbeterd te worden. Daarnaast is er ook een resterende opgave m.b.t. uitbreiding van het leefgebied, zowel qua verspreiding als qua areaal.

Een groot deel van de landbouwgrond in Brabant is zand, dat vaak een beperkt waterbergend vermogen heeft en daarmee droogte-gevoelig is. Ook is het gevoelig voor uitspoeling van nutriënten naar het grondwater. Water is daarom vaak een beperkende factor voor de productie. De droogteperiodes van de afgelopen jaren en de toename van de verdamping in het voorjaar in de afgelopen decennia leiden tot een groeiend tekort aan water. Zeker in regio's in Brabant waar op een aantal momenten in het jaar door watertekorten niet mag worden beregend uit oppervlaktewater kan dit tot productieverliezen in de landbouw leiden.

De productiviteit van de bodem wordt niet alleen beperkt door textuur en waterbeschikbaarheid, maar ook door de intensiteit van het grondgebruik: bodemverdichting en bodemziekten en -plagen vormen een bedreiging voor behoud of verbetering van de productiviteit. Dat geldt zowel op de zand- als de kleigronden. De zandgronden in het midden en oosten van Brabant kenmerken zich door een intensief bouwplan met akkerbouw-, tuinbouw- en ruwvoerteelten. Bodemverdichting en bodemziekten- en plagen vormen hier een grote uitdaging, evenals de waterhuishouding en de stikstofuitspoeling. De kleigronden in het westen van Brabant kennen een wat minder intensief bouwplan, hoewel ook met een relatief hoog aandeel rooivruchten. Bodemstructuur vormt hier de grootste uitdaging. Het verhogen van het organische stofgehalte om zo koolstof vast te leggen, kan leiden tot meer stikstofemissies, met name op uitspoelingsgevoelige zandgronden.

De overschotten aan mineralen door de concentratie van intensieve niet-grondgebonden veehouderij worden gereguleerd via nationale mestwetgeving. Mestverwerking brengt hoge kosten met zich mee. Het vinden van locaties voor mestverwerking (in het kader van ruimtelijke ordening) is moeilijk.

\subsection{Voedselsysteem resultaten}

\subsubsection{Voedselzekerheid}

Voedselzekerheid is één van de belangrijkste doelen van het voedselsysteem en betreft benutting, toegang en beschikbaarheid van voedsel. Het wordt ook omschreven als: "voedselzekerheid bestaat wanneer alle mensen, op elk moment, fysiek en economisch toegang hebben tot genoeg, veilig en voedzaam voedsel dat aansluit bij hun voedingsbehoeften en -voorkeuren voor een actief en gezond leven" (FAO, 2006). Nederland is één van de landen waar de voedselzekerheid op een hoog peil staat. Slechts $2.5 \%$ van de bevolking heeft te maken met ondervoeding, Nederland staat op de $9^{\mathrm{e}}$ plaats in de Global Food Security Index als het gaat om de kwestie of mensen zich het voedsel kunnen veroorloven (prijs), op de $12^{\mathrm{e}}$ plaats als het gaat om beschikbaarheid en op de $5^{\mathrm{e}}$ plaats wat betreft voedselkwaliteit en -veiligheid. De FAO ziet Nederland als een belangrijk land in het bijdragen aan 
verbetering van de voedselzekerheid in andere landen (FAO, 2020) en het is ook één van de speerpunten in het buitenlandbeleid.

\subsubsection{Volksgezondheid en voeding}

Hoewel Nederland goed scoort als het gaat om voedselzekerheid, is het eetpatroon van de Nederlanders onvoldoende gezond en duurzaam: we eten teveel, met name teveel (rood) vlees en andere dierlijke producten, zout, verzadigd vet en suiker, en te weinig groenten en fruit. Slechts $16 \%$ van de mensen eet voldoende groente en fruit (RIVM, 2018). Ongeveer de helft van de volwassen Nederlanders is te zwaar (PBL, 2019). Ongezonde voeding is naar schatting van het RIVM verantwoordelijk voor ruim $8 \%$ van de ziektelast in Nederland (RIVM, 2020), leidend tot 6 miljard euro aan zorgkosten per jaar. Daarbij zijn het onvoldoende eten van volkoren producten, fruit, groente, noten en zaden de belangrijkste factoren. Hiermee is ongezonde voeding na roken de belangrijkste risicofactor in relatie tot de ziektelast. Dit komt vooral doordat ongezonde voeding is geassocieerd met onder meer hart- en vaataandoeningen, kanker en diabetes (RIVM, 2020).

Nederland heeft een zeer diverse bevolking, afkomstig uit een groot aantal culturen en etnische achtergronden. Er is sprake van een grote variatie in voedingspatroon tussen sociaaleconomische en etnische groepen, maar ook tussen mannen en vrouwen. De gemiddelde consument nuttigt dagelijks $3.1 \mathrm{~kg}$ voedsel per dag, waarvan twee derde bestaat uit dranken (water, thee, koffie, frisdrank, zuivel en alcoholische dranken). Voedingsmiddelen waarvan meer dan 70 gram per dag wordt geconsumeerd zijn brood, zuivel, groenten, fruit en aardappelen (RIVM, 2016). Er is al geconstateerd dat de huidige consumptie niet in overeenstemming is met de richtlijnen voor gezonde voeding. Deze constatering is gebaseerd op een onderzoek in de periode 2012-2016 (RIVM, 2016). Ontwikkelingen in de voeding worden in een volgend hoofdstuk beschreven. Uit het onderzoek blijkt dat volwassenen (19-79 jaar) de richtlijnen voor alcohol en granen redelijk volgen, maar dat er te veel rood vlees, zout, vet en suikerhoudende dranken wordt geconsumeerd en te weinig groenten, fruit, en noten (Figuur 3.19).

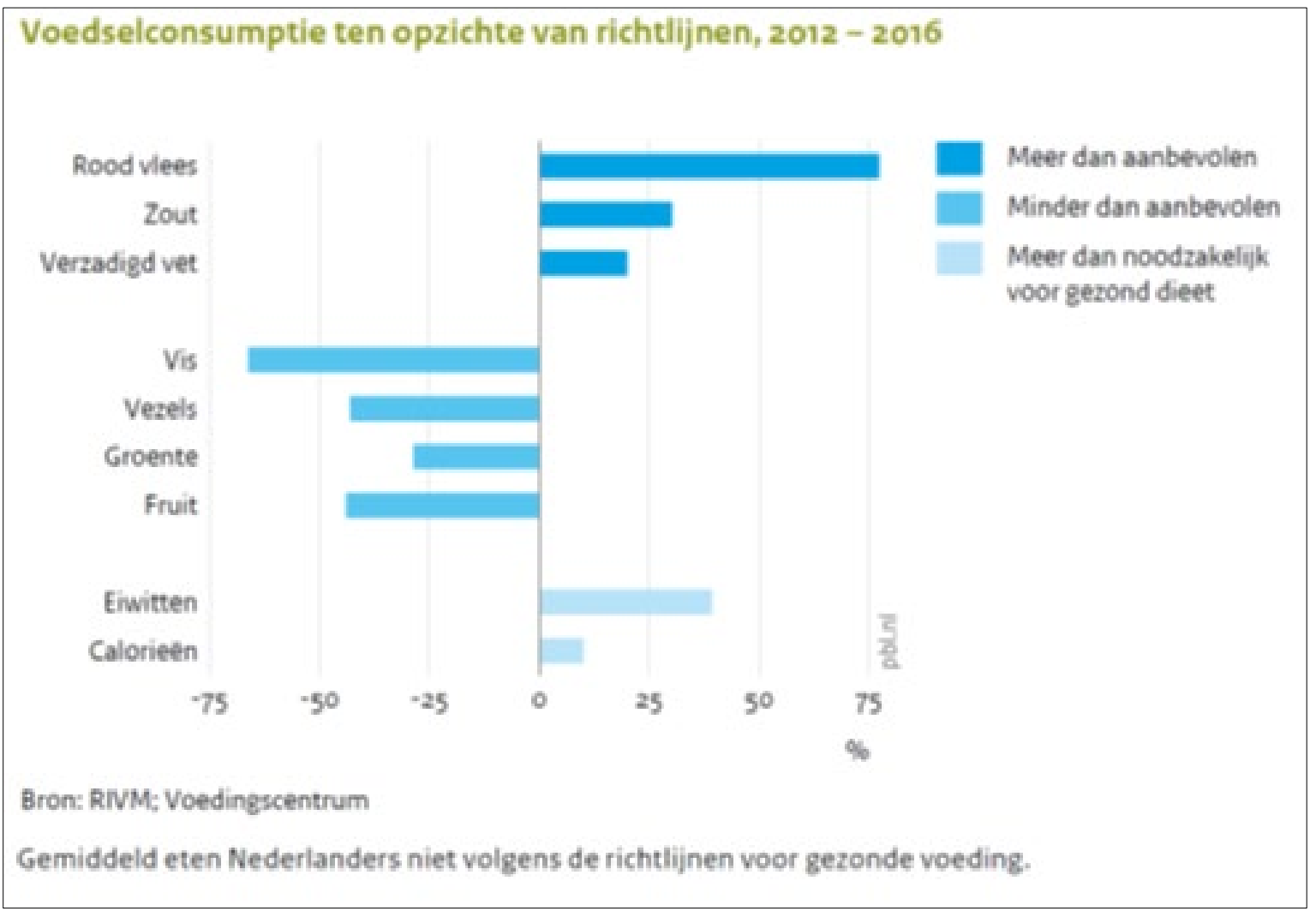

Figuur 3.19 De mate van opvolgen van de richtlijnen voor gezonde voeding voor een aantal onderdelen. Bron: RIVM, 2016. 
Er is een groeiende aandacht voor de effecten van voeding op de volksgezondheid en er wordt steeds meer aandacht besteed aan het beïnvloeden van de consumptie middels het Nationaal

Preventieakkoord. Dat akkoord richt zich op het verminderen van het roken, overgewicht en overmatig alcoholgebruik met als doel de volksgezondheid drastisch te verbeteren in 2040 (Ministerie van Volksgezondheid, Welzijn en Sport, 2018). Het zijn voorbeelden van een verschuiving naar preventieve gezondheidszorg en het "opvoeden" van de Nederlandse bevolking om meer verantwoorde keuzes te maken in hun levensstijl. Berekeningen van het RIVM van het Nationaal Preventieakkoord laten wel zien dat het aantal mensen met overgewicht zal afnemen, maar dat de ingrepen niet genoeg effect hebben om de gestelde doelen van 2040 te bereiken (RIVM, 2018). Het Preventieakkoord is slechts een eerste stap in de richting van anders denken over voeding en preventieve gezondheidszorg.

\subsubsection{Overige effecten volksgezondheid}

Verder is het effect van veehouderij op de volksgezondheid een punt van aandacht, zeker vanwege het grote economische belang en omvang van de veehouderij in Noord-Brabant. Het gaat dan enerzijds om luchtwegaandoeningen van bewoners in de omgeving van de veehouderij en het verdere effect van de veehouderij op de leefomgeving. Het RIVM (2017) geeft aan dat in de directe omgeving van veehouderijbedrijven minstens 200 gevallen (van de 1650 per 100000 inwoners) van longontsteking toegeschreven kunnen worden aan geiten- en pluimveebedrijven. Verder hebben personen die dichtbij concentraties van minstens 15 bedrijven wonen, slechtere longfuncties, zeker als de concentratie aan ammoniak hoog is. De afstand tot de bedrijven doet er dan minder toe. Naast de luchtweginfecties hebben zoönosen, met name de Q-koorts, een grote impact gehad in Noord-Brabant in de periode 2007 - 2011. Naar aanleiding daarvan zijn maatregelen getroffen en sinds 2016 zijn geen geitenbedrijven als besmet aangemerkt door de NVWA (kennisplatformveehouderij.nl/q-koorts). Deze invloeden op de volksgezondheid hebben geleid tot sterk negatieve sentimenten ten aanzien van veehouderij in het algemeen.

Niet alleen de veehouderij heeft effect op de volksgezondheid. Ook het gebruik van bestrijdingsmiddelen in de plantaardige productie is een bron van maatschappelijke zorg. Hoewel daar nog veel onduidelijk is, wordt het grote gebruik in met name de bollenteelt en akkerbouw als een potentieel gevaar gezien. De Gezondheidsraad adviseert om het gebruik van chemische bestrijdingsmiddelen te beperken in het Vervolgadvies gewasbescherming en omwonenden (Gezondheidsraad, 2020). Ook de Europese Farm to Fork strategie zet in op reductie van bestrijdingsmiddelengebruik. Daarnaast zet de sector zelf ook in op een reductie van gebruik, emissies en residuen (Actieprogramma Plantgezondheid 2020).

\subsubsection{Samenvatting voedselsysteemresultaten}

Hoewel de agrofood sector in Brabant groot is en dus ook zorgt voor veel werkgelegenheid en economie, moet ook worden geconstateerd dat het huidige agrofood systeem maatschappelijke kosten heeft gerelateerd aan gezondheidskosten en milieukosten (bijv. kosten van de stikstofmaatregelen / stoppersregeling voor veehouders). Een recente schatting geeft aan dat de maatschappelijke kosten voor gezondheid, economie en milieu van het mondiale voedselsysteem 12 biljoen dollar bedragen; 20\% meer dan de marktwaarde ervan (Pharo et al, 2019). Voor Brabant, en voor Nederland zijn er geen cijfers.

Hoewel voedselzekerheid in Nederland nauwelijks een zorgpunt is, is wel sprake van een ongezond consumptiepatroon door Nederlanders. De helft van de volwassen Nederlanders is te zwaar, en heeft daardoor een grotere kans op gezondheidsproblemen. Ongezonde voeding is naar schatting van het RIVM verantwoordelijk voor ruim $8 \%$ van de ziektelast in Nederland (RIVM, 2020. Nationaal Kompas Volksgezondheid, https://www.volksgezondheidenzorg.info/onderwerp/voeding/cijfers-

context/gevolgen\#node-ziektelast-voeding. Datum van publicatie: 13-10-2020.), leidend tot 6 miljard euro aan zorgkosten per jaar. Voor Brabant zijn geen specifieke cijfers bekend maar aangenomen kan worden dat deze getallen niet afwijken van de cijfers op nationaal niveau. 
De Brabanders zijn tevreden met hun woonomgeving, hoewel de scores m.b.t. huisvesting, kwaliteit van de leefomgeving en gezondheid lager zijn dan gemiddeld in Europa. De hoge veedichtheid leidt in een aantal gevallen tot problemen m.b.t. volksgezondheid, het gaat dan om luchtwegaandoeningen (RIVM, 2017). Daarnaast hebben zich incidenten voorgedaan met zoönosen, zoals de Q-koorts. Ook reductie van het gebruik van chemische bestrijdingsmiddelen krijgt meer aandacht.

Voor wat betreft de milieukundige resultaten (bodem, water, biodiversiteit, klimaat, etc): mondiaal gaat het agrofood systeem over vier planetaire grenzen heen: biodiversiteit, klimaat, nutriëntencycli, land- en watergebruik. Het Brabantse agrofood systeem is sterk verbonden met het Europese en mondiale agrofood systeem. Ook in Brabant speelt een aantal gerelateerde uitdagingen op het gebied van onder meer biodiversiteit, emissiereductie, klimaatdoelstellingen. Voor stikstof, bijvoorbeeld, is een reductieopgave vastgelegd in de Brabantse Ontwikkelaanpak Stikstof. 


\section{Context: maatschappelijke opgaven in de agrofood sector}

De landbouw- en voedsel sector in Nederland is een zeer innovatieve sector met een grote bijdrage aan onze economie. Tegelijkertijd zijn onze huidige voedselconsumptie en -productiepatronen sterk gerelateerd aan een aantal urgente en mondiale duurzaamheidsopgaven op het gebied van gezondheid en welzijn van mens, dier en planeet. In dit hoofdstuk worden enkele maatschappelijke vraagstukken beschreven die impact hebben (en verder gaan krijgen) op de manier waarop we voedsel produceren en consumeren.

\subsection{Mondiale en Nederlandse maatschappelijke opgaven}

Mondiaal draagt het voedselsysteem direct bij aan een sterke overschrijding van vier planetaire grenzen: klimaatverandering, verlies aan biodiversiteit, niet duurzaam land- en watergebruik en gebroken stikstof- en fosfaatcycli (Rockstrom, 2009; EAT Lancet, 2018; IPCC, 2019; IPBES 2019). Zes van de elf risicofactoren voor ziekte en mortaliteit zijn gerelateerd aan voedsel (Glopan, 2016; EAT Lancet, 2018). Bovendien is het huidige voedselsysteem onvoldoende sociaal rechtvaardig: zowel binnen als buiten Europa zijn er zorgen over de lonen en arbeidsomstandigheden in voedselketens. Boeren zijn in toenemende mate locked-in het systeem door toegenomen specialisatie (en investeringen) in één product, één productiewijze en één afzetmarkt. Daarbij zijn voedselketens primair gericht op kwantiteit, standaardisatie en de laagste kostprijs. Maatschappelijke kosten, zoals zorgkosten door ongezonde voedingspatronen, dierenwelzijn (Visseren-Hamakers, 2020), uitbraken van infectieziekten en milieukosten, zoals nu in Nederland kosten voor het aanpakken van de stikstofcrisis en klimaatmaatregelen, zijn niet opgenomen in de productprijzen (Baltussen et al, 2017). Een recente schatting geeft aan dat de gemonetariseerde maatschappelijke kosten voor gezondheid, economie en milieu van het mondiale voedselsysteem 12 biljoen dollar bedragen: 20\% meer dan de marktwaarde van voedselsystemen (Pharo et al, 2019).

Ook het Nederlandse voedingspatroon is onvoldoende gezond en duurzaam; we eten teveel, met name teveel (rood) vlees en andere dierlijke producten, zout, verzadigd vet en suiker, en te weinig groenten en fruit. Ongeveer de helft van de volwassen Nederlanders is te zwaar (PBL, 2019).

Ongezonde voeding is naar schatting van het RIVM verantwoordelijk voor ruim $8 \%$ van de ziektelast in Nederland (RIVM, 2015), leidend tot 6 miljard euro aan zorgkosten per jaar. Ook de productie van voedsel is in Nederland nog niet klimaatneutraal/-positief, onvoldoende circulair en legt grote druk op bodem, water, lucht en biodiversiteit, ook elders in de wereld. Nederland exporteert niet alleen bijna driekwart van het voedsel dat de Nederlandse landbouw produceert; we importeren ook veel. De landbouwgrond die voor de Nederlandse voedselproductie wordt gebruikt, ligt voor $74 \%$ in het buitenland, waarvan $44 \%$ in Europa (PBL, 2019). Dit leidt tot een grote disconnect tussen productie en consumptie, en daarmee ook tussen producenten en consumenten.

Op het niveau van de provincie Noord-Brabant zijn geen specifiekere cijfers bekend, maar de aanname is gerechtvaardigd dat de conclusies ook gelden op provinciaal niveau: voedselproductie zorgt voor een hoge belasting van de leefomgeving, het voedingspatroon is onvoldoende gezond en duurzaam, een groot deel van het voedsel wordt buiten de provincie geproduceerd en de provinciale voedselproductie wordt voor een groot deel buiten de provincie afgezet. Ook in Brabant is dus geen directe relatie tussen productie en consumptie, en evenmin tussen producenten en consumenten. Er is wel een kleine groei te zien in het aantal 'korte ketens', ook in Brabant, zie verder paragraaf 5.1.1. 


\subsection{Transitieopgaven productie en consumptie}

Bovengenoemde duurzaamheidsopgaven zijn geen losstaande problemen; het zijn gerelateerde symptomen van een niet-duurzaam voedselsysteem. De vereiste veranderingen zijn complexer dan het aanpassen van een onderdeel van het systeem (bijvoorbeeld landbouwpraktijken) of symptoombestrijding (bijvoorbeeld verwaarden van voedselverspilling) en liggen op verschillende gerelateerde deelsystemen die zijn verankerd in de maatschappelijke structuur, cultuur en werkwijzen. Het is daarom evident dat het niet voldoende is om het huidige voedselsysteem te verduurzamen; veel partijen pleiten voor een fundamentele transitie van het voedselsysteem als geheel (IPES Food, 2015; IPBES, 2019). Ook de Nederlandse ministers van LNV en BZ stelden in hun kamerbrief over voedselzekerheid (Kaag en Schouten, 2019 p.4-5): "het huidige voedselsysteem is [...] een bedreiging voor zowel mensen als de planeet. Transformatie van dat systeem is een absolute voorwaarde om de Sustainable Development Goals en het klimaatakkoord van Parijs te realiseren".

Dit beeld wordt bevestigd door het Planbureau voor de Leefomgeving in hun "Inzichten uit mondiale milieuverkenningen; lessen voor Nederland" (PBL, sept 2020) waarin ze constateren: versnelde actie en radicale veranderingen in productie en consumptie (oftewel transities) zijn vereist om verdere milieudegradatie te stoppen en internationaal afgesproken doelen te halen. Deze boodschap is niet nieuw. Wel is de resterende tijd om de afgesproken ambities in actie om te zetten het afgelopen decennium aanzienlijk geslonken en daarmee ook de flexibiliteit in mogelijke oplossingen.

De EU Farm to Fork strategie speelt in op deze urgentie door te stellen: We need to redesign our food systems which today account for nearly one-third of global GHG emissions, consume large amounts of natural resources, result in biodiversity loss and negative health impacts (due to both under-and over-nutrition) and do not allow fair economic returns and livelihoods for all actors, in particular for primary producers. (ec.europa.eu/food/farm2fork). In deze strategie wordt dan gekozen voor een integrale voedselsysteem aanpak; niet alleen gericht op landbouw. Zie figuur 4.1.

Ook een beleidsstuk als Waardevol en Verbonden (LNV, 2018) richt zich o.a. op kringlooplandbouw. Maar PBL constateert dat meer onderliggende samenhang en concretisering van de transitieagenda nodig is (PBL, 2020). Onder de vlag van de Nationale Wetenschaps Agenda (NWA) start per 1 maart 2021 het project 'Transitie naar een duurzaam voedselsysteem' door een coalitie van 30 wetenschappers (WO en HBO) en 20 werkveldpartijen die gaan samenwerken aan o.a. een versnellingsagenda voor transitie van het voedselsysteem. HAS Hogeschool is daarvan de penvoerder.

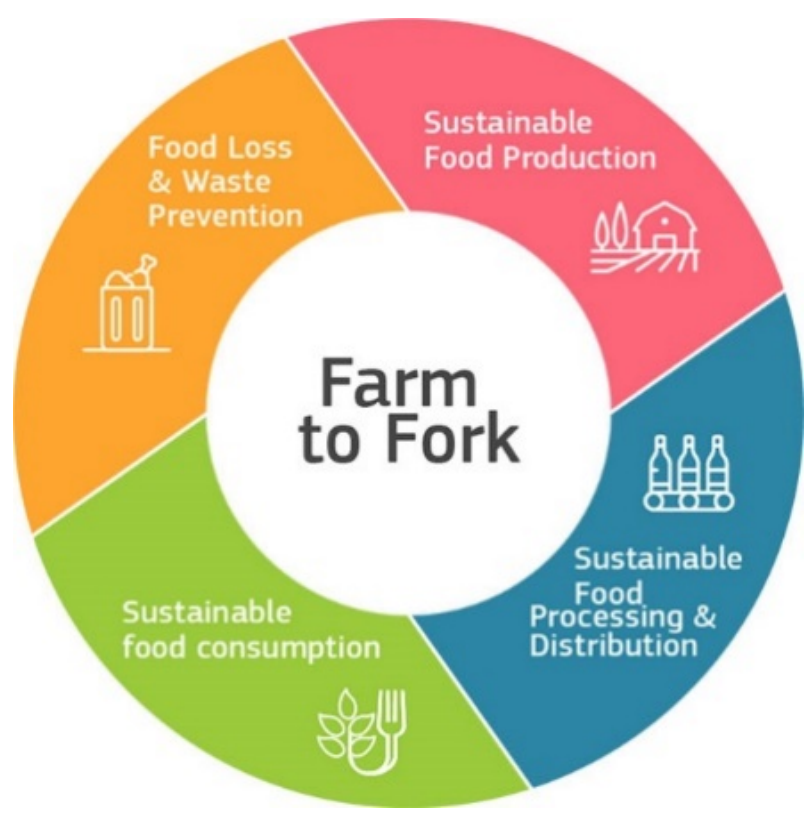

Figuur 4.1 De EU Farm to Fork strategie met voedselsysteem doelstellingen. 


\subsection{Opgavegerichte innovatie vergt ander beleid}

De transitieagenda past bij het streven naar missiegedreven innovatie: innovatie gericht op maatschappelijke opgaven door samenwerking van wetenschappers met bedrijven, overheden én maatschappelijke partijen (Rathenau, 2019). Nederland heeft in het algemeen een innovatieve cultuur en een ruim 120-jarige geschiedenis van coöperatief ondernemerschap. Dat vertaalt zich in veel vernieuwing en nieuwe coalities: partijen die in de praktijk al aan (deelaspecten van) een voedseltransitie werken. Bijvoorbeeld nieuwe businesspartijen die op de eiwittransitie, korte ketens of true pricing actief zijn, en partijen die samenwerken aan thema's als biodiversiteit of kringlooplandbouw. Gezien de omvang van de opgaven en de schaal waarop het landbouwvoedselsysteem is georganiseerd, is het wenselijk dat de provincie de samenwerking versterkt met andere regio's om de transitie te bevorderen. De provincie Noord-Brabant heeft in zo'n samenwerking veel te bieden, zoals een aantal grote ketenspelers, innovatieve ondernemers, samenwerkingsverbanden (bijv Agrofood Capital), proeftuinen (bijv Agroproeftuin de Peel) en kennispartijen. Tegelijk kan aansluiting gezocht worden bij o.a. Food Valley (Gelderland), Mineral Valley (Overijssel), Boerderij van de Toekomst (Flevoland), etc.

Echter, onderzoek van het Rathenau Instituut naar het huidige innovatiebeleid in Nederland laat zien dat met het toevoegen van maatschappelijke missies als extra oriëntatiepunt nog maar een eerste stapje is gezet naar een nieuw genre van 'opgavegericht' innovatiebeleid. Het missiegedreven topsectoren- en innovatiebeleid, bijvoorbeeld, blijft in essentie gericht op het stimuleren van sleuteltechnologieën en van bedrijven om (al dan niet in samenwerking met kennisinstellingen) innovatieve producten en diensten te ontwikkelen. Het kabinet positioneert de maatschappelijke opgaven daarmee in de eerste plaats als economische kansen voor bedrijven. Die logica zien we ook terug in het Nationaal Groeifonds. De focus op technologieontwikkeling en bedrijven is passend als het doel is om de concurrentiekracht van bedrijven in Nederland te versterken in dienst van economische groei, werkgelegenheid en welvaart. Voor maatschappelijke opgaven zoals het klimaatbestendig maken van Nederland is echter ook een andere beleidsaanpak nodig (Rathenau, 2020).

Een aantal aspecten is voor die andere beleidsaanpak van belang:

1. Opgavegerichte innovatie is per definitie gericht op structurele veranderingen in de samenleving, ofwel transities. Transities hebben patronen van opbouw maar ook van afbraak, zie figuur 4.2 .

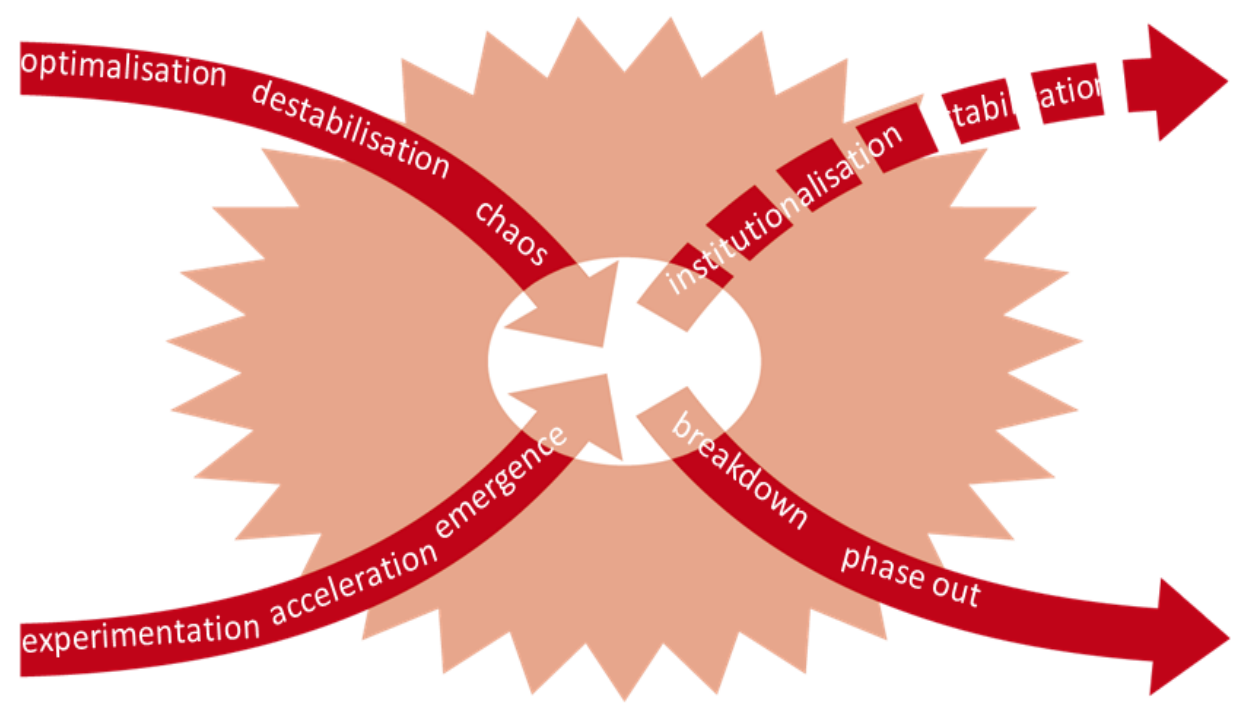

Figuur 4.2 X-curve van transities: patronen van opbouw en van afbraak. Zichtbaar op het niveau van een systemen, sectoren, organisaties en personen (Loorbach, 2012). 
Innovatie gebeurt dus in een dynamische maatschappelijke context waarin allerlei belangen en waarden met elkaar botsen. Gevestigde belangen staan op het spel, bijvoorbeeld in de stikstofcrisis waarin boeren en overheid lijnrecht tegenover elkaar staan. De maatschappelijke opgaven moeten gerealiseerd worden in een krachtenveld van uiteenlopende opvattingen, verwachtingen en (deel)belangen van bedrijven, onderzoekers, overheden en burgers. Daarmee krijgt opgavegericht innovatiebeleid dus een sterkere politieke lading dan het klassieke innovatiebeleid. Dit beleid kan zich daarom niet afsluiten voor de maatschappelijke dynamiek (Rathenau, 2020).

\section{Transities vergen een systeemaanpak}

Een transitie is een fundamentele verandering van de structuur (institutionele, fysieke, economische structuur), de cultuur (gedeelde beelden, waarden, paradigma's), en werkwijzen (routines, regels, gedrag) van een systeem (Rotmans, 2005). Een transitie van het voedselsysteem bestaat uit meerdere, deels overlappende, sub-transities en is verbonden met transities in andere systemen als water en klimaat. Inzichten uit de systeemtheorie helpen om zicht te krijgen op mogelijkheden voor transitie in een complex systeem als het voedselsysteem. Een belangrijk inzicht is dat de uitkomsten of symptomen (events) van een systeem bepaald worden door onderliggende gedragspatronen (patterns) en interacties, waarbij die patterns gekoppeld zijn aan systemische structuren (systemic structures) zoals biofysische condities, de ontwikkeling van agrarische grondprijzen, markten en wetgeving, die op hun beurt weer worden bepaald door de mental models of paradigma's zoals overtuigingen, tradities, of (culturele) waarden (Maani \& Cavana, 2007; zie figuur 4.3). Met name de mental models, de onderste laag in figuur 4.3, bepalen de structuren en de besluitvorming van een systeem of houden deze in stand. De symptomen van het voedselsysteem (de events in figuur 1.1), bijvoorbeeld voedselverspilling of biodiversiteitsverlies, zijn slechts het topje van de ijsberg, maar omdat ze heel zichtbaar zijn krijgen ze veel (politieke) aandacht. Voor de onderliggende patronen, structuren en paradigma's die maken dat de symptomen steeds maar weer ontstaan is juist weinig maatschappelijke én wetenschappelijk aandacht (IPBES, 2019; Wallace et al, 2015).

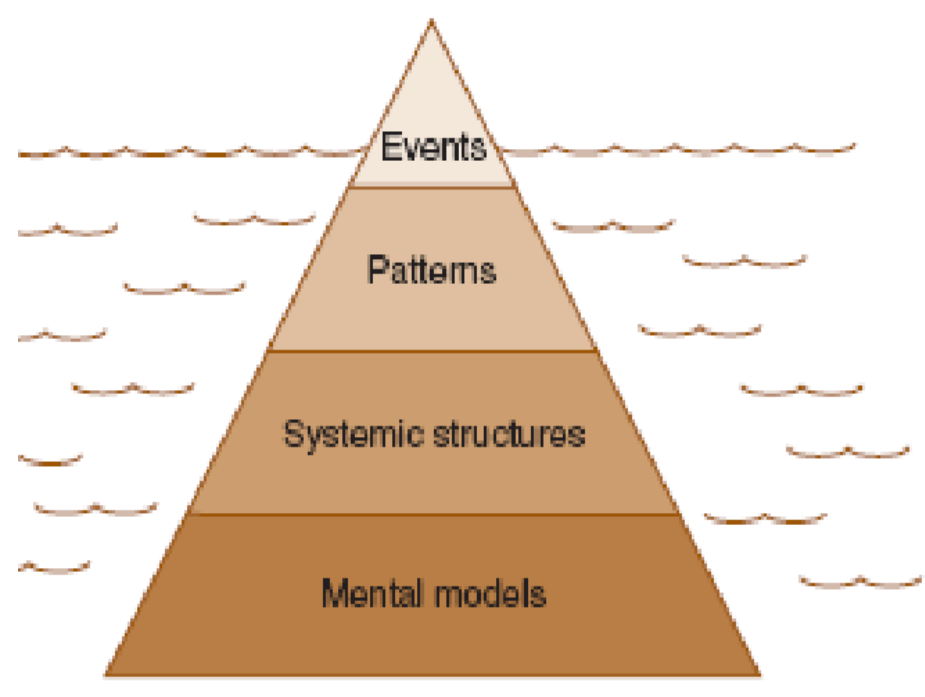

Figuur 4.3 Het ijsberg model: vier niveaus van een systeem (Maani \& Cavana, 2007).

Een belangrijk vraag is waar de leverage points - 'plekken in een complex system waar een kleine verandering in een aspect overal grote veranderingen kan bewerkstelligen' (Meadows, 2001) - van het voedselsysteem zitten. Naarmate deze leverage points zich op de diepere lagen van het systeem richten, nemen ze toe in impact en zijn ze meer transformatief op het systeem (zowel in positieve als negatieve zin). Het vinden van leverage points alleen is niet voldoende; systeemverandering vergt ook goed inzicht in de interrelaties, bijvoorbeeld via (non-lineaire) feedback loops, en hoe de gewenste uitkomst (een duurzaam voedselsysteem) kan worden bereikt met maximale synergie effecten en minimale 'trade-offs' (Kennedy et al, 2018). 
Vanwege de complexiteit en interrelaties in het agrofoodsysteem is het dus raadzaam om beleid niet alleen te richten op het aanpakken of oplossen van de negatieve uitkomsten van systemen (bijvoorbeeld biodiversiteitsverlies, stikstofuitstoot, voedselverspilling) maar ook op de onderliggende patronen die worden gedreven door maatschappelijke waarden, gedrag en beleid, die maken dat deze uitkomsten van het agrofood systeem steeds maar weer opnieuw ontstaan. Dit geeft tevens de mogelijkheid om collectief na te denken over toekomstgerichte waardenpatronen onder ons voedselsysteem, gekoppeld aan de paradigma's ervan. Een redesign van ons voedselsysteem, zoals de ambitie is van de EU Farm to Fork Strategy, vergt dus een beleid met interventies op alle niveaus van het voedselsysteem. Het vergt dat maatschappelijke opgaven in samenhang worden bekeken en beleid vanuit een integraal perspectief en met een lange termijn horizon vorm wordt gegeven.

Ook in een recent rapport van OESO wordt gesteld dat een voedselsysteem aanpak voor beleidsontwikkeling nodig is om de synergiën van beleidsinterventies te versterken en de trade-offs te managen. De komende UN Food Systems Summit in september 2021 wordt georganiseerd vanuit de insteek dat beter beleid voor voedselsystemen nodig is om voortgang op de sustainable development goals (in feite de maatschappelijke doelstellingen) te bereiken (OESD, 2021).

Een provinciebestuur heeft maar beperkt invloed op het voedselsysteem, maar kan wel experimenteerruimte bieden en ruimte geven aan initiatieven die passen in de transitie agenda (strategic niche experiments). In paragraaf 6.1 wordt ingegaan op circulaire voedselsystemen als een systeemverandering met positieve impacts op een aantal maatschappelijke opgaven, maar ook een aantal trade-offs.

\section{Transdisciplinaire aanpak}

Een opgavegerichte beleidsaanpak vergt ook dat grotere delen van de samenleving actief betrokken zijn bij het agenderen, ontwikkelen en inbedden van innovatie (Rathenau, 2020). Volgens het International Panel of Experts on Food Systems vereist duurzame voedselsystemen een transdisciplinaire aanpak (IPES-Food, 2015). Een aanpak waarbij gebruik wordt gemaakt van wetenschappelijke inzichten uit meerdere disciplines en de praktijkkennis van innovatieve ondernemers en nieuwe samenwerkingsplatforms.

Het aansturen van opgavegerichte innovatie vergt een actieve vorm van programmamanagement. Volgens het Rathenau instituut zijn elementen van zo'n programmamanagement: veranderingstheorie als basis, een brede opvatting van kennis en innovatie, een brede set van activiteiten, een brede betrokkenheid van partijen in de hele programmacyclus en een actief programmamanagement gedurende de hele programmacyclus (Rathenau, 2020).

Ook in Europa worden de maatschappelijke opgaven in het innovatiebeleid belangrijker. De Europese Commissie eist bijvoorbeeld dat deelprogramma's binnen Horizon Europe tonen hoe ze bijdragen aan de Green Deal. Ook is er aandacht voor de maatschappelijke aspecten van innovatie. In de missies van de EU staan bijvoorbeeld niet de wetenschappelijke en technologische doelen centraal, maar de maatschappelijke impact die bereikt moet worden met innovatie. Verder heeft iedere missie een mission board met burgers, bedrijven, overheden en maatschappelijke partijen. Die groepen praten vooraf én tijdens het onderzoek mee (Rathenau, 2020).

\section{Gebiedsgerichte aanpak}

In toenemende mate wordt een aantal maatschappelijke opgaven in Nederland geïntegreerd in een gebiedsgerichte aanpak. In zo'n gebiedsgerichte aanpak kunnen meerdere (transitie)agenda's worden gecombineerd, bijvoorbeeld op het gebied van stikstof- en klimaatdoelstellingen en duurzame energie, aansluitend bij de vele inspirerende voorbeelden van ondernemers en (bottom-up) duurzaamheidsinitiatieven en -coalities. Veel maatschappelijke thema's komen samen in de wijze waarop we de grond gebruiken. Zeker als het PBL advies 'functie volgt bodem' wordt gehanteerd. Mooi voorbeeld is het project 'Brabants Bodem' waarin met de betrokken partijen in een gebied wordt samengewerkt aan gezonde bodem, biodiversiteit en landschap en deze ecosysteemdiensten door de betrokken melkveehouders worden vergoed. 
Hoewel de rol en bevoegdheid van een provincie erg goed aansluit op een gebiedsgerichte aanpak, is het tegelijk wel zo dat niet alle uitdagingen van het landbouw-voedselsysteem via een gebiedsgerichte aanpak op te lossen zijn: de schaal van het huidige systeem (Noordwest Europa) is veel groter dan de provincie, en een gebiedsgerichte aanpak sluit ook niet aan op een thema als ongezonde/nietduurzame consumptie.

\section{Samenvatting}

De landbouw- en voedsel sector in Nederland is een zeer innovatieve sector met een grote bijdrage aan onze economie. Tegelijkertijd zijn onze huidige voedselconsumptie en -productiepatronen sterk gerelateerd aan een aantal urgente en mondiale duurzaamheidsopgaven op het gebied van gezondheid en welzijn van mens, dier en planeet. Deze duurzaamheidsopgaven leiden tot grote maatschappelijke kosten; deze overtreffen mondiaal de economische baten. Deze maatschappelijke kosten worden nu nog veelal betaald door anderen (belastingbetalers, andere landen, volgende generaties). Ongezonde voeding, bijvoorbeeld, leidde tot 6 miljard euro aan zorgkosten per jaar in Nederland (RIVM, 2015);

Versnelde actie en radicale veranderingen in productie en consumptie, transities, zijn vereist om verdere milieudegradatie te stoppen, internationaal afgesproken doelen te halen en tegelijk ook de economische duurzaamheid van het landbouwvoedselsysteem te verbeteren. Een redesign van het voedselsysteem is ook vastgelegd in de Farm to Fork strategy die de EU momenteel ontwikkelt. In Nederlandse kabinet positioneert maatschappelijke opgaven vooral als economische kansen voor bedrijven, o.a. in het missiegedreven Topsectorenbeleid waarin technologieontwikkeling en bedrijven centraal staan. Echter, impact op maatschappelijke opgaven vergt ook een ander type beleid. Dit beleid, gericht op transities, heeft een aantal karakteristieken:

- Het heeft een sterkere politieke lading om dat de maatschappelijke opgaven moeten worden gerealiseerd in een krachtenveld van uiteenlopende opvattingen, verwachtingen en (deel)belangen van bedrijven, onderzoekers, overheden en burgers (Rathenau, 2020).

- Het vergt een systeemaanpak waarin aandacht nodig voor de grondoorzaken van de maatschappelijke opgaven, en waar de synergiën van beleidsinterventies worden versterkt en de trade-offs worden gemanaged (OECD, 2021).

- Het vergt een transdisciplinaire aanpak waarbij gebruik wordt gemaakt van wetenschappelijke inzichten uit meerdere disciplines en de praktijkkennis van innovatieve ondernemers en nieuwe samenwerkingsplatforms (IPES Food, 2015)

In toenemende mate wordt een aantal maatschappelijke opgaven in Nederland geïntegreerd in een gebiedsgerichte aanpak. In zo'n gebiedsgerichte aanpak kunnen meerdere (transitie)agenda's worden gecombineerd, bijvoorbeeld op het gebied van stikstof- en klimaatdoelstellingen en duurzame energie, aansluitend bij de vele inspirerende voorbeelden van ondernemers en (bottom-up)

duurzaamheidsinitiatieven en -coalities.

Gezien de omvang van de opgaven en de schaal waarop het landbouwvoedselsysteem is georganiseerd, is het wenselijk dat de provincie de samenwerking versterkt met andere regio's om transities te bevorderen. De provincie Noord-Brabant heeft in zo'n samenwerking veel te bieden, zoals een aantal grote ketenspelers, innovatieve ondernemers, samenwerkingsverbanden (bijv Agrofood Capital), proeftuinen (bijv Agroproeftuin de Peel) en kennispartijen. Tegelijk kan aansluiting gezocht worden bij o.a. Food Valley (Gelderland), Mineral Valley (Overijssel), Boerderij van de Toekomst (Flevoland), etc. 


\section{$5 \quad$ Trends en ontwikkelingen}

In dit hoofdstuk worden ontwikkelingen in het voedselsysteem van Noordwest Europa, Nederland en Noord-Brabant beschreven. Het hoofdstuk volgt dezelfde structuur (het voedselsysteem) als hoofdstuk 3 , met dit verschil dat voedselsysteem resultaten niet worden beschreven. Dat zou te speculatief worden.

\subsection{Voedselsysteem activiteiten}

\subsubsection{De keten van productie en consumptie}

In de afgelopen decennia is er een sterke verschuiving geweest met betrekking tot relaties in de gehele voedselketen. Van een door de producent aangedreven keten, waar de producent bepaalt wat er geproduceerd wordt en tegen welke prijs, naar een consument gedreven keten waarin met name de grote supermarkt ketens grote invloed hebben op de productie en de prijs (WRR, 2014). De

Nederlandse retail voor voedsel en overige "kruidenierswaren" groeide in 2018 nog met $3.2 \%$ tot een omzet van 65 miljard Dollar (Marketline, 2020). De verwachting is dat deze groei zich in het komend decennium zal voortzetten. Er wordt verwacht dat de Nederlandse retail in 2023 een omzet bereikt zal hebben van 75 miljard Dollar, een groei van 13.9 \% t.o.v. 2018 (Marketline, 2020). Deze groei komt voort uit een inkomensgroei van consumenten. De kwaliteitseisen en de contractvormen worden beïnvloed door de retail en er ontstaan nieuwe verdienmodellen, omdat ook de gegevens over de productiewijze aan het product gekoppeld worden (WRR, 2014).

Hoewel er ook in Nederland een tendens lijkt tot het kopen van meer lokale producten (bijvoorbeeld via \#supportyourlocals), mede in de huidige Corona-tijden, en het ontwikkelen van korte ketens tussen producenten en consumenten, zal een aanzienlijk deel van de voedselvraag worden beantwoord door internationale handel en transport. De huidige situatie van het agrofood systeem, zoals deze is geschetst in een voorgaand hoofdstuk zal daarom zonder interventies niet wezenlijk veranderen. Deels komen de producten uit Noordwest Europa, deels van daarbuiten.

In 2017 hebben bijna 1.100 agrarische ondernemers in Noord-Brabant (een deel van hun) afzet via een korte keten geleverd. Hierbij is de volgende definitie van een korte keten gehanteerd: nul of max 1 schakel tussen producent en consument. In 2020 is dit aantal toegenomen tot 1.375, oftewel 14,7\% van de agrarische ondernemers (Venema et al, 2021, Wageningen Economic Research, nog te publiceren).

\subsubsection{Landbouw}

\section{Bedrijfsontwikkeling}

Landbouw is in veel gebieden nog de belangrijkste gebruiker van de grond en de provincie wil ruimte blijven bieden voor landbouwactiviteiten. De landbouw en de aanverwante industrie, zowel in de aanlevering van inputs als de verwerking van producten blijven een belangrijke positie houden. Het aantal landbouwbedrijven is in de afgelopen jaren sterk afgenomen, met name in de glastuinbouw en de varkenshouderij. Het productievolume is evenwel nagenoeg gelijk gebleven (Venema et al., 2019). $\mathrm{Er}$ is dus sprake van een sterke schaalvergroting van bedrijven, en de verwachting is dat deze schaalvergroting door zal gaan om de kostprijs te. Dat kan gebeuren door fysieke vergroting van bedrijven, meer land, meer dieren. Maar het kan ook door vergroting van de financiële omzet op dezelfde oppervlakte, een intensivering van het landgebruik of een omzetting naar hoger salderende teelten.

Naast de hoofdtrends van schaalvergroting en specialisatie is te zien dat een toenemend aantal bedrijven op zoek is naar een andere strategie, gericht op het scheppen van meerwaarde of het vervullen van andere (betaalde) functies. Het gaat dan om korte ketens (Herenboeren), 
natuurinclusief werken (beheersovereenkomsten, samenwerking natuurorganisaties e.d.), waterberging, zorg, recreatie. Veel van deze functies zijn niches, waar voor een beperkt aantal bedrijven een (goede) boterham te verdienen is. Economisch kan de betekenis beperkt zijn, maar voor de verbinding tussen boer en burger en de kwaliteit van de leefomgeving zijn ze wel belangrijk.

De sectoren die zich richten op groenten en op non-food producten (boom-, bollen- en bloementeelt) zullen een forse meerwaarde weten te scheppen en zullen sterk blijven (Venema et al., 2019). De toeleverende en verwerkende industrie zal een belangrijke meerwaarde blijven scheppen uit de landbouwproductie van Brabant.

De internationale oriëntatie, bestaande uit export en import van producten zal niet op korte termijn veranderen. Nederland, en zeker Brabant, kan niet zelfvoorzienend worden voor haar gehele voedselpakket (zie hoofdstuk 6 voor verdere uitwerking). Berekeningen laten zien dat zelfs bij volledige sturing van de landbouwproductie, slechts 30 tot $40 \%$ van het voedsel in de provincie zelf geproduceerd kan worden.

Door de afname van het aantal landbouwbedrijven zullen er bedrijfsgebouwen vrijkomen. De verwachting is dat dit het sterkst is in het oostelijk deel van de provincie (Figuur 5.1).
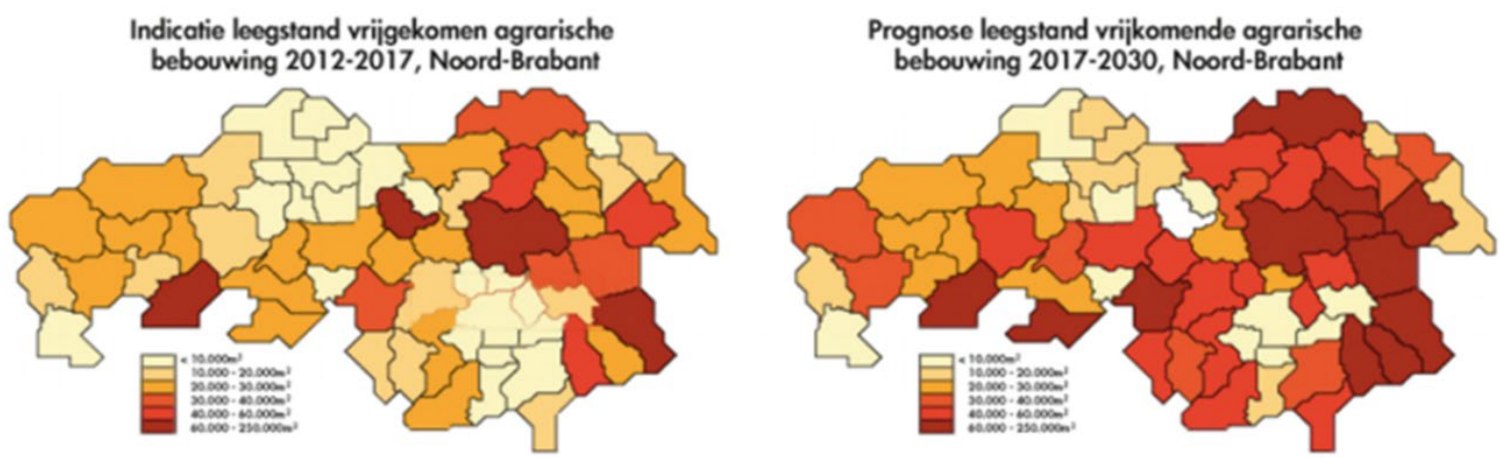

Figuur 5.1 Links: vrijgekomen agrarisch vastgoed (excl. glas) in 2012-2017 per gemeente in NoordBrabant. Rechts: prognose vrijkomend agrarisch vastgoed (excl glas) in 2017-2030 per gemeente (maximum variant (zonder opvolger/onbekend). Bron: Gies, 2019, Wageningen Environmental Research.

\section{Veehouderij}

In de context van Noordwest Europa is Noord-Brabant een belangrijk gebied voor de intensieve veehouderij, met name varkens. Een groot deel van de productie wordt geëxporteerd naar landen binnen de Europese Unie. De veehouderij levert een belangrijke bijdrage aan de economie. Aan de andere kant is de ontwikkeling van de veehouderij wel aan grenzen gebonden vanwege de effecten op milieu, volksgezondheid en omgevingskwaliteit (geur) in een zeer dichtbevolkte regio.

De opkoopregeling van de varkenshouderij zal mogelijk leiden tot enige verlichting van de emissies naar de lucht. Voor het grondgebruik zal dit weinig betekenis hebben, aangezien het meestal om grondloze bedrijven gaat. Daarnaast is het de vraag in hoeverre het de concentratie van de veehouderij zal verminderen. De concentratie van veehouderij wordt sterk bepaald door macroeconomische factoren en de technische en institutionele infrastructuur (de Wolf et al., 2019). Tegelijk is de efficiëntie van de gehele infrastructuur rond de sector sterk afhankelijk van de omvang van de primaire productie, en kan een krimp van de veehouderij grote gevolgen hebben voor toeleveranciers en afnemers.

\section{Plantaardige productie}

Door de schaarste aan grond voor diversie functies (wonen, bedrijvigheid, natuur en recreatie), is de verwachting dat landbouwgrond duur zal blijven. De landbouwgrond is de enige grond die relatief goedkoop is ten opzichte van andere functies en die eenvoudig van functie kan veranderen. In feite functioneert het als planologische reserveruimte.

Deze grond is dan te duur voor bulkproductie, zoals de teelt van granen en suikerbieten als grondstof voor een biobased chemische industrie. Er zullen vooral hoog salderende teelten blijven en deze zullen mogelijk uitbreiden: boomteelt, sierplanten en groenten. Een aantal van deze teelten kenmerken zich 
wel door een intensief grondgebruik en hogere inzet van van gewasbeschermingsmiddelen. Hoewel de alarmerende berichten over de achteruitgaande bodemkwaliteit worden gerelativeerd, blijft het wel belangrijk om aandacht te houden voor de bodemgezondheid en voor het tegengaan en opheffen van bodemverdichting (Ros, 2020).

In een aantal gevallen zullen teelten "uit de grond" komen, zoals dat gebeurd is met aardbeien waar de vollegrondsteelt deels is verschoven naar stellingenteelt en ook naar de glastuinbouw. Ook bladgroenten zoals kropsla zijn gaandeweg verschoven van vollegrondsteelt naar glastuinbouw. Dit kan mogelijk ook voor andere gewassen plaatsvinden, met name groentegewassen. Het vraagt wel grote investeringen, die dan vaak wel weer gecompenseerd worden door een forse verhoging van de productie per oppervlakte-eenheid. Het heeft ook een behoorlijke invloed op het landschap als (overkapte) stellingen en kassen worden gebouwd.

Een andere vorm van grondgebruik die een hoog saldo geeft is de plaatsing van zonnepanelen. Het is planologisch, logistiek en organisatorisch veel eenvoudiger dan het plaatsen van panelen op daken van gebouwen en huizen. Voor de grondgebruiker die erover denkt om te stoppen is het een aantrekkelijke optie. De uitvoering van de energietransitie ligt bij de gemeenten. Ontwikkelaars van zonneparken laten zich leiden door ruimtelijk beleid van provincie en gemeente en aansluitmogelijkheden op het elektriciteitsnet (de Zee et al., 2019). Het kan leiden tot de situatie dat landbouwkundig goede gronden niet meer beteeld worden, terwijl onproductieve gronden (zeer droogtegevoelige gronden bijvoorbeeld) in landbouwkundig gebruik blijven. Er kunnen positieve effecten zijn op biodiversiteit (De Zee et al., 2019) en waterbalans (meer grondwatervoeding; De Zee, persoonlijke mededeling). Ook is multifunctioneel gebruik met landbouw nog mogelijk. Door biodiversiteit, waterbalans en multifunctioneel landgebruik als criteria te gebruiken bij de planning van zonneweides, kan meerwaarde worden geschapen ten opzichte van de huidige praktijk.

Een nieuwe ontwikkeling is de teelt van gewassen in stroken, waardoor de verspreiding van plantenziekten en plagen beperkt kan worden en ook de weerbaarheid en biodiversiteit kan worden versterkt. Deze ontwikkeling heeft gevolgen voor de registratie van het landgebruik. Hoewel dat een nationaal vraagstuk is, vergt de ontwikkeling van deze teeltwijze nog innovaties op het gebied van mechanisatie. De ontwikkeling naar een toenemende efficiëntie van inputs (water, mineralen, gewasbescherming) in de plantaardige productie zet door: precisielandbouw zal een grote rol gaan spelen (Kempenaar et al., 2019). Dat zal vooral gelden voor het gebruik van gewasbeschermingsmiddelen en in iets mindere mate voor bemesting. De variabiliteit in werkingscoëfficiënten van mineralen in organische mest maken een precieze sturing van de (bij)bemesting lastig, evenals de sterk weersafhankelijke groei en nutriëntenopname door gewassen. Een mooi voorbeeld van Smart Farming in de plantaardige sectoren is het Praktijkcentrum voor Precisielandbouw in Reusel.

Ook in de veehouderij is smart farming in ontwikkeling. Met name de automatisering in de stal is ver gevorderd, zeker in de intensieve veehouderij. De monitoring van individuele dieren, een geautomatiseerd voedersysteem en voer- en melkrobots zijn inmiddels vrij gebruikelijk. Deze ontwikkelingen dragen ook bij aan de verdere verhoging van de efficiëntie van de veehouderij. Tegelijk is het wel een aandachtspunt dat de verhoging van de efficiëntie weliswaar kan leiden tot lage emissies per kg product, maar tot hogere emissies per hectare. Daarnaast staat een volledig gesloten, geautomatiseerd veehouderijsysteem in toenemende mate haaks op het maatschappelijke wensbeeld van een veehouderij waarin dieren hun natuurlijke gedrag kunnen vertonen.

Een parallelle ontwikkeling aan precisielandbouw is die van urban farming en vertical agriculture: met kunstmatig licht en in spaarzame groene gebieden van de steden kunnen landbouwproducten worden geteeld. Deze beide vormen zullen een aanvulling zijn op de diversificatie die optreedt. Ze zullen zich vooral richten op producten met een (zeer) hoge toegevoegde waarde en kleine volumes.

Samenvatting voedselsysteemactiviteiten

Het gehele systeem van voedselproductie met de ketenpartijen die grondstoffen leveren en producten afnemen en de internationale oriëntatie zal in de toekomst blijven bestaan, mits de omvang van de primaire sector niet drastisch afneemt, bijvoorbeeld als gevolg van milieumaatregelen of ruimtelijk beleid.

Het aantal landbouwbedrijven zal nog afnemen door verdere schaalvergroting, en mogelijk ook onder druk van landelijk beleid (mestwetgeving, stikstofbeleid), waarbij veel bedrijfsgebouwen vrijkomen. 
Schaalvergroting (op economische schaal, dat kan in hectares, dieren, maar ook in omzet bij gelijke grootte) is de dominante trend om kosten te besparen. Druk op de sector leidt tot versnelde schaalvergroting (kleine bedrijven stoppen, grote bedrijven worden nog groter). Technologie zal een steeds grotere rol gaan spelen in de landbouw. Een deel van de bedrijven zal zich richten op het creëren van een grotere meerwaarde binnen de huidige bedrijfsgrootte via niches als biologische landbouw, korte ketens en nevenactiviteiten in bijvoorbeeld zorg of recreatie. In 2020 is dit aantal agrarische ondernemers in Brabant dat (een deel van) hun afzet via een korte keten (max 1 schakel tussen producent en consument) toegenomen tot 1.375 , oftewel $14,7 \%$ van de agrarische ondernemers (Venema et al, 2021, Wageningen Economic Research, nog te publiceren).

Energieproductie op land zal voor een deel ook op landbouwgrond gerealiseerd worden, de regie daarop ontbreekt grotendeels.

De hoge grondprijzen zullen een stimulans blijven om de grond (zeer) intensief te gebruiken voor hoog salderende teelten die voor een deel in de non-food sector zitten. Er is waarschijnlijk weinig ruimte voor de teelt van bulkproducten. De economie van de primaire productie blijft een sterk sturende factor in het landgebruik.

\subsection{Sociaaleconomische factoren}

\subsubsection{De vraag naar grond}

De landbouw in Noord-Brabant is erg divers en is vaak erg concurrentiekrachtig. De sector is daarom nog steeds bereid en bij machte om relatief hoge grondprijzen te betalen. De omgevingsvisie van de provincie heeft als belangrijkste uitdaging om de stedelijke agglomeraties te versterken, in combinatie met een verbetering van de groene omgeving. Op dit moment is het areaal aan natuur- en recreatieterreinen 100000 hectare. Het doel van de provincie om natuurgebieden te beschermen en te versterken, door onder meer $1500 \mathrm{~km}$ aan ecologische verbindingen te creëren, waarvan 700 nog moet worden gerealiseerd. De totale oppervlakte aan natuur gebieden moet groeien tot 129000 hectare in 2027. Zo'n 10\% daarvan moet worden gevormd door landbouwgrond in natuur om te zetten, o.a via het Groen Ontwikkelfonds Brabant. Zie ook figuur 3.14 in paragraaf 3.3.2.

Tegelijk is er behoefte aan meer grond voor woningbouw en bedrijven terreinen. Volgens Brabant.nl gaat de verstedelijking door in de komende jaren, zal de bevolking beperkt groeien en het aantal personen per woning nog licht dalen. De bevolkingsprognose geeft aan dat er nog ruim 155000 huishoudens bijkomen tussen 2020 en 2040. Dat zal voor een aanzienlijk deel bestaan uit oudere alleenstaanden $(75+)$. Dat is een toename van $13.4 \%$. De groei van de woningvoorraad wordt geschat op ruim $16 \%$. Als dat laatste percentage wordt toegepast op het areaal voor woningen van 60000 hectare in Noord Brabant is de extra behoefte aan bouwgrond ruim 9600 hectare (https://bevolkingsprognose.brabant.nl/hoofdstuk/ontwikkeling-van-de-brabantse-woningvoorraad).

Voor de bedrijventerreinen wordt tussen 2018 en 2030 een groei van $7 \%$ verwacht, hetgeen neerkomt op 900 hectare (https://www.brabant.nl/onderwerpen/ruimtelijkeontwikkeling/werklocaties/prognoses-werklocaties). Dat betekent dat een extrapolatie naar het jaar 2040 neerkomt op ongeveer 1700 hectare. De STEC-groep (de Kort et al., 2018) schat in dat er voldoende oppervlakte is aan kantoren en dat er geen aanvullende behoefte is tot 2030.

De totale ruimtebehoefte voor al deze functies samen bedraagt ruim 40000 hectare $(29000+9600+$ 1700). Dat komt neer op een kleine 2000 hectare per jaar. Dat getal komt overeen met de waarde die wordt gebruikt door Venema et al. (2019) en is afgeleid van de gegevens van het CBS. De Barometer Duurzame landbouw (Venema et al., 2019) geeft een totale oppervlakte van 232000 hectare landbouwgrond in 2019.

De verwachting is dat het areaal landbouwgrond eveneens zal dalen als gevolg van toenemende vochttekorten door klimaatverandering. Dat zal met name gebeuren op de meest droogtegevoelige gronden. Of deze gronden daadwerkelijk buiten gebruik zullen raken, of dat ze extreem lage opbrengsten hebben is lastig te voorspellen. Daarnaast is er sprake van een toenemende competitie om land voor met name zonnepanelen. Deze hebben een hoge financiële opbrengst per hectare en 
kunnen snel en eenvoudig bijdragen aan de realisatie van gemeentelijke doelstellingen voor de energietransitie. De klimaatdoelen op de lange termijn kunnen ook leiden tot een versterkte aanplant van bos, hetzij als aaneengesloten arealen, hetzij deels als agroforestry. Voor zonneweides en bos is het lastig om een areaal te noemen.

Vanwege de vraag naar grond voor o.a. woningen en duurzame energie (bijv zonnepanelen), de uitvoering van het natuurnetwerk Brabant en de bossenstrategie t.b.v. klimaatdoelstellingen zal het landbouwareaal afnemen. De productiviteit van het landbouwareaal staat onder druk door klimaatverandering, leidend tot toenemende droogte met name op de hoge zandgronden in Brabant. Dit kan leiden tot verdere afnamen van grond voor landbouwfuncties; inschatting van arealen zijn lastig te maken.

\subsubsection{Marktontwikkelingen}

Nederland is een belangrijk exportland en ontwikkelingen op de internationale markt zijn daarom erg belangrijk. Volgens Marketline (2020) wordt veel energie geïnvesteerd in internationale relaties en heeft dit bijgedragen aan het versterken van de exportpositie.

Het is echter heel lastig om toekomstige ontwikkelingen te schetsen in dit korte bestek. Bovendien zijn ontwikkelingen vaak onzeker. Hoewel er een groeiende aandacht is voor het kopen van lokale producten of het betrekken van grondstoffen zo dicht mogelijk bij "huis", zal er altijd sprake zijn van internationale handel, vooral binnen de Europese Unie, maar zeker ook daarbuiten. De mate waarin Nederland zich onafhankelijk kan opstellen als het gaat om voedselvoorziening komt later aan de orde.

De Europese Unie probeert sinds 2008 het bestuur meer open en transparant te maken. Nederland doet mee aan dat proces. In de "Open Government Index 209", een onderdeel van het World Justice Project, scoort Nederland vijfde van de in totaal 102 gerangschikte landen. Ook in zakelijke activiteiten die betrekking hebben op voedsel wordt gewerkt aan meer openheid en transparantie. Dat heeft geleid tot een organisationele infrastructuur die zorgt dat alle actoren in de voedselketen waarmee partijen meer kunnen tonen over de productiewijze, herkomst en veiligheid (Marketline, 2020). Dat is vooral van belang voor internationale waardeketens waarbij producenten en consumenten met elkaar worden verbonden (Delanay et al., 2018).

\subsubsection{Internationale verbindingen}

De provincie Noord-Brabant heeft zich ontwikkeld tot een sterk geïndustrialiseerd en internationaal georiënteerde regio. Dat heeft geleid tot een sterke intensivering van het gebruik van de regio: sterke verstedelijking, een sterk vervoersnetwerk en een watersysteem dat zowel verstedelijking als landbouw kan bedienen. Ook het gebruik van de niet bebouwde ruimte is intensiever geworden, zowel via landbouw als (dag)recreatie (PNB, 2014).

De kenniseconomie in Noord-Brabant groeit sterk, er vond en vindt een verschuiving plaats van de arbeidsintensieve maakindustrie naar de kennisintensieve diensten. Het aandeel hoger opgeleide mensen in de bevolking groeit en het belang van de verbinding tussen kennisinstellingen is groot. De provincie ziet het als haar taak om Noord-Brabant verder te ontwikkelen als een duurzame kennisgeoriënteerde regio die op Europees niveau kan concurreren met een diversiteit aan economische clusters.

De nabijheid van de Randstad, de Vlaamse Ruit en het Ruhrgebied zijn er veel kansen voor economische ontwikkeling die al worden benut. De centrale ligging ten opzichte van stedelijke agglomeraties is een sterk punt. Zowel de interne als de externe toegankelijkheid van de provincie is een knelpunt. De behoefte aan goede connecties met het achterland in België en Duitsland groeit. De provincie Noord-Brabant zet in op verbetering van de toegankelijkheid via wegen, spoorlijnen en vliegverbindingen. Men ziet nog een mogelijkheid in de groei in de mobiliteit in de provincie met $40 \%$ in de periode tot 2030. Het gebruik van motorvoertuigen is in de laatste 10 jaar met $25 \%$ gestegen en de verwachting is dat die groei zich doorzet. De effecten van de coronacrisis (o.a. meer thuiswerken) zijn daarbij niet meegenomen. Dat betekent dat de behoefte aan grond voor andere functies dan landbouw groter is dan in bovenstaande rekensom is opgenomen. 


\subsubsection{Consumenten ontwikkelingen}

Deze paragraaf geeft inzicht in de ontwikkelingen van consument voorkeuren en keuzes van producten. Sommige ontwikkelingen zijn zekerder dan andere.

\section{Vergrijzing}

Het aandeel van de bevolking dat ouder is dan 65 jaar ten opzichte van de "productieve" bevolking wordt omschreven als de "grijze druk", terwijl de "groene druk" wordt gedefinieerd als het aandeel van de bevolking in de leeftijd van 0 tot en met 19 jaar ten opzichte van de productieve bevolking. Het zijn beide maten die aangeven hoeveel mensen er zijn buiten het actieve arbeidsproces per persoon in de leeftijd dat ze actief zijn in het arbeidsproces. Figuur 5.2 laat zien dat de groene druk constant blijft in de komende periode, maar dat de grijze druk, het aandeel ouderen sterk zal toenemen; de prognose is dat in 2040 40\% van de populatie onder de 20 jaar is en $54 \%$ ouder dan 65 jaar (https://brabant.databank.nl/kiosken/index.html).
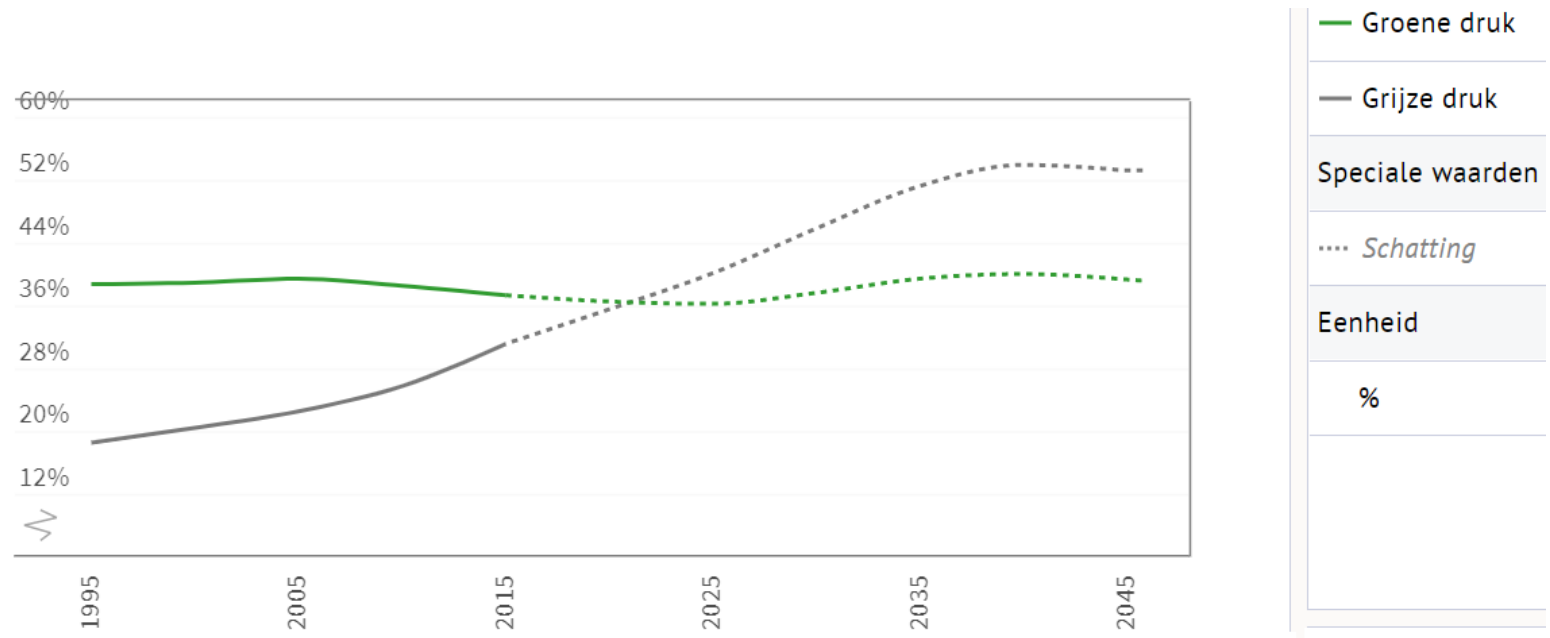

Figuur 5.2 Het aandeel van de bevolking ouder dan 65 jaar (grijze druk) en jonger dan 20 jaar (groene druk) ten opzichte van de bevolking in de "productieve" leeftijdsgroepen Bron: https://brabant.databank.nl/kiosken/index.html (geraadpleegd 11-2-2021).

\section{Bevolkingsgroei}

Figuur 5.3 beschrijft het demografisch transitiemodel, de fasen waarin een bevolking zich kan bevinden en wat dat betekent voor de groei van een bevolking. Noordwest Europa, en ook NoordBrabant komen in 2040 terecht in fase 4 van de demografische ontwikkeling, waarbij de bevolkingsgroei afneemt en tot stilstand komt. Uiteindelijk zal er sprake zijn van een krimpende bevolking. Toch laat Figuur 5.4 een groeiende bevolking zien. Dat is een gevolg van een lichte groei in de periode tot 2030 en voor $70 \%$ wordt de toename verklaard door migratie. 


\section{The demographic transition in 5 stages $\quad$ OurWorc The demographic transition in 5 stages}

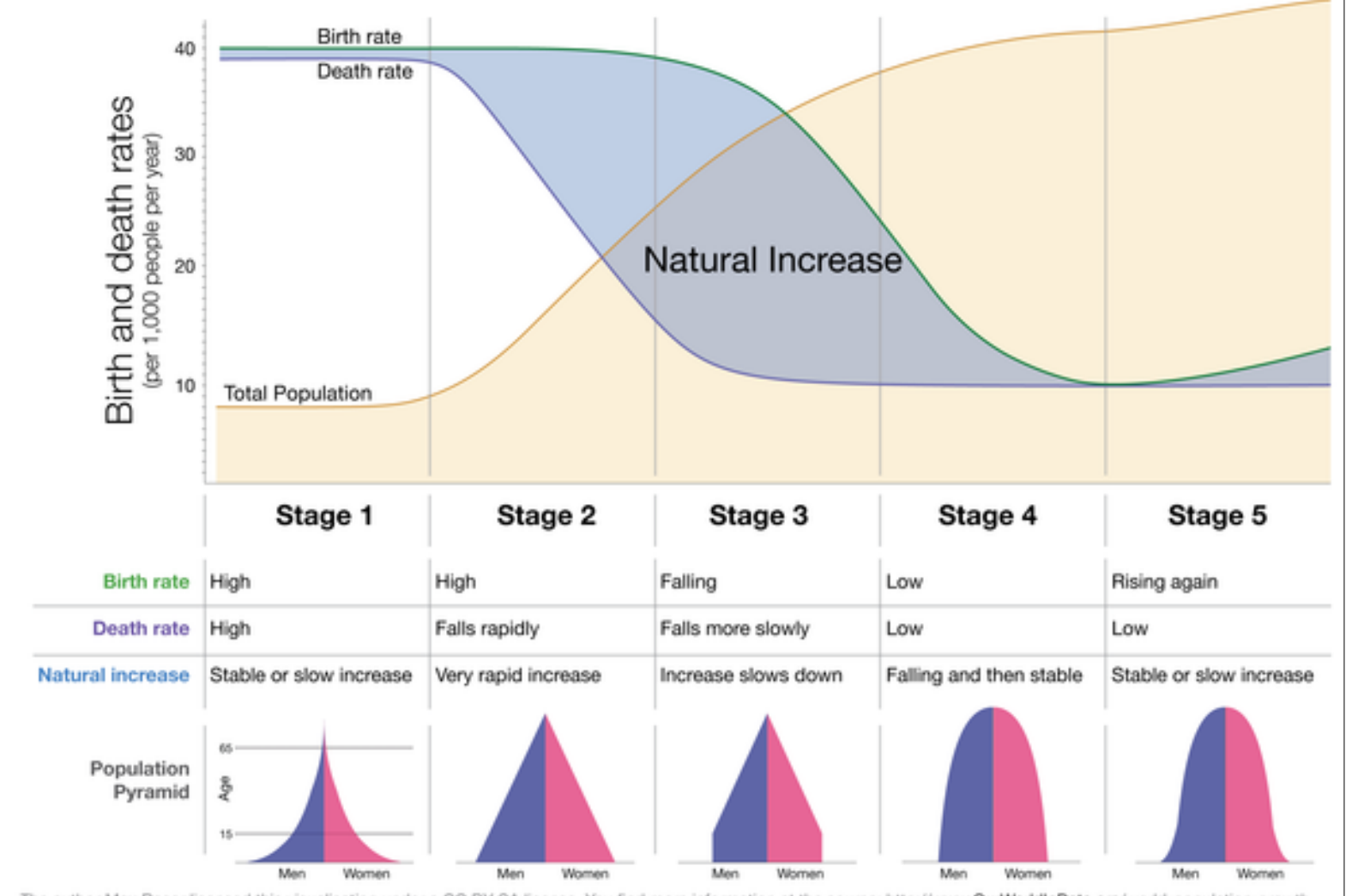

Figuur 5.3 Demografisch transitiemodel. Bron: Our World in Data.

Ontwikkeling aantal inwoners

\begin{tabular}{|l|r|r|}
\hline & Bevolking & Prognoses - Bevolking - totaal \\
\hline 2000 & 2.356 .005 & \\
\hline 2019 & 2.544 .805 & 2.537 .095 \\
\hline 2040 & & 2.646 .110 \\
& $<2.400 .000$ \\
& $2.400 .000<2.460 .000$ \\
& $2.460 .000<2.520 .000$ \\
& & $2.520 .000<2.580 .000$ \\
& $>=2.580 .000$ \\
\hline & & Provincie Noord-Brabant - Prognoses 2017 \\
\hline Speciale waarden: & Prognose/voorlopige cijfers \\
Eenheid: & personen \\
Bron: &
\end{tabular}

Figuur 5.4 Bevolkingsontwikkeling in aantallen in de provincie Noord-Brabant. Bron: Provincie Noord-Brabant - Prognoses 2017. 


\section{Verstedelijking}

De verwachting is dat de stedelijke bevolking in 2040 met $20 \%$ is toegenomen ten opzichte van nu (2020). Deze nationale verwachting geldt ook voor Noord-Brabant. De bevolking is grotendeels woonachtig in stedelijke netwerken met meerdere kernen dicht bij elkaar. De verwachting is dat de steden Breda, Tilburg en Eindhoven zullen groeien en de anderen gelijk blijven of zelfs krimpen. Het aantal personen per huishouden zal in deze periode ook verder afnemen (bron: Provincie NoordBrabant - Prognoses 2017).

\section{Veranderende voedingspatronen en voorkeuren}

Als gevolg van veranderende gewoonten (lifestyle), toenemende verstedelijking en een toenemende voorkeur voor "grazen" of "snacken" tijdens het forenzen, worden traditionele maaltijden steeds meer vervangen door snacks (IRI, 2018). Het aanbod van zowel gezonde als ongezonde snacks neemt toe en er zijn diverse mogelijkheden om deze onderweg te kopen. Verpakt voedsel (verwerkt eten en drinken) is nu goed voor de helft van de consumentenbestedingen in de geïndustrialiseerde landen (Gehlhar and Regmi 2005: 6). Verpakte producten bieden meer mogelijkheden tot productdifferentiatie en koppeling aan productmerken. De marketing is daarom steeds belangrijker geworden voor alle voedselproducten. Naast de trend van gemaksvoedsel, wat vaak wordt geassocieerd met ongezond, is er ook een groeiende belangstelling voor gezond voedsel en gezonde voeding (Kang et al., 2015). In het algemeen zijn consumenten meer fruit en groente en minder suiker, zout en vet gaan eten (Agrimatie, 2017). Door voedingsgerelateerde ziekten zoals obesitas, krijgen Nederlandse consumenten meer belangstelling voor gezond eten, speciaal als ze uit eten gaan (Jones, 2009). Consumenten kiezen gezondere maaltijden, kleinere porties en hebben een groeiende voorkeur voor restaurants die deze mogelijkheden bieden (Kang et al., 2015). Aan de andere kant dient te worden vermeld dat deze trend betrekking heeft op een relatief beperkte groep consumenten en is het gerelateerd aan de sociaaleconomische positie (Lalluka et al., 2006). Mensen in een hogere sociaaleconomische positie hebben sterkere voorkeuren voor gezonde voeding dan mensen in lagere sociaaleconomische posities. De toenemende welvaart in Nederland heeft in de afgelopen decennia geleid tot een toename van de consumptie van voedsel, uitgedrukt in calorieën per persoon en tot een verandering van de samenstelling van het dieet.

Overeenkomst de wet van Bennett (Bennet, 1941) zorgt een verandering in inkomen tot een sterke verandering in de vraag naar voedsel. Er worden minder zetmeelrijke bulkproducten en peulvruchten gegeten ten gunste van vet, suiker en dierlijke producten (CEPII, 2017). Met andere woorden, mensen met hogere inkomens hebben een hogere inname van energie en consumeren meer zoetigheid, groenten en fruit, oliën en vetten, vlees en vis, zuivel en eieren en minder zetmeelrijke groentes zoals peulvruchten (Figuur 5.5). Andere belangrijke sturende krachten zijn de mondialisering en de verstedelijking. Immers, gewassen die alleen lokaal verbouwd worden en moeilijk zijn op te slaan of te transporteren, zoals wortels en knollen, zullen minder worden geconsumeerd door een stedelijke en vaak meer welvarende bevolking dan aardappelen die die eenvoudig vervoerd en verwerkt kunnen worden tot allerlei producten. Een vergelijkbare trend is te zien bij een verschuiving van granen zoals millet en sorghum welke minder populair zijn bij welvarende huishoudens dan rijst en tarwe (CEPII, 2017). 


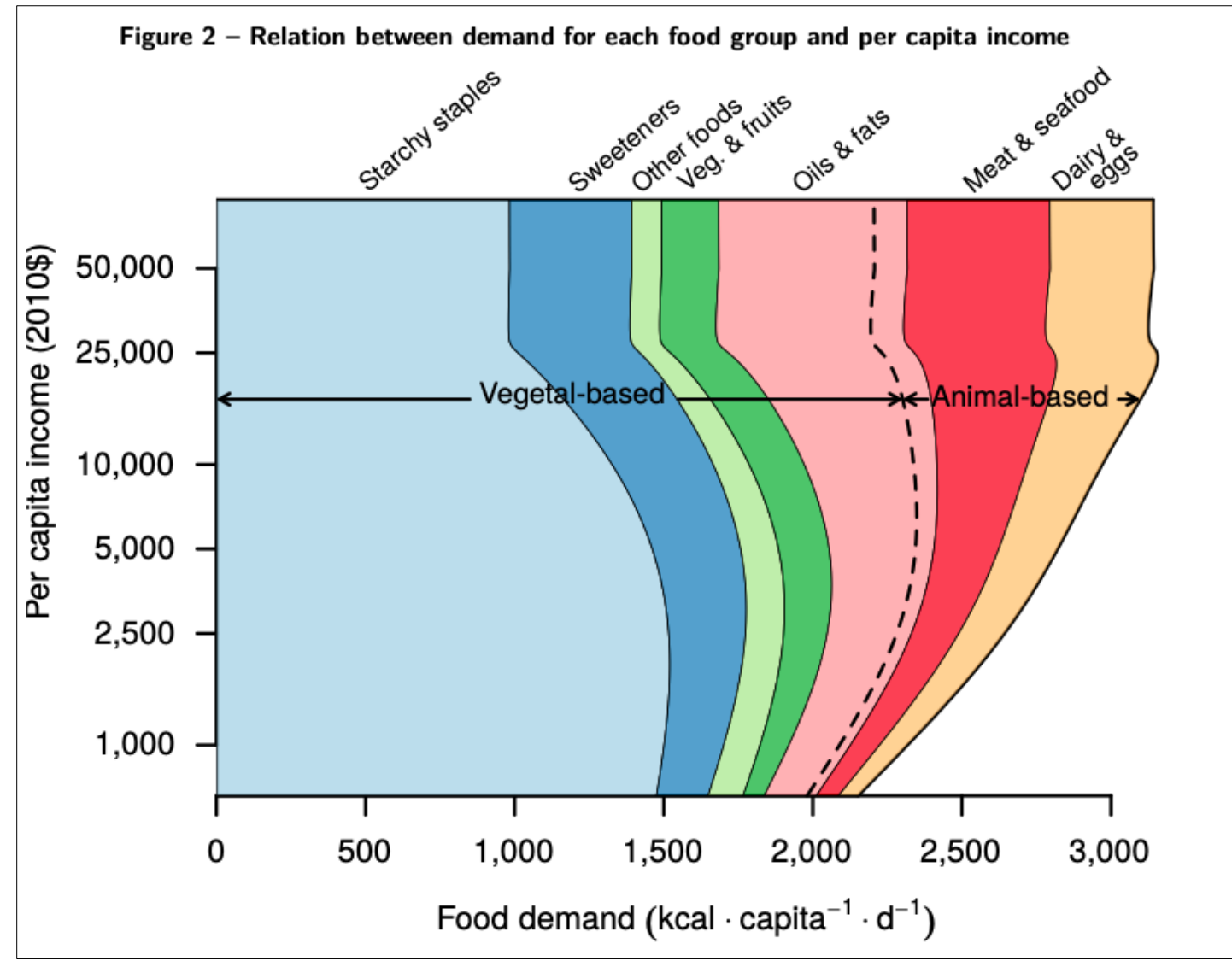

Figuur 5.5 De relatie tussen vraag naar voedselproducten en het inkomen per hoofd van de bevolking (CEPII, 2017).

\section{Een groeiende behoefte aan transparante ketens}

Goede en gedetailleerde informatie over de gehele productieketen is voor Nederlandse consumenten belangrijk. Dat geldt zowel voor millennials als voor de oudere generaties. Zij zien allemaal het belang van de herkomst en productiewijze van hun voedsel. Voedselschandalen, in combinatie met de opkomst van meer internationale merken, meer verwerkte producten en langere verticale ketens zorgen voor een toenemend bewustzijn van het belang van transparante ketens.

\section{Lokaal kopen}

Op basis van marktonderzoek van IRI (2018) is het kopen van lokaal geproduceerd voedsel steeds populairder aan het worden. Iets minder dan de helft van de Nederlandse consumenten (46\%) vindt het belangrijk om ethische overwegingen mee te nemen bij het kopen van producten en hebben een voorkeur voor lokaal geproduceerd voedsel. $36 \%$ van de Nederlandse consumenten is bereid om meer te betalen voor duurzaam geproduceerd voedsel (GFK, 2018).

In 2019 besteedden Nederlandse consumenten 18\% meer aan voedsel met een duurzaamheidskeurmerk dan het jaar ervoor. Het marktaandeel van bestedingen aan duurzaam voedsel in de totale bestedingen aan voedsel is toegenomen van 12\% naar 14\% (Logatcheva, 2020). Hoewel dit aandeel nog beperkt is, er is wel een duidelijke behoefte aan meer lokale producten waarvan de productiewijze bekend is. Jongere consumenten (18 - 24 jaar) doen het vooral vanwege de betere smaak en kwaliteit dan industriële producten, een betere verhouding tussen prijs en kwaliteit is belangrijk voor de groep van 25 - 34 jaar, terwijl consumenten boven de 35 vooral de ondersteuning van lokale producenten belangrijker vinden. Een andere motivatie voor deze consumenten is het vermijden van supermarkten (Martinez et al., 2010). De hogere prijs voor lokale producten is vaak wel een barrière voor consumenten.

\section{Beleving en waardering van voedsel}

Sinds 1995 wordt onderzoek gedaan naar de symbolische waarde van uit eten gaan en de verbonden sociale patronen (Warde \& Martens, 2000). Voedsel is in feite geen primaire behoefte meer en is meer omgevormd tot een vorm van entertainment en een manier om status, smaak en onderscheid met anderen te tonen. Door de toenemende welvaart besteden Nederlandse consumenten gemiddeld meer 
geld aan uit eten gaan, wat leidde tot een groei van de sector met $1.5 \%$ (ING \& Geijer, 2020). Dit was uiteraard voor de Corona-crisis. Vooral de stijging van lonen en verlaging van de belastingen hebben de bestedingen in cafés en restaurants gestimuleerd. Uit eten gaan is steeds meer een beleving geworden door steeds meer speciale restaurants en de gerechten en diensten die ze aanbieden. Individualisering is een belangrijke drijfveer voor de speciale beleving van de consument. Trends zijn lokaal geproduceerd voedsel, innovaties in gerechten, vegetarische gerechten en ambachtelijke gebrouwen bieren. De behoefte aan authenticiteit en een groeiend bewustzijn verklaren de groeiende consumptie van producten die regionaal, echt en uniek zijn (Doomen et al., 2019)

De maatschappelijke waardering voor de agri en food sectoren scoort bovengemiddeld ten opzichte van referentiesectoren als IT, energie, textiel. Akkerbouw en tuinbouw worden het meest positief gewaardeerd en de intensieve veehouderij het minst positief (Agrofood Monitor, 2020). Zie figuur 5.6.

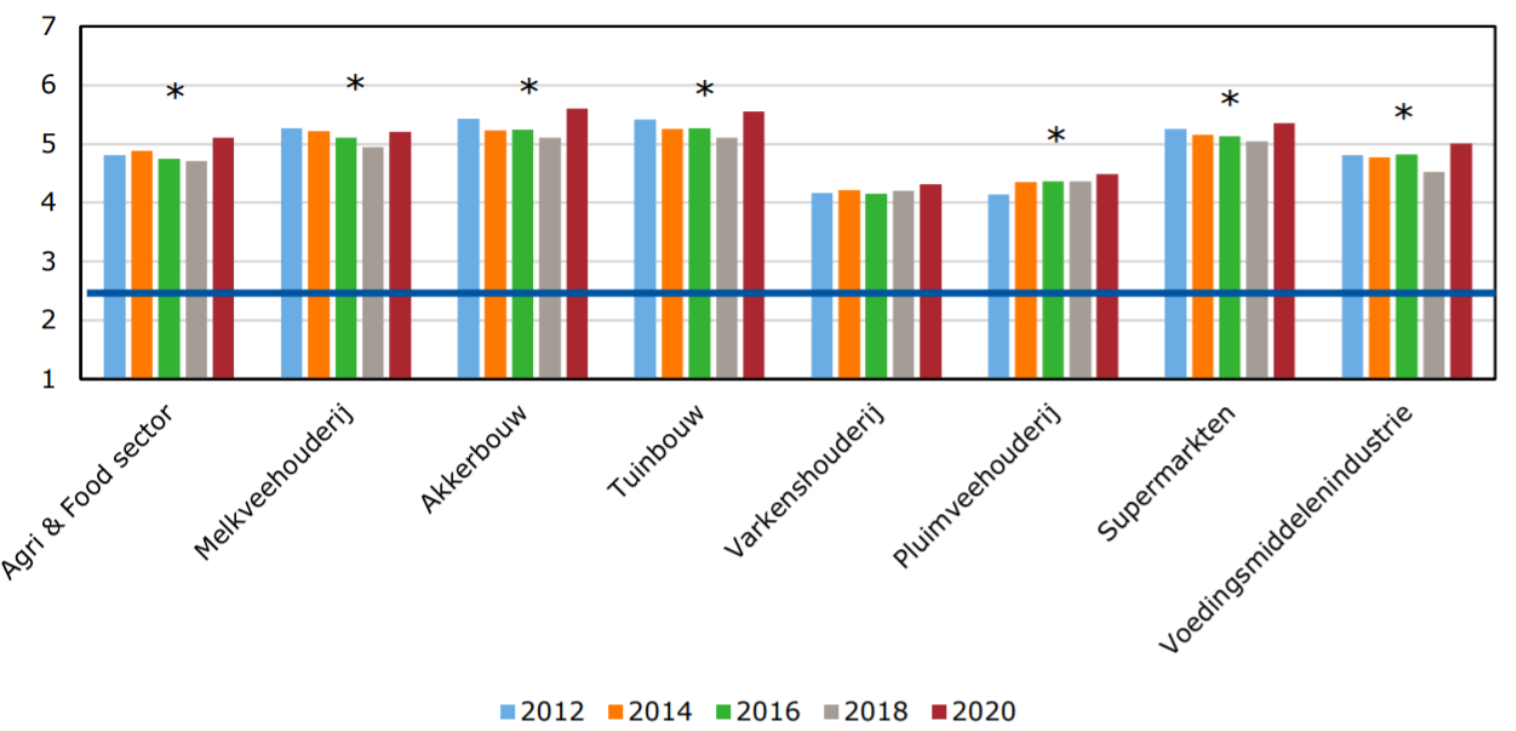

Figuur 5.6 Maatschappelijke waardering voor agro en food sectoren en haar subsectoren in de periode 2012-2020. De blauwe lijn geeft de neutrale score aan. *geeft aan dat er significante verschillen zijn tussen 2020 en (enkele) andere jaren. Bron: Agrofood Monitor, 2020.

De maatschappelijke waardering van de Agri \& Food-sector in het algemeen is positiever dan alle voorgaande jaren. De akkerbouw, tuinbouw, supermarkten (t.o.v. 2014, 2016, 2018), voedingsmiddelenindustrie (t.o.v. 2014, 2018), melkveehouderij (t.o.v. 2018) en pluimveehouder (t.o.v. 2012) laten allen een stijging in 2020 zien. De varkenshouderij blijft stabiel in 2020 t.o.v. de andere jaren.

Smaak, veilig, betaalbaar en gezond zijn (opnieuw) de belangrijkste voedselwaarden voor consumenten. De duurzaamheidswaarden scoren in de middenmoot. Een aantal egocentrische waarden (smaak, veilig, goed gevoel) is in 2020 weer belangrijker geworden (ten opzichte van 2012 en 2014 of 2016) voor consumenten. Duurzame waarden blijven even belangrijk. Met uitzondering van rechtvaardigheid, die in 2020 minder belangrijk is dan in 2016 en regio die belangrijker geworden is in 2020 (t.o.v. 2018) (Agrofood Monitor, 2020).

De Agrofood Monitor laat ook zien dat Covid-19 van invloed is op het eetpatroon. Het zijn geen grote verschuivingen, maar respondenten zijn bijvoorbeeld minder varkensvlees en meer groenten en fruit gaan eten. Zelf geven zij aan dat ze hun voedselaankopen in de periode sinds Covid-19 vooral doen vanuit gezondheid en duurzaamheid motivaties en omdat het betaalbaar is. Analyses laten echter zien dat met name de sociale omgeving (wat respondenten denken dat anderen voorstellen) van invloed is op veranderende voedselpatronen sinds Covid-19 (Agrofood Monitor, 2020). 


\subsubsection{Samenvatting sociaaleconomische factoren}

Vanwege de vraag naar grond voor o.a. woningen en duurzame energie (bijv zonnepanelen), de uitvoering van het natuurnetwerk Brabant en de bossenstrategie t.b.v. klimaatdoelstellingen zal het landbouwareaal afnemen. De productiviteit van het landbouwareaal staat onder druk door klimaatverandering, leidend tot toenemende droogte met name op de hoge zandgronden in Brabant. Dit kan leiden tot verdere afname van grond voor landbouwfuncties; inschatting van arealen zijn lastig te maken. Marktontwikkelingen zijn onzeker. De verwachting is dat internationale handel, zowel export als import een belangrijke rol blijven vervullen in zowel de primaire productie als in de consumptie. Er is een toenemende behoefte aan transparantie in (internationale) productieketens. De verbindingen met de stedelijke agglomeraties in de omgeving van Noord-Brabant worden verder ontwikkeld, via weg, spoor en door de lucht.

De verstedelijking en vergrijzing zullen doorzetten, in Nederland, maar ook in Noord-Brabant. De prognose is dat het percentage mensen in Noord-Brabant die buiten het actieve arbeidsproces zitten, aangegeven met 'groene druk' (mensen onder de 20 jaar) en 'grijze druk' (mensen boven de 65 jaar) de komende jaren zal stijgen naar respectievelijk 40 en $54 \%$.

(https://brabant.databank.nl/kiosken/index.html).

Er zal een beperkte bevolkingsgroei zijn, die voornamelijk afkomstig is van immigratie $\mathrm{Er}$ is sprake van een lichte verandering in consumptie naar meer gezonde voeding, naar lokale producten of meer duurzame producten. Hoewel consumenten aangeven dit belangrijk te vinden, is het aandeel van deze producten beperkt en wordt dit vooral gerealiseerd in hogere inkomensgroepen.

De maatschappelijke waardering voor de agri en food sectoren scoort bovengemiddeld ten opzichte van referentiesectoren als IT, energie, textiel. Akkerbouw en tuinbouw worden het meest positief gewaardeerd en de intensieve veehouderij het minst positief. Smaak, veilig, betaalbaar en gezond zijn (opnieuw) de belangrijkste voedselwaarden voor consumenten. De duurzaamheidswaarden scoren stabiel in de middenmoot (Agrofood Monitor, 2020).

De afstand tussen boer en burger en de kennis van consumenten over de oorsprong van hun voedsel staan onder druk, onder andere door verdergaande verstedelijking en de complexiteit van het agrofood systeem. Daarnaast past de verdergaande industrialisering van de land- en tuinbouw niet bij het ideaalbeeld van veel burgers.

\subsection{Milieufactoren}

\subsubsection{Klimaatverandering}

Klimaatverandering ontstaat door een stijging van de concentratie van broeikasgassen in de atmosfeer. De achtereenvolgende Assessment Reports van het Intergovernmental Panel on Climate Change (IPCC) geven een gedetailleerde beschrijving van de fysische achtergronden, historische ontwikkelingen en de bijdragen van de verschillende sectoren aan de toename van broeikasgassen. De klimaatverandering komt voor Nederland (en dus ook voor Noord-Brabant) neer op een aantal verschijnselen: een stijging van de gemiddelde temperatuur met zachte winters en warmere zomers, en een grotere kans op extremere weersomstandigheden, zoals het vaker voorkomen van regenbuien, die ook heftiger kunnen zijn dan voorheen, waardoor veel regenwater in korte tijd wegspoelt richting Noordzee ten koste van infiltratie op de plek waar het valt. Ook de kans op langduriger droogteperioden neemt toe. De stijging van de zeespiegel heeft vooral gevolgen via het optreden van zoute kwel in de kustgebieden en het binnendringen van zout water in de rivieren. De mogelijke verzilting is een risico dat in het westen van Noord-Brabant een rol kan spelen (Klimaatadaptatie Provincie Noord-Brabant, 2020).

Deze veranderingen kunnen invloed hebben op het agrofood systeem, op natuurlijke systemen en ook op de samenleving als geheel (IPCC, 2019). Ongeveer driekwart van Noord-Brabant bestaat uit (relatief) droogtegevoelige zandgronden. Op deze gronden is ook op dit moment alleen (intensieve) 
landbouw mogelijk door irrigatie met grond- en oppervlaktewater. Echter, bij toenemende en extremere droogte leidt het gebruik van grond- en oppervlaktewater tot problemen, zoals een dalende grondwaterspiegel, wat weer tot problemen leidt voor de drinkwatervoorziening en voor droogtegevoelige natuur. Als dat gaat leiden tot beperkingen van gebruik van grondwater in de landbouw, ontstaat er een serieus probleem: zonder irrigatie verdrogen gewassen op de zandgronden in korte tijd. Kortom: klimaatverandering en toenemende droogte is een serieuze bedreiging voor de huidige vorm van Brabantse landbouw op zandgronden, zeker als dit samengaat met een beperking van het watergebruik voor irrigatie.

Hoewel droogte al een serieus probleem is en nog zal toenemen, is er ook aandacht nodig voor de problemen met overvloedig water. Hevige regenbuien kunnen lokaal voor overstromingen zorgen, niet alleen van landbouwgrond, maar ook van bewoonde gebieden. De veranderingen in het klimaat komen snel en zijn in een aantal gevallen al zichtbaar en voelbaar. De rol van de landbouw in het bufferen van neerslagextremen, om zodoende bewoonde gebieden droog te houden, komt steeds meer in beeld. Een wat minder prominent, maar minstens zo schadelijk aspect van klimaatverandering zijn de extreme buien met hagel en windstoten, die vaak zeer plaatselijk voor grote schade zorgen aan gebouwen, kassen en gewassen. Een voorbeeld is de hagelbui in juni 2016 in de regio Someren/Luyksgestel die voor een miljoenenschade zorgde. Een verdere intensivering van de tuinbouw (van vollegronds- naar glastuinbouw) verhoogt dit risico.

Zowel droogte als wateroverlast als hagelbuien en stormschade zijn al voorgekomen. De provincie Noord-Brabant speelt al in op deze vraagstukken (Klimaatadaptatie provincie Noord-Brabant, 2020), in samenwerking met andere gemeenten, waterschappen, kennisinstellingen, ondernemers en sociale initiatieven. De klimaatadaptatie kan onder meer aanleiding zijn tot het (mede)gebruiken van (landbouw)grond voor waterberging. Daardoor neemt de aanspraak op landbouwgrond verder toe.

De klimaatverandering zal niet alleen leiden tot veranderingen in de landbouw. Ook de biodiversiteit/natuur in Brabant zal de gevolgen van klimaatverandering ondervinden. In hoeverre klimaat- en natuurdoelen leiden tot extra aanspraken op landbouwgrond is lastig te voorzien, maar alleen al de Brabantse bossenstrategie gaat uit van 5.000 ha nieuw bos buiten het Natuurnetwerk Noord-Brabant. Om de leefbaarheid in steden te verbeteren, zullen aanpassingen in ruimtelijke ontwerpen nodig zijn. Meer groen in de stad kan daar een bijdrage aan leveren. Dat vergt mogelijk meer ruimte voor stedelijke ontwikkeling, wat ook weer ten koste gaat van beschikbare grond voor landbouw.

Naast adaptatie (aanpassing) aan klimaatverandering, heeft de landbouw ook een opgave in het verminderen van de uitstoot van broeikasgassen. Het klimaatakkoord van Parijs stuurt aan op een klimaatneutrale samenleving waarbij de emissie en vastlegging van broeikasgassen in balans zijn. Afhankelijk van de ontwikkeling heeft dat gevolgen voor het grondgebruik, omdat bouwland, grasland en bos verschillende potenties hebben voor vastlegging van CO2 (Lesschen et al., 2020). Daarbij is het dilemma niet alleen dat deze grondgebruiksfuncties andere economische verdienmodellen hebben, maar ook omdat grasland ook sterk gekoppeld is aan rundveehouderij, die ook weer een forse bijdrage levert aan de emissie van broeikasgassen. Grasland zonder veehouderij is net als bos echter economisch erg kostbaar, zeker op dure Brabantse grond. Het is duidelijk dat klimaatadaptatie een grote inspanning van de landbouw vereist om die reductie in emissies te realiseren, zeker als de grondgebruiksfunctie (bouwland of grasland) niet verandert. Zo laat Lesschen et al (2020) zien dat de aanplant van bos op landbouwgrond een effectieve maatregel is om koolstofvastlegging te vergroten, dat daarnaast een belangrijke bijdrage levert aan biodiversiteit en klimaatadaptatie (met name infiltratie en water vasthouden in bodem). Meer bos kan ook in de vorm van agroforestry (de combinatie van bomen en teelt van eenjarige gewassen of begrazing) of voedselbosbouw (geïntegreerd productiesysteem met dominante rol voor houtachtige gewassen).

De noodzaak om de depositie van stikstof te verminderen (zie 3.3.1) zal leiden tot verdere inperking van de emissie van met name ammoniak uit de (melk)veehouderij, waarbij tegelijk niet maatschappelijk gewenst is dat dieren in dichte stallen gehouden worden. Nieuwe stalsystemen met primaire scheiding van mest en urine kunnen hier een rol in spelen, maar vragen ook investeringen van bedrijven. Nu de stikstofdoelen op de korte termijn gerealiseerd moeten worden, zal dat leiden 
tot een snelle herstructurering van de sector, omdat met name kleinere bedrijven deze investeringen niet meer zullen doen, terwijl grotere bedrijven mogelijk versneld investeren en verder groeien om de kosten terug te verdienen. Diverse regelingen (opkoop piekbelasters, extern salderen, sanering varkenshouderij) dragen bij aan de herstructurering en krimp van de veehouderij. Uit de verkenningen van de landbouwscenario's voor 2050 blijkt dat de reductie van de ammoniakemissie parallel kan lopen aan de vermindering van de emissies van methaan en lachgas (Lesschen et al., 2020).

\subsubsection{Biodiversiteit}

In paragraaf 3.3.2. wordt ingegaan op de teruglopende biodiversiteit in Brabant en welke maatregelen o.a. door de provincie zijn genomen om biodiversiteit te herstellen. De achteruitgang van de biodiversiteit wordt onder andere veroorzaakt door verstedelijking en landbouw. Beide zorgen voor een afname van het areaal aan natuurgebieden, milieudruk en versnippering van bestaande gebieden (Planbureau voor de Leefomgeving, 2014). Het is te verwachten dat klimaatverandering de achteruitgang van de biodiversiteit nog zal verergeren (Verboom et al., 2010). De stikstofdepositie in Natura2000 gebieden is ook in Brabant veel hoger dan de depositiedoelstellingen, die zijn gericht op het behoud en herstel van kwetsbare natuur. Deze depositie wordt deels veroorzaakt door ammoniakemissies uit de landbouw, naast emissies uit verkeer, industrie en achtergronddepositie uit het buitenland. Het besluit van de Raad van State over de Programmatische Aanpak Stikstof heeft geleid tot de stikstofcrisis in Nederland. De adviescommissie onder leiding van Remkes adviseert daarom maatregelen voor landbouw om de ammoniakemissie van de landbouw met 50\% te reduceren in 2030 en bedrijven naast N2000 gebieden uit te kopen. Dat heeft grote gevolgen voor Brabant, met een sterke concentratie van veehouderij én een aantal zeer kwetsbare N2000 gebieden. Zie ook paragraaf 3.3.2 (biodiversiteit) en figuur 3.15 waarin in het kader van de 'Brabantse Ontwikkelaanpak Stikstof $1.0^{\prime}$ een inschatting is gemaakt van de mate van overschrijding van gevoelige delen in Natura2000 gebieden in Brabant.

Biodiversiteit is meer dan alleen de diversiteit aan soorten. Het gaat om de diversiteit aan soorten die onderling in een samenhangend geheel - een ecosysteem - met elkaar en met hun omgeving verbonden zijn en zich voortplanten. Ecosysteemdiensten hebben maatschappelijk en economisch nut. Tastbare productiediensten zoals hout en voedsel zijn makkelijker in geld uit te drukken dan regulerende diensten zoals waterzuivering door een moeras, of culturele diensten zoals recreatie. Vaak wordt voor regulerende diensten weinig betaald (water) of niet betaald (lucht). Bij aantasting, door te intensief gebruik of vervuiling, worden herstelkosten vaak afgewenteld op de gemeenschap of op toekomstige generaties. Betalen voor gebruik van ecosysteemdiensten zou een oplossing kunnen zijn voor dit marktfalen (www.biodiversiteit.nl/biodiversiteit-is-levensbelang/ecosysteemdiensten). Bij het project 'Brabant's Bodem' wordt precies dat gedaan: de 50 aangesloten melkveehouders krijgen financiële vergoeding voor ecosysteemdiensten als biodiversiteitsherstel. Dit draagt bij aan nieuw perspectief voor boeren en draagt bij aan natuur en landschap. Wereldwijd wordt de waarde van ecosystemen in beeld gebracht in zgn. TEEB-studies (The Economics of Ecosystem Services).

\subsubsection{Bodemkwaliteit}

De bodemverdichting, de bodemgezondheid en de ontwikkeling van het organische stofgehalte van landbouwgrond is al in een eerder hoofdstuk aan de orde gekomen. Tegenover de vele alarmerende berichten over verarming en uitputting zet Ros (2020) een veel genuanceerder beeld: boeren zorgen relatief goed voor hun bodemvruchtbaarheid, die ondanks de aanscherping van het mestbeleid en de intensivering van het grondgebruik toch op peil blijft. Het opvallende is ook dat het alarmisme zich sterk richt op bodemvruchtbaarheid, maar de problematiek van bodemverdichting en bodemgezondheid lijkt te vergeten. Daar maken boeren zich juist zorgen over, omdat dit in toenemende mate schade geeft aan gewassen. De verhalen over 'dode landbouwbodems' geven overigens nog een andere trend aan, namelijk dat landbouwgronden steeds meer langs de maatlat van o.a. natuur- en bosgronden worden gelegd. De vraag of de bodembiologie aansluit bij de landbouwkundige functie wordt daarbij niet gesteld. Het laat wel zien dat er van agrarische grond ook andere functies worden verwacht, naast de landbouwproductiefunctie. Ros formuleert in zijn derde discussiebijdrage een raamwerk voor het realiseren van een goede bodemkwaliteit voor landbouw en andere maatschappelijke diensten. In het kort komt dat raamwerk neer op de volgende kernpunten: 
Een landbouwbodem is er primair voor gewasproductie: de kwaliteit van de grond moet dus primair vanuit deze functie worden beoordeeld en beheerd. De natuurlijke bodemvruchtbaarheid is leidend en hulpmiddelen als meststoffen, beregening of gewasbeschermingsmiddelen staan op de tweede plaats. Een landbouwbodem moet gevoed worden: het gaat om het scheppen van een balans voor mineralen, bodemstructuur en levende organismen in een bodem, zodat planten goed kunnen groeien en een actief bodemleven zorgt voor het beschikbaar maken van nutriënten en mogelijk ook het onderdrukken van ziekten en plagen. Een goed bouwplan, aansluitend bij de kwaliteit van de grond, met de optimale combinatie en volgorde van gewassen en groenbemesters, maar ook met de juiste rassen is de belangrijkste maatregel.

Een landbouwbodem heeft grenzen: een te intensief gebruik kan de draagkracht van een ecosysteem overstijgen, wat bovendien uiteindelijk een negatief effect kan hebben op opbrengsten. De keuze van goede bouwplannen is essentieel, niet alles kan overal worden geteeld.

Een landbouwbodem kan meer dan gewassen voeden. Sterker nog: de productiefunctie gaat altijd samen met effecten op grondwaterkwaliteit, biodiversiteit, waterbeheer en koolstofopslag. Dat kan positief zijn, maar dat hoeft niet: andere bodemdiensten hoeven niet persé in het verlengde te liggen van een landbouwkundig optimaal bodemgebruik. Het gaat dus ook om het maken van keuzes. Integraliteit en maatwerk zijn daarbij kernbegrippen.

Ros constateert dat er steeds meer eisen worden gesteld aan landbouwbodems. Hij benadrukt dat de doelen van de landbouwbodems helder moeten worden gemaakt en dat maatwerk belangrijk is. Maatwerk dat rekening houdt met de lokale omstandigheden van bodem en ecosysteem, met de bedrijfssituatie, de directe omgeving en de economische mogelijkheden. Als voorbeeld van doelen en maatwerk noemt Ros ook het (grond)water- en bodembeheer van de provincie Noord-Brabant.

\subsubsection{Samenvatting milieufactoren}

Klimaatverandering en waterbeheer zijn nu al grote uitdagingen op droogtegevoelige zandgronden in Noord-Brabant en de verwachting is dat in de komende jaren verder toeneemt. Percelen met onvoldoende waterbeschikbaarheid worden ongeschikt voor (dure) teelten, terwijl percelen met een goede waterbeschikbaarheid juist extra interessant worden voor land- en tuinbouw. Momenteel zijn economische principes bepalend voor de ruimtelijke ontwikkeling, maar het is de verwachting dat waterbeschikbaarheid steeds meer de grondgebruiksfunctie gaat bepalen.

Klimaatverandering zorgt voor een grote opgave in de landbouw om de uitstoot van broeikasgassen te verminderen. Het is de verwachting dat de omvang van de veestapel gaat afnemen, als gevolg van de huidige maatregelen (Sanering varkenshouderij, extern salderen met stikstof, opkoop regeling piekbelasters stikstof en mogelijk nog andere regelingen of maatregelen). Deze afname zal ook bijdragen aan de realisatie van de klimaat- en emissiedoelen. Ook zal reductie in emissies een grote inspanning van de landbouw vergen als de grondgebruiksfunctie (bouwland of grasland) niet verandert. Aanplant van bos op landbouwgrond is een effectieve maatregel om koolstofvastlegging te vergroten, dat daarnaast een belangrijke bijdrage levert aan biodiversiteit en klimaatadaptatie, met name infiltratie en water vasthouden in bodem (Lesschen et al, 2020). Meer bos kan ook in de vorm van agroforestry (de combinatie van bomen en teelt van eenjarige gewassen of begrazing) of voedselbosbouw (geïntegreerd productiesysteem met dominante rol voor houtachtige gewassen).

De biodiversiteit is in recente jaren sterk achteruitgegaan. De verwachting is dat klimaatverandering eveneens druk legt op de biodiversiteit. De stikstofdepositie, vanuit het buitenland, vanuit industrie en verkeer, maar ook vanuit landbouw (m.n. veehouderij) leidt tot het verlies van natuurkwaliteit. Om de stikstofnormen in N2000 gebieden te behalen, is een forse reductie van de ammoniakemissie uit de landbouw noodzakelijk. Dat kan grote gevolgen hebben voor de landbouw, en met name de veehouderij in Brabant.

De bodemkwaliteit blijft een punt van aandacht, ook omdat er naast de productiefunctie ook steeds meer andere diensten van landbouwgrond worden verwacht, zoals waterberging en koolstofvastlegging. Een integrale benadering daarbij ten aanzien van meerdere functies is belangrijk, evenals lokaal maatwerk, bijvoorbeeld via een gebiedsgerichte aanpak. 


\section{Kringlooplandbouw in Brabant}

De provincie Noord-Brabant streeft, in lijn met de landelijke visie 'Kringlooplandbouw', ook in Brabant naar een landbouw- en voedselsysteem waarvan de kringlopen gesloten zijn. Dit hoofdstuk geeft een aantal reflecties op dit streven, waarbij gebruik gemaakt is van De Boer \& Van Ittersum (2018), Leenstra et al (2017) en De Wolf et al (2019). Vanuit deze studies komt een aantal principes voor een circulair landbouw- en voedselsysteem naar voren:

Het primaire doel van een circulair systeem is het terugdringen van het gebruik van eindige hulpbronnen, zoals fossiele energie en fosfaat. Daarnaast draagt een circulair landbouwvoedselsysteem bij aan het waarborgen van natuurlijke hulpbronnen, zoals bodem, lucht, water, biodiversiteit en natuur.

Plantaardig voedsel boven dierlijk voedsel, zowel in productie als consumptie (De Boer \& van Ittersum, 2018)

Bijproducten uit de voedselketen moeten weer ingezet worden in het voedselsysteem (De Boer \& van Ittersum, 2018). Verspilling wordt tegengegaan.

Gebruik dieren voor dat waar ze goed in zijn (De Boer \& van Ittersum, 2018)

Kringlopen bestaan op meerdere schaalniveaus, van bedrijfsniveau tot mondiaal niveau, die allemaal met elkaar verbonden zijn (Leenstra et al, 2017)

In de landbouw-voedselkringloop zijn niet alleen bodem, gewassen, dieren en mest, maar ook industrie en consument opgenomen (de Wolf et al, 2019)

Deze principes worden kort uitgewerkt in een aantal reflecties in paragraaf 6.1. Daarna wordt specifiek ingegaan op het idee van regionale zelfvoorziening, met een wat uitgebreidere verkenning voor Brabant en Noordwest Europa.

\subsection{Enkele reflecties op het streven naar kringlooplandbouw}

\subsubsection{Wat is het doel van kringlooplandbouw?}

Sinds de lancering van de visie van het ministerie van LNV is kringlooplandbouw een populair begrip geworden. In alle enthousiasme kan het gebeuren dat kringlooplandbouw een doel in zichzelf gaat worden, terwijl het primaire doel van een circulair systeem gericht is op het terugdringen van het gebruik van eindige hulpbronnen. In de circulaire economie gaat het dan bijna uitsluitend over fossiele energie, terwijl het in de landbouw met name over nutriënten (stikstof en fosfaat) lijkt te gaan. Stikstof is geen eindige hulpbron, maar de productie van stikstofkunstmest is een energie-intensief proces.

Fosfaat is wel een eindige hulpbron, omdat fosfaatkunstmest gewonnen wordt uit fosfaatmijnen, waarbij zich in Nederland de merkwaardige situatie voordoet dat er een fosfaatoverschot bestaat, terwijl er nauwelijks fosfaatkunstmest wordt gebruikt (De Wolf et al, 2020). De verklaring is dat vrijwel alle fosfaat in het Nederlandse landbouwvoedselsysteem wordt geïmporteerd in de vorm van voedsel en veevoergrondstoffen. Die veevoergrondstoffen worden omgezet in dierlijke producten en mest, waarbij ongeveer $70 \%$ van de fosfaat in de mest terecht komt. In Nederland is zoveel dierlijke mest beschikbaar, dat dit voldoende is om alle Nederlandse landbouwgewassen van voldoende fosfaat te voorzien. Tegelijk is dit systeem ook volledig gebaseerd op kunstmestfosfaat: De Wolf et al (2020) laat ook zien dat de belangrijkste herkomstgebieden van veevoergrondstoffen een zeer lage veedichtheid hebben, en er is ook geen sprake van een retourstroom van fosfaatmeststoffen uit Nederland naar deze gebieden. 
Wie dus circulariteit wil bevorderen, doet er dus goed aan om zich daarbij tenminste twee doelen te stellen: 1. Vermindering van gebruik van fossiele energie en 2. Vermindering van het gebruik van import van veevoer. 3. Organiseren van retourstromen voor externe inputs.

\subsubsection{Plantaardig boven dierlijk voedsel}

Een ander belangrijk uitgangspunt van een circulair landbouw-voedselsysteem is dat plantaardig boven dierlijk voedsel gaat. Dat betekent aan de ene kant dat landbouwgrond zoveel mogelijk wordt gebruikt voor voedselproductie, en niet voor veevoerproductie. Dat kan niet op alle gronden, zoals veengrond of hele zware klei, maar juist in Brabant zijn de dekzandgronden (midden- en oostBrabant) en de kleigronden (West-Brabant) bij uitstek geschikt voor voedselproductie. Overigens geldt wel dat de teelt van veel akkerbouw- en groentegewassen, zoals aardappelen, uien, suikerbieten en peen in een vruchtwisseling afgewisseld moet worden met zogenaamde rustgewassen (granen, grassen, eiwitgewassen). Deze rustgewassen zijn vaak minder of niet geschikt voor humane consumptie. Dat geldt overigens ook voor allerlei industriële reststromen bij de verwerking van voedselgewassen, zoals suikerbieten, fritesaardappelen of brouwgerst. Daardoor zal ook een productiesysteem wat maximaal op voedselproductie is gericht, toch veevoergrondstoffen produceren.

Ook in de consumptie vanuit circulair perspectief gaat plantaardig boven dierlijk voedsel: het is efficiënter om rechtstreeks plantaardig eiwit te consumeren en dit niet te voeren aan dieren, om vervolgens dierlijke producten te consumeren. De realiteit is dat deze eiwittransitie nog in de kinderschoenen staat en dat Europeanen relatief veel dierlijk eiwit consumeren. Dat betekent ook dat er nog steeds een grote afzetmarkt is voor dierlijke producten. Nederland, en Brabant in het bijzonder, speelt een belangrijke rol in de productie en export van dierlijke producten.

Het mag duidelijk zijn dat zowel op de productie (voedsel versus veevoer) als op de consumptie nauwelijks of niet te sturen is, zeker niet op regionaal niveau. Daarnaast zou dit in de huidige context betekenen dat een krimp van de veehouderij in Brabant leidt tot een groei van de veehouderij op een andere plaats (buiten Nederland), omdat de marktvraag niet opeens verandert.

\subsubsection{Inzet van reststromen}

Hoewel vaak wordt gedacht dat het voedselsysteem veel verliezen heeft, is dat maar deels terecht. Er gaat relatief weinig verloren in de keten van productie tot retail, maar met name van retail tot consument zijn de verliezen veel groter. Daarnaast blijkt dat alle nutriënten die Nederlanders via voedsel consumeren, niet meer terugkeren in de landbouw-voedselkringloop.

Nederland, en Brabant in het bijzonder, zijn een goed voorbeeld van een maximale benutting van alle rest- en bijproducten die in de verwerking van plantaardige en dierlijke producten ontstaan. Keer op keer blijkt dat hier eigenlijk niets meer valt te verbeteren (Vijn et al, 2019). Er zijn slechts enkele lastige reststromen, zoals slachtafval en swill, die om voedselveiligheids- en diergezondsheidsredenen niet gebruikt mogen worden als veevoergrondstof.

De verspilling bij de consument is een grote uitdaging. Daarbij is het echter belangrijk om de verspilling fors terug te dringen, naast het collecteren en benutten van deze stroom. De grootste en meest relevante uitdaging is echter om de nutriënten uit het humane afvalsysteem terug te brengen in het landbouw-voedselsysteem. Dat is om allerlei redenen nog niet mogelijk, o.a. vanwege de verontreiniging van deze stromen met zware metalen, medicijnen en hormonen. Daarnaast zijn de kosten voor terugwinning hoog, en is de markt verzadigd met een (over)aanbod van goedkope dierlijke meststoffen.

\subsubsection{Gebruik dieren waar ze goed in zijn}

Dit principe sluit aan op het tweede principe (voedsel boven veevoer). Het is vanuit circulair oogpunt belangrijk om herkauwers te benutten om gras (voor mensen oneetbaar) te eten, geproduceerd op gronden die voor voedselproductie ongeschikt zijn. Daarnaast zijn veel landbouwhuisdieren bij uitstek geschikt om allerlei reststromen te verwerken, wat overigens al op grote schaal gebeurt. Tegelijk zijn deze dieren genetisch zo doorontwikkeld, dat ze optimaal produceren op een stabiel, hoogwaardig rantsoen. Dat gaat moeilijk samen met een wisselend rantsoen van allerlei meer laagwaardige inputs. 
Feitelijk vraagt dit uitgangspunt om een heel ander veehouderijsysteem, wat gebaseerd is op het beschikbare aanbod van voor mensen oneetbare grondstoffen. Dat zou, zeker in combinatie met de eiwittransitie bij de consument, leiden tot een veel kleinere veestapel in Nederland, en zeker in Brabant.

In het benutten van reststromen komen niet alleen de traditionele landbouwhuisdieren in beeld: ook andere organismen worden ingezet om voor mensen oneetbare stromen te bewerken of te verwaarden, zoals insecten, algen of schimmels. Dat levert ook nieuwe bedrijvigheid op, zoals het bedrijf Protix in Bergen op Zoom.

\subsubsection{Schaalniveaus in de kringloop}

Zoals de fosfaatkringloop al laat zien, is Nederland, en ook Brabant, onderdeel van een veel grotere kringloop, via import van veevoer en voedsel en export van landbouwproducten. Daar zit ook de grootste uitdaging: op bedrijfsniveau en regionaal niveau zijn de kringlopen tussen plantaardige en dierlijke productie, maar ook met de verwerkende industrie sterk ontwikkeld en geoptimaliseerd, maar door alle import van veevoer en voedsel is Nederland (en zeker ook Brabant) een concentratiepunt van nutriënten in de vorm van dierlijke mest en humane reststromen.

Zoals De Wolf et al (2020) laat zien, is het verminderen van de regionale dichtheid van de veehouderij een gedeeltelijke oplossing voor dit concentratieprobleem, maar blijft de concentratie in stedelijk gebied bestaan. Daarom is het belangrijk om de humane reststromen weer geschikt te maken voor gebruik in de landbouw. Overigens leidt het verkleinen van de veestapel in Brabant wel tot oplossing van een aantal regionale duurzaamheidsvraagstukken, maar leidt het ook gemakkelijk tot afwenteling naar andere regio's waar de veehouderij groeit (als de vraag naar dierlijke producten gelijk blijft). Een ander punt op regionale schaal is het terugdringen van emissies: vanuit circulair oogpunt is het terugdringen van verliezen cruciaal, omdat dit direct de afhankelijkheid van inputs vermindert. In een intensief landbouwgebied als Noord-Brabant is dit een belangrijk aandachtspunt, ook omdat deze emissies allerlei negatieve gevolgen hebben, o.a. voor biodiversiteit en waterkwaliteit.

Een belangrijke kanttekening bij de schaalniveaus is dat deze ook sterk samenhangen met de bestuurlijke niveaus: een provincie heeft invloed op de kringloop in de regio, maar niet of nauwelijks op de kringloop op de schaal van Noordwest Europa. In dit opzicht is ook de Nederlandse overheid maar beperkt in staat om de internationale landbouwvoedselkringloop te sturen waar Nederland slechts onderdeel van is.

\subsubsection{De schakels in de kringloop}

Brabant is een goed voorbeeld van de sterke verwevenheid van sectoren in de kringloop: veehouderij en plantaardige bedrijven wisselen grond, voer en mest uit en allerlei industriële reststromen uit de verwerking van agrarische producten worden weer benut als veevoer of meststof. Deze verwevenheid heeft ook allerlei afhankelijkheden in zich: zo zal de krimp van de veehouderij direct gevolgen hebben voor de mestbeschikbaarheid in plantaardige sectoren en zal een verschuiving in teelten weer leiden tot andere ketens met andere reststromen. Het risico van allerlei sectoraal beleid is dus dat de consequenties in andere sectoren over het hoofd worden gezien. De recente discussie over de contouren van het nieuwe mestbeleid van LNV zijn daar een goed voorbeeld van: als melkveehouders alle mest op het eigen bedrijf moeten plaatsen (grondgebondenheid), kunnen akkerbouwgebieden als Zeeland of Flevoland opeens niet meer beschikken over voldoende rundveemest.

Zoals al bij 6.1.3 gezegd, is de kringloop met de consument niet gesloten: vrijwel alle nutriënten die de consument via voedsel binnenkrijgt, komen niet meer terug in de landbouw. Daarnaast is het voedselsysteem zo georganiseerd, dat er op regionale en zelfs nationale schaal geen directe koppeling is tussen productie en consumptie. Het kan dus dat Nederland consumptieaardappelen of vlees exporteert naar buurlanden en tegelijk ook deze producten importeert voor eigen consumptie. Dat betekent niet alleen dat een fysieke nutriëntenkringloop met retourstromen tussen producent en consument onmogelijk is, maar ook dat allerlei ideeën over regionale zelfvoorziening van voedsel niet direct aansluiten op de realiteit. Dat wordt verder verkend in paragraaf 6.2. 


\subsubsection{Bespiegelingen over een circulair landbouwvoedselsysteem}

Bovenstaande geeft aan dat, hoe wenselijk en gedragen een transitie naar circulariteit ook gevonden wordt, het vertalen van de circulariteitsprincipes naar de praktijk behoorlijke consequenties kan hebben. Als we bijvoorbeeld dieren alleen op basis van reststromen en marginale graslanden gaan voeren, heeft dat grote gevolgen voor het aantal dieren dat we in Europa kunnen houden (namelijk volume reststromen bepaalt het aantal dieren en niet andersom, nog los van de meer fundamentele vraag wat we onder een reststroom verstaan) en voor de hoeveelheid dierlijke producten die we kunnen consumeren. Recent onderzoek toonde aan dat wanneer we dieren enkel voeren met reststromen en gras, we in Europa ongeveer de helft minder dierlijke producten kunnen eten (de Boer et al, 2020). Beide gevolgen passen dan wel weer in de grote maatschappelijke opgaven die er zijn op het gebied van reductie van stikstofemissies, en op het gebied van het streven naar een 'planetary health diet'. Daarnaast heeft een circulair voedselsysteem grote economische consequenties, bijvoorbeeld voor de diervoederindustrie en de zuivel- en vleessector. Ook ruimtelijk en landschappelijk zou deze transitie grote gevolgen hebben. Als daarnaast, zoals in de kringlooplandbouwvisie van minister Schouten staat, de kringlopen op een zo laag mogelijk schaalniveau gesloten moeten worden, betekent dit dat voedsel dat in Nederland wordt geproduceerd ook in Nederland zou moeten worden geconsumeerd. Wat dit betekent en of dit haalbaar is, wordt verkend in paragraaf 6.2 .

Alles overwegend, is een circulair perspectief zinvol om het huidige agrofoodsysteem te analyseren en de samenhang tussen sectoren en tussen verschillende schaalniveaus te zien. Tegelijk is de complexiteit van de verschillende sectoren en schaalniveaus ook wel zo groot dat het niet eenvoudig is om hier concreet beleid op te ontwikkelen. Dat wordt nog versterkt door de grote afstand tussen de realiteit en een visie vanuit circulair perspectief. Hoe aantrekkelijk zo'n visie ook klinkt, het is erg lastig om concreet te bedenken hoe deze vanuit de realiteit van vandaag gerealiseerd moet worden. Het huidige agrofood systeem is namelijk niet vanuit circulaire, maar vanuit economische principes georganiseerd.

Wel zinvol is verder te investeren in pilots (niche-experimenten) op het gebied van circulariteit, mits deze gericht zijn op de transitie-opgaven in het systeem. Denk hierbij aan het experimenteren met nieuwe meststoffen uit de humane afvalketen of het inzetten van insecten om reststromen op te waarderen tot bruikbare grondstoffen in de voedselproductie. Hierbij past tegelijk de kanttekening dat veel 'experimenten' onder de noemer van kringlooplandbouw of circulariteit worden gebracht, die zich vooral richten op het in stand houden van het huidige model. Betere benutting van dierlijke mest door mestbewerking is in principe niet verkeerd, maar één van de transitie-opgaven is dat de veehouderijsector qua omvang niet aansluit op de beschikbare grond in de regio, zowel vanuit mestbehoefte als vanuit voerproductie. Een niche-experiment zou dus kunnen gaan over een systeem waarbij dierlijke productie ten dienste staat van een duurzaam plantaardig productiesysteem, als verwerker van voor mensen oneetbare reststromen uit plantaardige productie. Zo'n systeem is vernieuwend, risicovol en economisch (nog) niet haalbaar, en verdient dus experimenteerruimte en facilitering om zich te kunnen ontwikkelen.

\subsubsection{Samenvatting}

De provincie Noord-Brabant streeft, in lijn met de landelijke visie 'Kringlooplandbouw', ook in Brabant naar een landbouw- en voedselsysteem waarvan de kringlopen gesloten zijn. Dit hoofdstuk geeft een aantal reflecties op dit streven, waarbij gebruik gemaakt is van De Boer \& Van Ittersum (2018), Leenstra et al (2017) en De Wolf et al (2020). Vanuit deze studies komt een aantal principes naar voren:

Het primaire doel van een circulair systeem is het terugdringen van het gebruik van eindige hulpbronnen, zoals fossiele energie en fosfaat. Daarnaast draagt een circulair landbouwvoedselsysteem bij aan het waarborgen van natuurlijke hulpbronnen, zoals bodem, lucht, water, biodiversiteit en natuur.

Plantaardig voedsel boven dierlijk voedsel, zowel in productie als consumptie (De Boer \& van Ittersum, 2018). 
Bijproducten uit de voedselketen moeten weer ingezet worden in het voedselsysteem (De Boer \& van Ittersum, 2018). Verspilling wordt tegengegaan.

Gebruik dieren voor dat waar ze goed in zijn (De Boer \& van Ittersum, 2018)

Kringlopen bestaan op meerdere schaalniveaus, van bedrijfsniveau tot mondiaal niveau, die allemaal met elkaar verbonden zijn (Leenstra et al, 2017)

In de landbouw-voedselkringloop zijn niet alleen bodem, gewassen, dieren en mest, maar ook industrie en consument opgenomen (de Wolf et al, 2020)

Het huidige agrofood systeem is vooral op economische, niet op circulaire, principes ontwikkeld. Vertaling van circulariteitsprincipes naar de praktijk heeft grote gevolgen: zowel economisch (bijvoorbeeld voor de diervoederindustrie en de zuivel- en vleessector) als ruimtelijk (landbouwgrond wordt vooral gebruikt voor humane voedselgewassen, meer diversiteit aan gewassen). Recent onderzoek toonde aan dat wanneer we dieren enkel voeren met reststromen en gras, we in Europa ongeveer de helft minder dierlijke producten kunnen eten (de Boer et al, 2020). Een consumptiepatroon met minder dierlijke producten past goed bij het streven naar een 'planetary health diet' en een kleinere veehouderij zou ook bij kunnen dragen aan de reductie van o.a. stikstofemissies. Tegelijk is het een misverstand dat het ingrijpen in de productiekant, bijv. op de schaal van Nederland of zelfs in Europa, zou leiden tot een ander consumptiepatroon en daarmee tot een mondiaal kleinere veehouderij. Als de consumptie van dierlijke producten niet verandert, zal een regionale of nationale krimp van de dierlijke productie slechts leiden tot verplaatsing naar andere regio's/landen en meer import.

Hoewel er in Brabant diverse initiatieven zijn op het gebied van circulariteit (Bijv. Kipster, Cosun) en diverse proeftuinen (bijv Agroproeftuin de Peel) en expertise centra (bijv. CBBE, lectoraten HAS Hogeschool) is een transitie naar een circulair agrofood systeem nauwelijks te sturen op provinciaal niveau, omdat het systeem op een veel grotere ruimtelijke schaal is georganiseerd.

\subsection{Een blik vooruit: voedselvoorziening in Noordwest Europa}

In het kader van het sluiten van kringlopen en het verminderen van voedselkilometers worden er veel activiteiten gericht op het lokaal produceren en consumeren van voedselproducten. Tevens is er veel aandacht voor een aanpassing van de consumptie om land- en watergebruik en emissies van ons eetpatroon te verminderen. Dit hoofdstuk geeft een aantal oriënterende berekeningen om te laten zien wat het huidige en een toekomstig dieet betekenen voor de zelfvoorziening in Europa en de mogelijkheden om in Noord-Brabant de eigen productie te consumeren. Dit was één van de vragen van de Provincie voor deze studie. Zelfvoorziening hier is opgevat als 'zijn productie en consumptie op de schaal van NB en NWE in evenwicht te brengen', waarbij is aangenomen dat er geen import/export over de buitengrenzen plaatsvindt. Het is daarmee wel een theoretische verkenning.

\subsubsection{Het huidige en toekomstige dieet}

De inname van eiwit in het huidige dieet in NWE, NL en NB bedraagt meer dan 100 gram per persoon per dag (Tabel 1), waarvan ongeveer twee derde bestaat uit dierlijk eiwit. De dagelijkse eiwitbehoefte van volwassenen ligt rond de 60 gram per persoon per dag. De overconsumptie bedraagt dus ongeveer $75 \%$. De dagelijkse energiebehoefte, gebaseerd op gemiddelde lichamelijke inspanning bedraagt 2500 kilocalorieën voor een volwassen persoon. De inname van energie ligt daar 30 tot $40 \%$ boven, ruim meer dan $3000 \mathrm{kcal}$. Zelfs als er $10 \%$ extra energie nodig is voor sport, werk, fietsen voor woon-werkverkeer, dan nog is er sprake van een forse overconsumptie. 


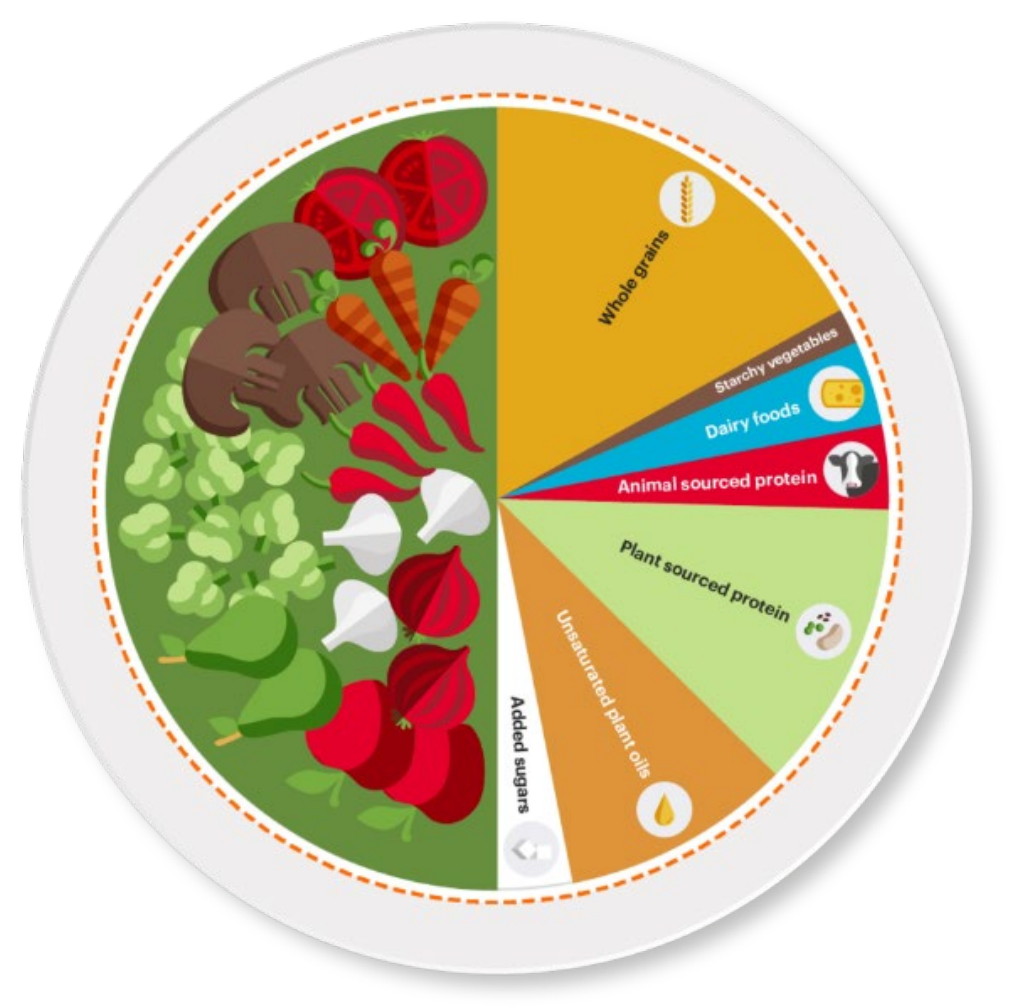

Figuur 6.1 het Planetary health diet (EAT Lancet, 2019).

In 2019 maakte een grote groep wetenschappers het planetary health diet: een referentie voedingspatroon van een gezond én duurzaam menu. Dit menu bestaat voor de helft uit groenten en fruit, de andere helft bestaat voornamelijk uit volkorengranen, plantaardige eiwitten, onverzadigde plantaardige olie, en een bescheiden hoeveelheid melkproducten en vlees. Zie figuur 6.1 (www.eatforum.org).

Als het EAT-Lancet voedingspatroon (Willet et al., 2019) als inspiratiebron wordt genomen, dan moeten de bovengenoemde waarden fors worden gereduceerd, vooral door voedsel van dierlijke oorsprong te verminderen. Dat is gedaan in het dieet "streven 2040". De eiwitconsumptie wordt dan slechts voor een kwart gedekt uit dierlijk eiwit. Dat is gedaan door alle dierlijk eiwit, met uitzondering van vis, terug te brengen naar $20 \%$ van het huidige niveau (Tabel 1). Tegelijk is de eiwitinname uit groenten met $25 \%$ verhoogd, terwijl de consumptie van peulvruchten met een factor 10 toeneemt. De eiwitinname is nog wel boven de minimale waarde. De energieconsumptie is teruggebracht tot 10 $\%$ boven het onderhoudsniveau. Dat wordt gedaan door de consumptie van alcohol en suikers te halveren en de consumptie van granen met $25 \%$ te verhogen. Ook de verhoogde consumptie van groenten draagt bij aan de energie-inname. 
Tabel 3 Huidige en geprojecteerde inname van energie en eiwit door consumenten in NWE, NL en NB (Bron FAOstat en berekening op basis van EAT-Lancet dieet).

\begin{tabular}{|l|c|c|c|c|}
\hline & \multicolumn{2}{|l|}{ NWE } & NL/NB & \\
\hline Situatie2016 & Energie(kcal/d) & Eiwit(g/d) & Energie(kcal/d) & Eiwit(g/d) \\
\hline Dierlijk & 1116 & 65 & 1085 & 35 \\
\hline Plantaardig & 2415 & 41 & 2153 & 105 \\
\hline Totaal & 3531 & 106 & 3238 & \\
\hline Streven2040 & Energie & & & Eiwit \\
\hline Dierlijk & 262 & Eiwit & Energie & 19 \\
\hline Plantaardig & 2493 & 18 & 254 & 57 \\
\hline Totaal & 2755 & 77 & 2429 & 76 \\
\hline
\end{tabular}

\subsubsection{Productie en handel in Noordwest Europa}

Om inzicht te krijgen in de zelfvoorziening en de beschikbaarheid van voedsel is het van belang om een beeld te hebben van de productie en de in- en uitvoer van producten en grondstoffen. Dan kan worden gekeken of het mogelijk is om het betreffende gebied zelfvoorzienend zou kunnen worden. Dat is geen verplichting, maar een inschatting of het een realistisch doel is of juist niet.

De productie in NWE bedraagt 360 Megaton aan dierlijke en plantaardige producten. De import en export is groot, 215 Megaton wordt geëxporteerd, terwijl er 206 Megaton wordt geïmporteerd, inclusief veevoergrondstoffen (Tabel 2). De netto export is slechts 10 Megaton. Gesplitst naar voedsel en veevoer blijkt dat er netto 36 Megaton aan voedsel wordt geëxporteerd en netto 26 Megaton aan veevoer wordt geïmporteerd. In totaal is er 322 Megaton beschikbaar voor voedsel en veevoer. Om een indruk te geven van de daadwerkelijke stromen: bij alle granen is de export 183 megaton en de import 137 megaton, voor melk is dat respectievelijk 153 en 80 megaton, voor aardappelen 53 en 24 megaton en voor groenten 55 en 74 megaton.

In Nederland bedraagt de productie 44 Megaton aan dierlijke en plantaardige producten. De import en export is zelfs groter dan de totale productie wat er op wijst dat er sprake is van een grote doorvoer. De import en export bedragen respectievelijk ruim 51 Megaton en bijna 54 Megaton. De netto export is ruim 2 Megaton, waarvan bijna 16 Megaton export van voedsel en ruim 13 Megaton invoer van veevoer. In totaal is er 38 Megaton beschikbaar voor voedsel en veevoer.

In theorie kunnen Nederland en NWE zelfvoorzienend zijn, als je alleen kijkt naar de hoeveelheid aan producten. De enorme handel betreft niet alleen dierlijke producten en veevoer, maar ook grote hoeveelheden ander voedsel. Daarbij valt ook te denken aan tropisch fruit, zoals sinaasappels, kiwi's, koffie, thee, chocolade en verse sperziebonen in ons winterseizoen. Berekeningen tonen aan dat zelfvoorziening inderdaad mogelijk is, zij het met sobere diëten (van Kernebeek et al., 2016; Terluin et al., 2013). Dit antwoord is in deze berekening niet te geven voor Noord-Brabant. 
Tabel 4 Productie, in- en uitvoer in NWE, uitgedrukt in Megaton product. Gemiddelde van 2015 2018. Bron: FAOstat database.

\begin{tabular}{lcc} 
& NL (Mton product) \\
Totale productie & +359 & +44 \\
\hline Import & +205 & -51 \\
\hline Export & -215 & -54 \\
\hline Netto Export & -36 & -3 \\
\hline Waarvan voedsel & +26 & -16 \\
\hline Waarvan veevoer & +347 & 13 \\
\hline Beschikbaar voor voedsel en voer* & 185 & +38 \\
\hline Waarvan Voedsel* & 98 & 17 \\
\hline Waarvan Voer* & & 16 \\
\hline$*:$ verschillen in de balans ontstaan door verliezen, voorraadverschillen, non-food & \\
toepassingen, fouten in de basisgegevens en afrondingen op hele Megatonnen & \\
\hline
\end{tabular}

In de huidige situatie zijn zowel Noordwest Europa als Nederland netto exporteurs, wat in principe betekent dat er ruimte zou zijn voor zelfvoorziening voor voedsel. Een groot deel van de voedselimporten kan niet in Noordwest Europa worden geproduceerd, de helft daarvan is fruit (12 Megaton), een kwart is groenten (6 Megaton) en daarnaast betreft het onder meer pasta (van harde tarwe) en rijst. Nederland is een netto exporteur van groenten, terwijl Noordwest Europa als geheel een netto importeur is.

Als de consumptie sterk verandert, kan worden verkend wat dat betekent voor de productie en de gerelateerde handel. In die berekening is een aantal aannames gedaan:

Alle veranderingen in consumptie worden vertaald naar een verandering in de beschikbaarheid van voedsel. Dat geldt zowel voor de dierlijke als de plantaardige producten. Daarbij neemt de consumptie van dierlijke producten af tot $20 \%$ van het huidige niveau en neemt de consumptie van plantaardige producten toe met $25 \%$, behalve die van peulvruchten, deze neemt toe met $900 \%$ (dus 10 keer zoveel als nu).

Omdat de consumptie van dierlijk eiwit naar $20 \%$ gaat, wordt ook de dierlijke productie naar verhouding ingekrompen. De hoeveelheid producten die nodig is voor veevoer wordt naar verhouding aangepast. Uiteraard is dit een grove aanname.

De plantaardige productie in NWE gaat terug naar $70 \%$ van het huidige volume, door een daling van de productie per hectare met $30 \%$. De bodemproductiviteit van biologische landbouw is ongeveer 20 $\%$ lager dan van gangbare landbouw. Daar wordt nog een daling van de productiviteit van $10 \%$ aan toegevoegd voor klimaatverandering door toenemende vochttekorten.

De beschikbaarheid van groenten, granen en andere producten is afhankelijk van de productie en, als dat niet genoeg is, wordt er geïmporteerd. Als er meer wordt geproduceerd dan nodig is, wordt er geëxporteerd. Het areaal van gewassen wordt in deze berekening niet aangepast.

In de aannames is de economische realiteit uitgeschakeld. Het is daarmee een denkoefening om te zien wat er technisch haalbaar is met betrekking tot de voedselproductie in NWE. Het resultaat van deze berekening is te zien in tabel 5 . 
Tabel 5 Productie, in- en uitvoer in NWE, uitgedrukt in Megaton product. Berekening aan de hand van wijziging in de diëten van de inwoners.

\begin{tabular}{|c|c|c|}
\hline & NWE (Mton product) & NL (Mton product) \\
\hline Totale productie & +196 & +22 \\
\hline Import & 36 & 3 \\
\hline Netto Export & -41 & -10 \\
\hline Waarvan voedsel & NA & NA \\
\hline Beschikbaar voor voedsel en voer* & 155 & 13 \\
\hline Waarvan Voedsel & 132 & 12 \\
\hline Waarvan Voer & 12 & 1 \\
\hline \multicolumn{3}{|c|}{$\begin{array}{l}\text { *: verschillen in de balans ontstaan door verliezen, } \\
\text { voorraadverschillen, non-food toepassingen en afrondingen op } \\
\text { hele Megatonnen }\end{array}$} \\
\hline
\end{tabular}

Het plaatje voor NWE ziet er dan heel anders uit. Het gebied is een grotere netto-exporteur geworden. Dat wordt vooral veroorzaakt door het sterk afgenomen gebruik van granen voor veevoer (netto export is nu 47 megaton). De consumptie van dierlijk eiwit is nog iets kleiner dan de productie, waardoor er per saldo ook vlees en met name melk geëxporteerd kan worden ( 8 megaton). NWE is wel een grote netto importeur van groenten en fruit (30 megaton). De totale hoeveelheid benodigd voedsel neemt af van 155 Megaton naar 132 Megaton, terwijl de hoeveelheid veevoer (exclusief gras en voedergewassen) daalt van 98 naar 12 megaton. Het veevoer bestaat dan alleen uit de bijproducten van de voedsel en dranken industrie en niet meer uit primaire gewassen.

Voor Nederland zou de daling neerkomen op een daling van de vraag naar voedsel van 17 naar 12 megaton en voor veevoer van 16 naar 1 megaton. Ook hier bestaat het veevoer (naast gras en voedergewassen) alleen uit bijproducten van de voedsel- en dranken industrie.

Uiteraard zijn deze getallen erg ruw en onnauwkeurig, maar ze even wel een aantal belangrijke indicaties:

De sterke krimp van de dierlijke productie leidt (bij gelijkblijvend landbouwareaal) tot een grote beschikbaarheid van plantaardige producten. Deze zijn niet direct geschikt voor humane consumptie, maar door aanpassing van het bouwplan kunnen de granen worden vervangen door bijvoorbeeld groenten.

De veranderingen in dierlijke productie, maar ook de hierboven genoemde verschuiving in plantaardige productie en tevens het verkopen van al deze producten via retail vergt een sterke sturing van een overheid in het gehele agrofood systeem. Daarmee wordt de marktwerking volledig uitgeschakeld.

Op netto niveau zou Noordwest Europa en ook Nederland nog wel zelfvoorzienend kunnen zijn, maar dat betekent een drastische aanpassing van het dieet, waarbij veel groenten, fruit, pasta en rijst vervangen moeten worden door lokale producten. Ook luxe producten, zoals koffie en chocola zitten dan niet meer in het dieet. Het betekent dat het niet voldoende is om alleen naar de hoeveelheden in Megatonnen te kijken. Hoeveelheden suggereren een uitwisselbaarheid die er niet is. Aardappelen en bananen zijn verschillende producten met een verschillende voedingswaarde en beleving en ook met een verschillend landgebruik in vierkante meters per $\mathrm{kg}$ product. Het is dus belangrijk om ook naar het landgebruik te kijken.

Als de tropische producten in ogenschouw worden genomen en alleen deze van buiten Europa komen, is het in theorie mogelijk dat ongeveer $80 \%$ van de voedselproductie in Noordwest Europa gerealiseerd kan worden.

Voor het behoud van een gevarieerd dieet is het zelfs op niveau van Noordwest Europa gewenst om internationale handel in voedsel te bedrijven.

\subsubsection{Genoeg land voor zelfvoorziening?}

Er zijn geen gedetailleerde voedselbalansen te maken voor Brabant. Er is wel een tweede benadering mogelijk die gebruikt kan worden om te zien in hoeverre de regio Noordwest Europa en ook NoordBrabant zelfvoorzienend kunnen zijn. Dat wordt dan ingeschat op basis van het landgebruik. 
Er is in NWE gemiddeld 0.29 hectare land per hoofd van de bevolking beschikbaar in 2016. Daarbinnen zijn grote verschillen met Ierland als topper met 0.95 hectare per persoon en Noord Brabant als laagste met 0.09 per persoon in 2016. Dit zijn alleen hectares, deze zeggen nog niets over wat er geteeld kan worden. Ierland bestaat voor het overgrote deel uit grasland, akkerbouw is daar beperkt mogelijk.

In de periode tot 2040 is er nog sprake van een beperkte groei van de bevolking (ontleend aan de bevolkingsprognoses van de VN). Het areaal landbouwgrond wordt geacht overal te dalen met $0.33 \%$ per jaar voor woningen, bedrijventerreinen, natuur, herbebossing en eventueel andere bestemmingen. Door deze twee ontwikkelingen daalt de beschikbare grond tot 0.26 hectare per hoofd van de bevolking in 2040. In 2040 is dat in Noord-Brabant afgenomen tot 0.06 hectare.

Als dat wordt vergeleken met de oppervlakte die nodig is voor een duurzaam dieet van 0.11 hectare (Westhoek, 2019), dan moet zelfs bij een optimale inrichting van het land en een maximale sturing van de markt nog ongeveer de helft van het voedsel van buiten de provincie komen. Daarbij zal een groot deel van de zandgronden niet geschikt zijn voor bouwland, wat betekent dat daar grasland is en melkvee. In het meest ongunstige geval, waarbij de diëten niet duurzamer zijn geworden en de productiviteit van het land met $30 \%$ is afgenomen (zie eerdere aannames), dan is $0.18 / 0.7=0.26$ hectare per persoon nodig. Dan kan met maximale sturing slechts $25 \%$ van de voedselproductie uit Noord-Brabant zelf afkomstig zijn. Daar komt nog bij dat niet alle producten die we consumeren in Nederland of in Noordwest Europa verbouwd kunnen worden.

Als de bandbreedte van 0.11 tot 0.26 hectare per persoon per jaar wordt toegepast op geheel Noordwest Europa, dan blijkt er genoeg land te zijn om een groot deel van de voedselproductie in dat gebied te realiseren. Ook daarbij dient rekening te worden gehouden met het feit dat een groot aandeel van de landbouwgrond grasland is en dat niet alle gewassen hier verbouwd kunnen worden. Zie Tabel 6.

\section{Tabel 6 Hoeveelheid agrarisch land per persoon.}

\begin{tabular}{|c|c|c|c|}
\hline & $\begin{array}{c}\text { Areaal } 2016 \\
(* 1000 \text { ha })\end{array}$ & Bevolking $2016(\mathrm{mln})$ & Agr land per persoon (ha/pp) \\
\hline België & 1335 & 11.4 & 0.12 \\
\hline Frankrijk & 28714 & 64.7 & 0.44 \\
\hline Duitsland & 16692 & 82.2 & 0.20 \\
\hline Ierland & 4449 & 4.7 & 0.95 \\
\hline Luxemburg & 131 & 0.6 & 0.23 \\
\hline Nederland & 1808 & 17.0 & 0.11 \\
\hline Totaal & 53129 & 180.5 & 0.29 \\
\hline \multirow[t]{2}{*}{ Noord Brabant } & 232 & 2.5 & 0.09 \\
\hline & $\begin{array}{c}\text { Areaal } 2040 \\
(* 1000 \text { ha) }\end{array}$ & Bevolking $2040(\mathrm{~m} / \mathrm{n})$ & Agr land per capita (ha/pp) \\
\hline België & 1233 & 12.5 & 0.10 \\
\hline Frankrijk & 26512 & 70.6 & 0.38 \\
\hline Duitsland & 15412 & 79.2 & 0.19 \\
\hline Ierland & 4108 & 5.8 & 0.71 \\
\hline Luxemburg & 121 & 0.8 & 0.15 \\
\hline Nederland & 1669 & 17.5 & 0.10 \\
\hline Totaal & 49054 & 186.4 & 0.26 \\
\hline Noord Brabant & 170 & 2.7 & 0.06 \\
\hline
\end{tabular}




\subsubsection{Samenvatting}

In 2019 maakte een groep internationale wetenschappers het planetary health diet: een referentie voedingspatroon van een gezond én duurzaam menu. Duurzaam betekent hier binnen de grenzen van het mondiale ecosysteem. Dit menu bestaat voor de helft uit groenten en fruit, de andere helft bestaat voornamelijk uit volkorengranen, plantaardige eiwitten, onverzadigde plantaardige olie, en een bescheiden hoeveelheid melkproducten en vlees (EAT Lancet, 2019). Meer plantaardige voeding is ook het advies van de Nederlandse Gezondheidsraad en diverse andere studies naar duurzame voedingspatronen. De 'eiwittransitie' en coalities als Green Protein Alliance spelen daarop in, evenals het landelijke Preventie Akkoord met daarin o.a. afspraken over gezonde voeding. Inspelen op zo'n toekomstig voedingspatroon, in combinatie met het fors reduceren van voedselverspilling, vergt echter naast een landbouwbeleid ook een voedselbeleid.

Om inzicht te krijgen in de mogelijkheden voor zelfvoorziening en circulariteit en de beschikbaarheid van voedsel is in hoofdstuk 6 een globale berekening gemaakt over productie en de in- en uitvoer van producten en grondstoffen. Het bepalen van de mogelijkheden voor zelfvoorziening op de schaal van Brabant of Noordwest Europa is niet eenvoudig. In de eerste plaats dienen productie en consumptie in evenwicht te zijn, waarbij export en import over de gebiedsgrenzen wordt uitgesloten. Dat levert voor een heel aantal producten al een probleem op, omdat de bevolking zowel in Brabant als in NWE ook producten consumeert die niet in deze regio's worden geproduceerd (zoals koffie, harde tarwe, tropisch fruit, rijst). Het uitsluiten van die producten leidt tot een drastische aanpassing van het consumptiepatroon. Voor de overige producten zou NWE redelijkerwijs zelfvoorzienend kunnen zijn, zeker als de consumptie en productie zou verschuiven van dierlijk naar plantaardig eiwit. In theorie is het mogelijk om ongeveer $80 \%$ van de voedselproductie in Noordwest Europa te realiseren. Daarin zit dan ook een verschuiving van diervoeders die meer bestaan uit reststromen uit de voedingsmiddelensector.

In Brabant is te weinig grond beschikbaar om aan de vraag te kunnen voldoen, omdat Brabant heel dicht bevolkt is. Een ander, niet onbelangrijk aspect aan zelfvoorziening is de sociaaleconomische kant: rekensommen laten theoretisch zien wat mogelijk is, maar daadwerkelijke realisatie vraagt een (stevig) ingrijpen in de markt (import, export), in de vrijheid van ondernemers en de keuzevrijheid van consumenten. Daarnaast is de governance een lastig vraagstuk: een provinciebestuur heeft nauwelijks of geen invloed, al zeker niet op het voedingspatroon van haar inwoners, en NWE is geen bestuurlijke eenheid. 


\section{$7 \quad$ Aandachtspunten bij een visie over landbouw, voedsel en leefomgeving}

De informatie in de vorige hoofdstukken laat een aantal dingen zien: Brabant is een belangrijke provincie voor agrofood in Nederland en in Noordwest Europa en omvat zowel toeleveranciers (bijv. machinebouw), agrarische productie als verwerking, handel en -uiteraard-consumptie. Het landbouwvoedselsysteem is echter veel groter dan de provincie Noord-Brabant, vanwege de grote internationale verwevenheid en export oriëntatie. De huidige voedselproductie en -consumptiepatronen zijn sterk gerelateerd aan een aantal urgente duurzaamheidsopgaven op het gebied van gezondheid en welzijn van mens, dier en planeet en leiden tot grote maatschappelijke kosten. De ontwikkeling van het landbouw-voedselsysteem botst in toenemende mate met de groeiende verstedelijking in Noordwest Europa en vooral ook met een aantal ecologische en gezondheidsgrenzen. Deze botsing vindt ook plaats in de provincie Brabant en vraagt ook op provinciaal niveau om visie en effectief beleid.

Het eerste aandachtspunt voor deze visie is dat er keuzes gemaakt moeten worden. Niet alles kan (overal): de fysieke ruimte is beperkt, en dat geldt ook voor milieuruimte (denk aan de stikstofemissies). Door klimaatverandering zal ook in toenemende mate competitie om (zoet) water plaatsvinden. Als verstedelijking, economische ontwikkeling, infrastructuur, energieproductie op land en de ontwikkeling van natuur (zowel de realisatie van het Ondernemende Natuurnetwerk Brabant als uitbreiding van natuur t.b.v. klimaatdoelstellingen) zich voortzetten, zal dit een fors beslag leggen op landbouwgrond. De landbouw zal zich in deze context verder intensiveren in de competitie om schaarse (steeds duurdere) grond en arbeid, in lijn met de ontwikkeling van de afgelopen decennia. En dat terwijl productiviteit van grondgebonden landbouw door klimaatverandering, zeker op de droogtegevoelige zandgronden in Brabant, onder druk staat.

Dit vraagt dus keuzes, ook op provinciaal niveau. De belangrijkste keus is het type beleid: kiest de provincie (en ook andere overheden) voor de traditionele lijn, waarin vooral randvoorwaarden worden gesteld aan economische activiteiten om schadelijke neveneffecten tegen te gaan? Dat betekent vaak dat enerzijds de landbouw aanvullende duurzaamheidseisen krijgt opgelegd, maar tegelijk in toenemende mate geconfronteerd wordt met hogere grondprijzen. Deze aanpak richt zich vaak op enkelvoudige problemen: waterkwaliteit, stikstof, energie, en is daardoor vaak reactief.

Het alternatief is een proactief, systeemgericht transitiebeleid, waarbij de uitdagingen van de toekomst meer integraal worden aangepakt. Daarbij worden maatschappelijke opgaven, in lijn met 'opgavegericht innovatiebeleid' (zie hst 4) in samenhang bekeken vanuit een lange termijn perspectief en worden niet alleen de negatieve uitkomsten aangepakt, maar juist de onderliggende oorzaken. Zo'n transitiegericht beleid vraagt dus ook om keuzes voor de toekomst: transities leiden onmiskenbaar tot botsende belangen waarbij economie soms moet worden afgewogen tegen ecologie of sociale waarden als gezondheid. Zie ook de X-curve in paragraaf 4.3 met opschalen én uitfaseren. Dat betekent dus ook dat gevestigde belangen niet persé leidend zijn bij beleidsontwikkeling. Dat is politiek-bestuurlijk geen eenvoudige opgave. Daartegenover staat dat de synergie tussen thema's kan worden benut; bijvoorbeeld stevig inzetten op het uitbreiden van natuur, natuur-inclusieve landbouw en vergroening in steden draagt positief bij aan biodiversiteit, klimaatdoelstellingen, reductie van emissies als stikstof, (in sommige gevallen) het watervasthoudend vermogen van de bodem, en een gezonde leefomgeving. Hetzelfde geldt voor de strategische keuze voor het versterken van de circulariteit van het landbouwvoedselsysteem; ook daar zouden synergiën met maatschappelijke opgaven kunnen worden benut maar is ook duidelijk sprake van trade-offs.

Een belangrijk aandachtspunt is dat het provinciebestuur beperkt invloed heeft op het landbouwvoedselsysteem. Dat betekent dus dat de provincie zich dus met name moet richten op de zaken waar ze wel invloed op heeft, zoals ruimtelijk beleid, milieubeleid en regionaal innovatiebeleid. Verder is het vooral van belang om samenwerking te zoeken, bijv. op landbouwbeleid met het ministerie van LNV en de EU. De provincie zou bijvoorbeeld mee vorm kunnen geven en ruimte kunnen bieden aan (beleids)experimenten van hogere overheden om (onderdelen van) het landbouwvoedselsysteem te vernieuwen of te experimenteren met het vergoeden van ecosysteemdiensten aan boeren. 
Tegelijk is het belangrijk dat de provincie zich bewust is van allerlei afwentelingseffecten, naar beleidsterreinen waar ze niet over gaat en ook naar andere regio's. Zo kan de provincie actief sturen op de provinciale voedselproductie via ruimtelijk beleid en milieubeleid, maar niet of nauwelijks op de voedselconsumptie van Brabanders en al helemaal niet op buitenlandse consumenten van exportproducten vanuit Brabant. Als de vleesconsumptie gelijk blijft, zou het verkleinen van de Brabantse veehouderij mogelijk bij kunnen dragen aan de oplossing van een aantal Brabantse knelpunten, maar tegelijk leiden tot een verplaatsing van deze productie naar andere regio's/landen. Een voedselbeleid, dat nu in de EU Farm to Fork strategie wordt voorgesteld, naast een landbouwbeleid, is meer een vraagstuk van EU en de landelijke politiek, zie bijv het Preventie Akkoord. De provincie kan wel verkennen op welke wijze ze zou willen bijdragen aan 1) het versterken van de verbinding boer-burger en de waardering voor voedsel (producenten), bijvoorbeeld via korte ketens en 2) het stimuleren van voedselvaardigheden, bijvoorbeeld via onderwijs.

Een gebiedsgerichte aanpak sluit aan op de bevoegdheden en rol van de provincie: veel beleidsterreinen hebben een sterk ruimtelijke, plaatsgebonden component en komen dus fysiek samen in de regio. Het is belangrijk dat de provincie dan wel goed nadenkt over de schaal van de regio: bestuurskundige grenzen (gemeentes, waterschappen, provincie) komen niet altijd overeen met bijv. de grenzen van een landbouwgebied of een stroomgebied, en zoals gezegd is het voedselsysteem veel groter dan de provincie. Wellicht zijn sommige knelpunten op gemeentelijk of waterschapsniveau aan te pakken, maar zal voor andere uitdagingen juist provinciaal of provincie-overstijgend beleid gewerkt moeten worden. Deze verschillende schaalniveaus en bestuurlijke grenzen maken de beleidsontwikkeling niet eenvoudiger. Ook het vraagstuk van governance speelt daarbij een cruciale rol. De provincie zou daar wel een regierol kunnen vervullen en de integraliteit bewaken.

Alles overwegend is het een uitdagende tijd waarin grote transitieopgaven zorgen voor grote dynamiek in onze agrofood sector. Dit vraagt meer dan ooit om leiderschap voor het minimaliseren van trade-offs en het maximaliseren van synergiën tussen de verschillende sectoren en disciplines. De landbouw en voedselsector is als geen andere in staat om de verschillende maatschappelijke functies te combineren; vanuit de sterke positie van Brabant biedt dit veel kansen. Daarnaast is en blijft voedsel voor iedereen letterlijk van levensbelang. 


\section{Literatuur}

Actieprogramma Plantgezondheid 2020: https://www.akkerwijzer.nl/artikel/128454-actieplanplantgezondheid-voor-gezonde-bodem-en-rendabele-akkerbouw/

Agrimatie. (2017). De keten van groenten en fruit. Retrieved 22 April 2020, from https://agrofoodportal.com/ThemaResultaat.aspx?subpubID =2232\&themaID =3577

Agrifoodmonitor 2020. Waardering van de Agri \& Food-sector van 2012 tot nu Marleen Onwezen, Emily Bouwman, Danny Taufik en Joris Galama. Wageningen Economic Research. https://www.wur.nl/en/show/Agrifoodmonitor-2020-1.htm

Baltussen, W., de Adelhart Toorop, R., de Blaeij, A., de Groot Ruiz, A., Janssens, B., Logatcheva, K., Ponsioen, T. (2017). Maatschappelijke effecten van voedsel: Een verkenning van een nieuwe methodiek. (Wageningen Economic Research rapport; No. 2017-022). https://doi.org/10.18174/408313

Bennett, M. K. (1941). Wheat in National Diets. Wheat Studies, 37-76. https://doi.org/10.22004/ag.econ.142802

Boer, I.J.M. De \& Ittersum, M.K. Van (2018). Circularity in Agricultural Production. Wageningen University \& Research, Wageningen.

Brabant: Mozaïek van klimaatopgaven. (2020). Retrieved July 14, 2020, from https://climadapserv.maps.arcgis.com/apps/Cascade/index.html?appid=9858bf99076b4f4bbad10 a92d1c7fdb5

Brabant.nl, website provincie Brabant, over natuurnetwerk Brabant, geraadpleegd 10 feb 2021.

Brabant.nl, http://www.brabantinzicht.nl/toestand-natuur-water-en-milieu/water/, geraadpleegd 19 feb 2021

Brabant.nl, https://www.brabant.nl/onderwerpen/internationaal/internationale-samenwerking , geraadpleegd 22 mrt 2021.

Brabantse Ontwikkelaanpak Stikstof 1.0, uitvoeringsagenda 2020-2023.

file://C:/Users/PrF/Downloads/Brabantse\%20Ontwikkelaanpak\%20Stikstof\%20(BOS)\%201.0.pdf

Geraadpleegd 8 Feb 2021.

Brabantse Ontwikkel Maatschappij, 2020. An in-depth overview of the agrifood sector in Brabant. https://www.bom.nl/foreign-investments/downloads/36/def-bom-agrifood-compleet-Ir.pdf

Brabantmagazine. (2018). Brabant Magazine special Water: Droogte. Retrieved July 14, 2020, from https://www.brabantmagazine.nl/magazine/2018waterspecial/droogte/

CBS, Statistics Netherlands. (2020). Slight decline in arable crop area. Retrieved July 14, 2020, from https://www.cbs.nl/en-gb/news/2020/27/slight-decline-in-arable-crop-area

CBS (2018), Statline, Bestedingen; consumptie huishoudens, Den Haag/Heerlen: Centraal Bureau voor de Statistiek

CBS (2018b). Bodemgebruik; uitgebreide gebruiksvorm, per gemeente. Retrieved July 14, 2020, from https://opendata.cbs.nl/statline/

CEPII. (2017, March). Nutrition Transition and the Structure of Global Food Demand. http://www.cepii.fr/PDF_PUB/wp/2017/wp2017-05.pdf

Delaney, A., Evans, T., McGreevy, J., Blekking, J., Schlachter, T., Korhonen-Kurki, K., Tamás, P. A., Crane, T. A., Eakin, H., Förch, W., Jones, L., Nelson, D. R., Oberlack, C., Purdon, M., \& Rist, S. (2018). Governance of food systems across scales in times of social-ecological change: a review of indicators. Food Security, 10(2), 287-310.

Doomen, R., Puhe, L., \& Van Leeuwen, B. (2019). Food forest business models in the Netherlands Project report. Retrieved from http://www.natuurverdubbelaars.nl/wpcontent/uploads/2019/08/0000-Food-Forests-business-models-in-the-Netherlands-Report-Finalversion.pdf

European Commission, official website. Retrieved May 15, 2020, from https://ec.europa.eu/

European Commission. (2020a). Farm to fork strategy - for a fair, healthy and environmentallyfriendly food system. Food Safety. Retrieved July 14, 2020, from https://ec.europa.eu/food/farm2fork_en

Eurostat. (2019). Agri-environmental indicator-livestock patterns. Retrieved July 14, 2020, from https://ec.europa.eu/eurostat/statistics-explained/index.php/Agri-environmental_indicator__livestock_patterns 
Eurostat. (2016). Degree of urbanisation (DEGURBA). (2016). Retrieved July 14, 2020, from https://ec.europa.eu/eurostat/web/degree-of-urbanisation/background

Eurostat. (2015). Land cover overview by NUTS 2 regions. Retrieved July 14, 2020, from https://ec.europa.eu/eurostat/web/lucas/data/database

FAO. (2006). Food security. https://www.fao.org/fileadmin/templates/faoitaly/documents/pdf/pdf_Food_Security_Cocept_Note .pdf

FAO. (2020). Netherlands. Retrieved July 14, 2020, from https://www.fao.org/countryprofiles/index/en/?iso3=NLD

Food and Agriculture Organization of the United Nations. (1997). FAOSTAT statistical database. [Rome]:FAO, 1997.

GAIN (2019). The 2019 Dutch Food Processing Ingredients Report. https://gain.fas.usda.gov/Recent\%20GAIN\%20Publications/Food\%20Processing\%20Ingredients_T he\%20Hague_Netherlands_4-3-2019.pdf

Gehlhar, M. and A. Regmi (2005) 'Factors Shaping Global Food Markets', pp. 5-18 in M. Gehlhar and A. Regmi (ed.) New Directions in Global Food Markets, Washington, D.C.: United States Department of Agriculture.

GFK, 2018: https://b-open.nl/wp-content/uploads/2018/10/Persbericht-Dossier-Duurzaam-2018_9oktober-2018.pdf

Gies, T.J.A., Naeff, H.S.D. (2019) Actualisatie leegstand agrarisch vastgoed Noord-Brabant. Ontwikkeling aard en omvang agrarisch vastgoed tussen 2012 en 2017 in provincie NoordBrabant. Wageningen Environmental Research.

Government of the Netherlands. (2020). Policy on nature and biodiversity. Information from the Government of The Netherlands | Government.nl. Retrieved July 14, 2020, from https://www.government.nl/topics/nature-and-biodiversity/policy-on-nature-and-biodiversity

Governament of the Nehterlands. (2019). Environmental Data Compendium. Retrieved July 14, 2020, from https://www.clo.nl/en

Groen Ontwikkelfonds Brabant. (2020). Retrieved July 14, 2020, from https://www.groenontwikkelfondsbrabant.nl/

ING, \& Geijer, T. (2020). Horeca groeit in een gematigder tempo in 2020. Retrieved 9 April 2020, from https://www.ing.nl/zakelijk/kennis-over-de-economie/uw-sector/outlook/horeca.html

Interreg Europe. (2020). Retrieved July 14, 2020, from https://www.interregeurope.eu/

IPBES (2019). Global Assessment Report on Biodiversity and Ecosystem Services https://ipbes.net/global-assessment.

IPCC. (2019). Science and impacts. C2ES.

IRI. (2018). TOP CATEGORIES PERFORMANCE OVERVIEW IN KEY EUROPEAN MARKETS. Retrieved from https://www.iriworldwide.com/IRI/media/IRI-Clients/International/Top-Categories-SpecialReport-2018.pdf

Kaag, S., Schouten, C. (2019). Kamerbrief Op weg naar een wereld zonder honger in 2030: de Nederlandse inzet https://www.rijksoverheid.nl/documenten/kamerstukken/2019/06/06/op-wegnaar-een-wereld-zonder-honger-in-2030-de-nederlandse-inzet

Kang, J., Jun, J., \& Arendt, S. W. (2015). Understanding customers' healthy food choices at casual dining restaurants: Using the Value-Attitude-Behavior model. International Journal of Hospitality Management, 48, 12-21.

Kempenaar et al., 2019: https://research.wur.nl/en/publications/op-naar-precisielandbouw-20eindrapport-pps-pl20-2015-2019-topsec

Kennedy, E; Gladek, E.; Roemers, G. (2018). Using systems thinking to transform society. https://www.metabolic.nl/publications/using-systems-thinking-to-transform-society/

Kernebeek, H.R.J. van; Oosting, S.J.; Van Ittersum, M.K.; Bikker,P. en de Boer, I.J.M. (2016) Saving land to feed a growing population: consequences for consumption of crop and livestock products. International Journal of Life Cycle Assessment 21 (2016): 677 - 687.

Klimaatadaptatie Provincie Noord-Brabant. (2020). Klimaatopgaven - Klimaatadaptatie Provincie Noord-Brabant. Klimaatadaptatie Provincie Noord-Brabant. Retrieved from https://www.klimaatadaptatiebrabant.nl/klimaatopgaven

KNMI, 2020. https://www.knmi.nl/over-het-knmi/nieuws/toename-neerslagtekort-en-verdamping-in-voorjaar. Data van mei 2020.

Lagas, P., Kuiper, R., van Dongen, F., van Rijn, F., \& van Amsterdam, H. (2014). Regional Quality of Living in Europe (1271). PBL. https://www.pbl.nl/sites/default/files/downloads/PBL-2014Regional-Quality-of-Living-in-Europe-1271.pdf 
Lallukka, T., Laaksonen, M., Rahkonen, O., Roos, E., \& Lahelma, E. (2006). Multiple socio-economic circumstances and healthy food habits. European Journal of Clinical Nutrition, 61(6), 701-710.

Leenstra, F., Vellinga, T. \& Bremmer, B. (2017). Kringlooptoets: sluiten van de nutriëntenkringloop op het niveau van Noordwest Europa. Wageningen Livestock Research, rapport 1019, Wageningen.

Logatcheva, K. (2020). Monitor Duurzaam Voedsel 2019: Consumentenbestedingen. Retrieved from https://edepot.wur.nl/532565

Loorbach, D, 2012. To Transition, governance panarchy in the new transformation. Inaugural lectore. Erasmus University Rotterdam. http://drift.eur.nl/publication/transition-governance-panarchynew-transformation/

Maani, K. \& Cavana, R. (2007). Systems Thinking, System Dynamics (2nd Edition) 2nd Edition. ISBN13: 9781877371035

Marketline. (2019, October). The Netherlands In-depth PESTLE insights. https://advantagemarketline-com.has.idm.oclc.org/Analysis/details/country-analysis-report-netherlands-in-depthpestle-insights-25950

Martinez, S., Hand, M., Da Pra, M., Pollack, S., Ralston, K., Smith, T., ... Newman, C. (2010). Local food systems: Concepts, Impacts, and issues (97).

Meadows D. (2001) Leverage points: Places to intervene in a system. Hartland: The Sustainability Institute

Ministerie van Volksgezondheid, Welzijn en Sport. (2018). Nationaal Preventieakkoord.

Noord-Brabant. (2020, July 13). Brabant.nl. Retrieved July 14, 2020, from https://www.brabant.nl/

OESD, 2021. Making better policies for food systems. Trade and Agriculture Directorate, Koen Deconinck et al. Organisation for Economic Co-operation and Development.

PBL (2019), Dagelijkse kost. Hoe overheden, bedrijven en consumenten kunnen bijdragen aan een duurzaam voedselsysteem, Den Haag: Planbureau voor de Leefomgeving.

PBL (2020) https://www.pbl.nl/publicaties/inzichten-uit-mondiale-milieuverkenningen-lessen-voornederland

Pharo P., Oppenheim, J., Laderchi, C. R., and Benson, S., 2019. Global food and land use coalition. Growing better: Ten Critical Transitions to Transform Food and Land Use. https://www.foodandlandusecoalition.org/global-report/

Planbureau voor de Leefomgeving. (2014). De toekomst is nú: Balans van de Leefomgeving. https://themasites.pbl.nl/balansvandeleefomgeving/wp-content/uploads/PBL_2014_Balans-vande-Leefomgeving-2014_1308.pdf

Poelman, M. (2016), 'De stad als verleidelijke voedselomgeving', Agora 3: 10-13.

Pouwels, R., Henkens, R. (2020). Naar een hoger doelbereik van de Vogel- en Habitatrichtlijn in Nederland. Een analyse van de resterende opgave na 2027 voor het bereiken van een gunstige staat van instandhouding van alle habitattypen en VHR-soorten. Wageningen Environmental Research.

Provincie NB. (2017). De bevolkings- en woningbehoefteprognose Noord-Brabant. https://bevolkingsprognose.brabant.nl

Provincie Noord-Brabant. (2017a). Brabant Databank. Brabant Databank. https://brabant.databank.nl/jive/jive?presel_code=h1_3 Province Noord-Brabant. (2014).

Structuurvisie ruimtelijke ordening. Retrieved July 14, 2020, from https://www.brabant.nl/onderwerpen/ruimtelijke-ontwikkeling/ruimtelijk-beleid/structuurvisie

Rathenau instituut (2019). Missiegedreven innovatiebeleid: wat, hoe, waarom? Website https://www.rathenau. $\mathrm{nl} / \mathrm{nl} /$ vitale-kennisecosystemen/missiegedreven-innovatiebeleid-wat-hoewaarom (retrieved April 2020)Rathenau instituut, 2020. https://www.rathenau.nl/nl/vitalekennisecosystemen/missiegedreven-innovatiebeleid-wat-hoe-waarom

Rathenau, 2020. https://www.rathenau.nl/nl/berichten-aan-het-parlement/maak-werk-vanopgavegericht-innovatiebeleid. Dec 2020.

RIVM (2016) Food consumption in the Netherlands and its determinants. https://www.rivm.nl/bibliotheek/rapporten/2016-0195.pdf

RIVM (2016). Voedselconsumptiepeiling. Retrieved July 14, 2020, from https://www.wateetnederland.nl/

RIVM (2017). Veehouderij en gezondheid omwonenden (VGO). Retrieved July 14, 2020, from https://www.rivm.nl/veehouderij-en-gezondheid/onderzoek-veehouderij-en-gezondheidomwonenden-vgo

RIVM (2018). Quickscan mogelijke impact Nationaal Preventieakkoord.

RIVM (2018b), Factsheet Voedselconsumptie 2012-2016. Wat, waar, wanneer. Bilthoven: RIVM. 
RIVM, 2020. Nationaal Kompas Volksgezondheid, https://www.volksgezondheidenzorg.info/onderwerp/voeding/cijfers-context/gevolgen\# nodeziektelast-voeding. Datum van publicatie: 13-10-2020.

ROS 2020: https://www.linkedin.com/pulse/de-bodem-echt-bereikt-gerard-ros/

Stec-groep. (2018). Prognose bedrijventerreinen en kantoren Noord-Brabant. Retrieved from https://userfiles. mailswitch.nl/c/686466078377e314473da3253f2b52f9/1775d7862a74bb0d751f5d0cb88e22af0ffd.pdf

Terluin, I.J.; Kamphuis, B.M.; Oudendag, D.A.; van Leeuwen, M.G.A. (2013) Voedselvoorziening in Nederland onder buitengewone crisisomstandigheden. Wageningen Economic Research, Den Haag

UNEP (2016)Food Systems and Natural Resources. A Report of the Working Group on Food Systems of the International Resource Panel. Westhoek, H, Ingram J., Van Berkum, S., Özay, L., and Hajer M

United Nations, Department of Economic and Social Affairs, Population Division (2019). World Urbanization Prospects: The 2018 Revision (ST/ESA/SER.A/420). New York: United Nations.

Van Berkum, S., Dengerink, J., \& Ruben, R. (2018). The food systems approach: sustainable solutions for a sufficient supply of healthy food (No. 2018-064). Wageningen Economic Research.

Velthof, G. L., Lesschen, J. P., Webb, J., Pietrzak, S., Miatkowski, Z., Pinto, M., \& Oenema, O. (2014). The impact of the Nitrates Directive on nitrogen emissions from agriculture in the EU-27 during 2000-2008. Science of the Total Environment, 468, 1225-1233.

Venema, G. S., Dolman, M. A., Smit, A. B., Jukema, G. D., Wisman, J. H., \& Jager, J. H. (2019). Barometer Duurzame landbouw Noord-Brabant. Wageningen Economic Research.

Venema, G. et al, Wageningen Economic Research, nog te publiceren.

Verboom et al., 2010: https://link.springer.com/article/10.1007/s10980-010-9497-7

Vijn, M., Vermeij, I, Dawson, A., Wolf, P.L. de \& Voort, M.P.J. van der (2019). Welke mogelijkheden zijn er om meer diervoeders in Nederland te produceren? Verkenning van de mogelijkheden tot het verhogen van de productie van diervoeders uit reststromen in Nederland op basis van beschikbare kennis en data. Wageningen Plant Research, rapport WPR-796, Wageningen.

Visseren-Hamakers, I.J. (2020). The 18th Sustainable Development Goal. Earth System Governance. https://doi.org/10.1016/j.esg.2020.100047

Wallace, R.G., Bergmann, L., Kock, R., Gilbert, M., Hogerwerf, L., Wallace, R., Holmberg, M. (2015). The dawn of Structural One Health: A new science tracking disease emergence along circuits of capital. Social Science \& Medicine 129, 68-77. https://doi.org/10.1016/j.socscimed.2014.09.047

Warde, A., \& Martens, L. (2000). Eating Out: Social Differentiation, Consumption and Pleasure.

Willett, W., Rockström, J., Loken, B., Springmann, M., Lang, T., Vermeulen, S., ... \& Jonell, M. (2019). Food in the Anthropocene: the EAT-Lancet Commission on healthy diets from sustainable food systems. The Lancet, 393(10170), 447-492.

Wolf, P.L. de, Verstand, D., Poppe, K.J. \& Vellinga, T. (2019). Mest en Metropolen; Een bijdrage aan de discussie over oplossingsrichtingen voor het sluiten van kringlopen. Wageningen Research rapport 791, Lelystad.

WRR. (2014). Naar een voedselbeleid. Amsterdam University Press.

WUR (2017) Voedsel Economisch Bericht. Wageningen University and Research. www.agrimatie.nl bezocht op 24-7-2018. 


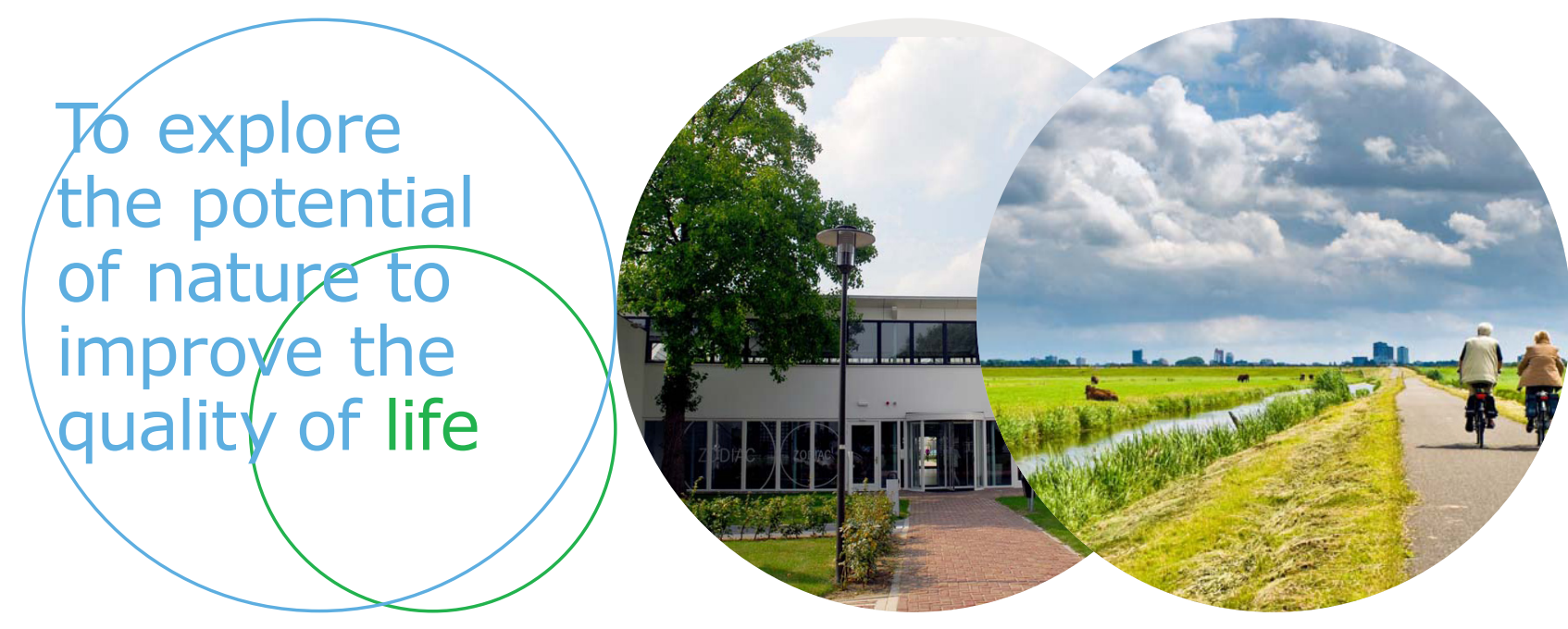

Wageningen Livestock Research Postbus 338

$6700 \mathrm{AH}$ Wageningen

T 0317483953

E info.livestockresearch@wur.nl www.wur.nl/livestock-research
Wageningen Livestock Research ontwikkelt kennis voor een zorgvuldige en renderende veehouderij, vertaalt deze naar praktijkgerichte oplossingen en innovaties, en zorgt voor doorstroming van deze kennis. Onze wetenschappelijke kennis op het gebied van veehouderijsystemen en van voeding, genetica, welzijn en milieu-impact van landbouwhuisdieren integreren we, samen met onze klanten, tot veehouderijconcepten voor de $21 \mathrm{e}$ eeuw.

De missie van Wageningen University \& Research is 'To explore the potential of nature to improve the quality of life'. Binnen Wageningen University \& Research bundelen 9 gespecialiseerde onderzoeksinstituten van Stichting Wageningen Research en Wageningen University hun krachten om bij te dragen aan de oplossing van belangrijke vragen in het domein van gezonde voeding en leefomgeving. Met ongeveer 30 vestigingen, 6.500 medewerkers en 10.000 studenten behoort Wageningen University \& Research wereldwijd tot de aansprekende kennisinstellingen binnen haar domein. De integrale benadering van de vraagstukken en de samenwerking tussen verschillende disciplines vormen het hart van de unieke Wageningen aanpak. 